DOE/NV/11508-29

UC-703

$$
\text { DRI- } 45 / 59
$$

\title{
NUMERICAL EVALUATION OF MONOFIL AND SUBTLE-LAYERED EVAPOTRANSPIRATION (ET) LANDFILL CAPS
}

\author{
prepared by \\ MAR 161998 \\ OSTI \\ Glenn V. Wilson, Maren Henley, and Rob Valceschini
}

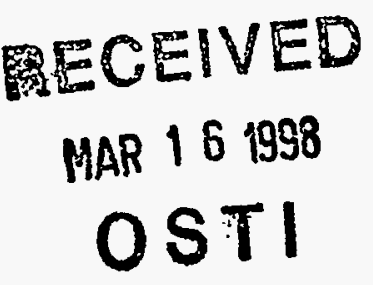

submitted to

Nevada Operations Office

U.S. Department of Energy

January 1998

MASTER

DISTRIBUTION OF THIS DOCUAGENT IS UNLIMITED

Publication No. 45159 
This report was prepared as an account of work sponsored by the United States Government. Neither the United States nor the United States Department of Energy, nor any of their employees, makes any warranty, express or implied, or assumes any legal liability or responsibility for the accuracy, completeness or usefulness of any information, apparatus, product or process disclosed, or represents that its use would not infringe privately owned rights. Reference herein to any specific commercial product, process, or service by trade name, mark, manufacturer, or otherwise, does not necessarily constitute or imply its endorsement, recommendation, or favoring by the United States Government or any agency thereof. The views and opinions of authors expressed herein do not necessarily state or reflect those of the United States Government or any agency thereof.

This report has been reproduced directly from the best available copy.

Available to DOE and DOE contractors from the Office of Scientific and Technical Information, P.O. Box 62, Oak Ridge, TN 37831; prices available from (423) 576-8401.

Available to the public from the National Technical Information Service, U.S. Department of Commerce, 5285 Port Royal Rd., Springfield, VA 22161. 


\section{DISCLAIMER}

Portions of this document may be illegible electronic image products. Images are produced from the best available original document. 


\title{
NUMERICAL EVALUATION OF MONOFIL AND SUBTLE-LAYERED EVAPOTRANSPIRATION (ET) LANDFILL CAPS
}

\author{
prepared by \\ Glenn V. Wilson ${ }^{1}$, Maren Henley ${ }^{2}$, and Rob Valceschini ${ }^{3}$ \\ Water Resources Center \\ Desert Research Institute \\ University and Community College System of Nevada
}

Publication No. 45159

submitted to

Nevada Operations Office

U.S. Department of Energy

Las Vegas, Nevada

January 1998

The work upon which this report is based was supported by the U.S. Department of Energy under Contract \#DE-AC08-95NV11508.

${ }^{1}$ Associate Research Professor, Water Resources Center, Desert Research Institute

${ }^{2}$ DOE EPSCoR Young Scholar

${ }^{3}$ Research Associate, Dept. of Civil Engineering, University of Nevada Reno 


\section{EXECUTIVE SUMMARY}

The U.S. Department of Energy/Nevada Operations Office (DOE/NV) has identified the need to design a low-level waste (LLW) closure cap for the arid conditions at the Nevada Test Site (NTS). As a result of concerns for subsidence impacting the cover, DOE/NV redesigned the LLW cover from one containing a "hard" infiltration barrier that would likely fail, to a "soft" (ET) cover that is sufficiently deep to accommodate the hydrologic problems of subsidence. An ET cover is one that does not contain hydrologic barrier layers but relies on soil-water retention and sufficient thickness to store water until evapotranspiration (ET) can remove the moisture. Subtle layering within an ET cap using the native soil could be environmentally beneficial and cost effective.

One of the primary concerns with the monofil ET cover design is the lack of layering to disrupt vertical preferential flowpaths. However, the performance of engineered layers such as capillary barriers is not warranted for the hydrogeologic conditions of the NTS, and the long-term stability of such dramatically contrasting layers is highly questionable. An alternative that was investigated in this report is to incorporate layers with subtle differences in compaction and/or particle size distributions. Screening the borrow source material at the coarse sand $(<2 \mathrm{~mm})$ or fine-gravel $(<5$ $\mathrm{mm}$ ) sizes would not only provide material for constructing a desert armoring surface layer but would result in a thinner cover.

To evaluate this subtle layering design, physical and hydraulic properties of the borrow source material were analyzed and used in unsaturated flow simulations to evaluate various cap designs. The results of the particle size analysis showed that by the USDA soil classification scheme, the Area 3 material is a gravelly loamy sand with about $35 \%$ gravel size mass fractions. Compaction tests were run on the $<19 \mathrm{~mm},<5 \mathrm{~mm}$, and $<2 \mathrm{~mm}$ size fractions. The respective maximum dry bulk densities were $1.91,1.84$, and $1.84 \mathrm{~g} \mathrm{~cm}^{-3}$ and their associated optimum moisture contents were 11.5 , 12.5 , and $14.0 \%$ by weight, respectively. The saturated hydraulic conductivity, and water retention characteristics were determined on these three size fractions compacted to $83 \%$ and $90 \%$ maximum dry density, and on the 5 to $2 \mathrm{~mm}$ size fraction at the best achievable bulk density. A larger reduction in saturated hydraulic conductivity was achieved by differences in particle size fractions than by compaction. Differences in water retention characteristics were small between compaction and particle size fractions.

These data were incorporated into the computer model, HYDRUS-2D, to simulate infiltration through unsaturated soil for a $100 \mathrm{yr}-6$ hour storm event for various cover designs. If infiltration moves preferentially through only $5 \%$ of the cross-sectional area, the monofil cover would need to be $26 \%$ thicker on average to limit infiltration. However, if subtle layering is incorporated into the cover, the thickness could be reduced by 15 to $60 \%$ depending upon the number of layers and arrangement. This report recommends that a subtle-layered ET cover should consist of a surface armoring layer from 0 to $15 \mathrm{~cm}$ deep, and a loamy sand layer compacted to $90 \%$ maximum density at the 45 to $60 \mathrm{~cm}$ depth with the intermediate layer and base consisting of the original borrow source material compacted at only $83 \%$ maximum density. The thickness of the base layer, essentially the operational cover now in existence, would be determined by the thickness necessary to accommodate subsidence by providing the minimum standard for waste coverage. Simulations based upon this 
design for a year consisting of the maximum monthly rainfall recorded over a 30-year period on the NTS, applied as individual storm events at the first of each month, followed by the $100 \mathrm{yr}-6$ hour event the first day of the second year, showed that infiltration would be limited to less than $75 \mathrm{~cm}$. Subtle layers not only provide redundancy in protection to the thickness, they may also provide a reduction in risk to human health and the environment, and a reduction in overall life-cycle costs by facilitating savings in long-term monitoring requirements. 


\section{CONTENTS}

EXECUTIVE SUMMARY $\ldots \ldots \ldots \ldots \ldots \ldots \ldots \ldots \ldots \ldots \ldots \ldots \ldots \ldots \ldots \ldots \ldots$ ii

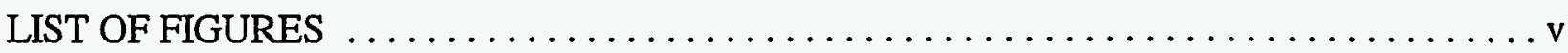

LIST OF TABLES $\ldots \ldots \ldots \ldots \ldots \ldots \ldots \ldots \ldots \ldots \ldots \ldots \ldots \ldots \ldots \ldots \ldots \ldots \ldots \ldots \ldots$ vi

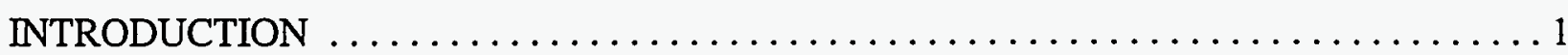

OBJECTIVES $\ldots \ldots \ldots \ldots \ldots \ldots \ldots \ldots \ldots \ldots \ldots \ldots \ldots \ldots \ldots \ldots \ldots \ldots$

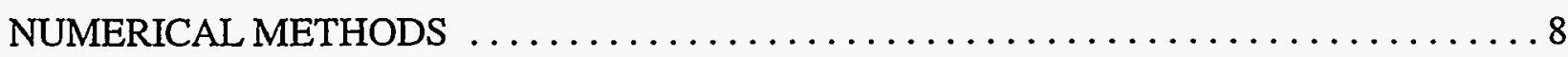

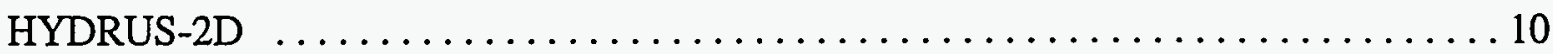

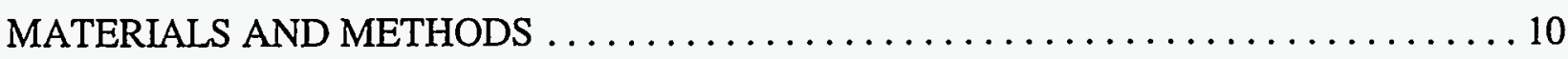

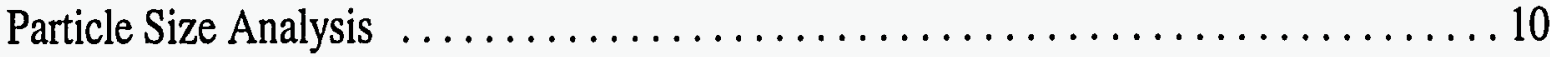

Modified Proctor Compaction Test $\ldots \ldots \ldots \ldots \ldots \ldots \ldots \ldots \ldots \ldots \ldots \ldots \ldots \ldots \ldots \ldots \ldots$

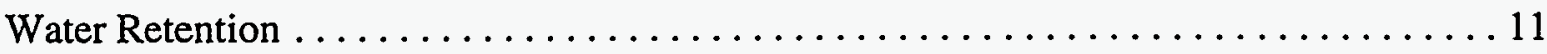

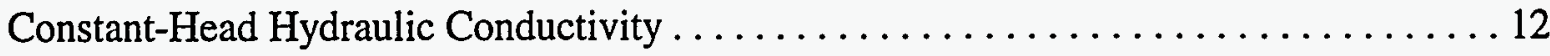

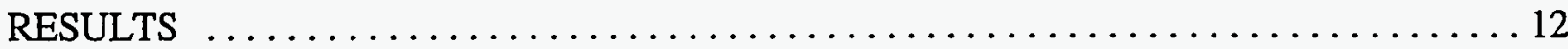

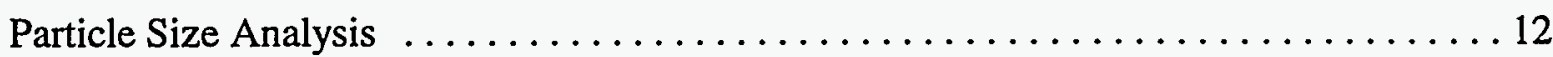

Modified Proctor Compaction Test .............................. 13

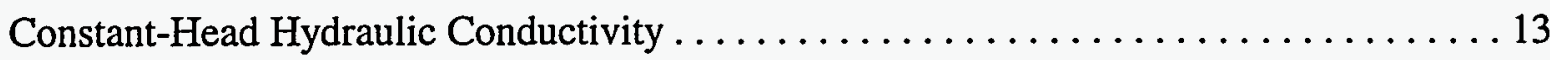

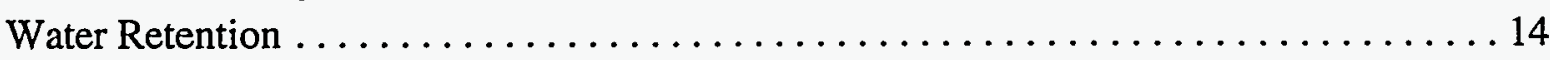

Cover Design Evaluations Using HYDRUS-2D $\ldots \ldots \ldots \ldots \ldots \ldots \ldots \ldots \ldots \ldots \ldots \ldots \ldots \ldots$

CONCLUSIONS AND RECOMMENDATIONS $\ldots \ldots \ldots \ldots \ldots \ldots \ldots \ldots \ldots \ldots \ldots \ldots \ldots$

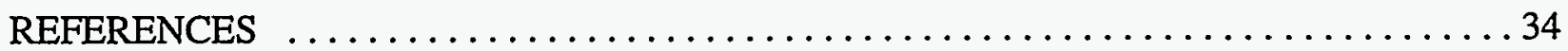

Appendix A: Particle Size Analysis Data

Appendix B: Modified Proctor Compaction Test Data

Appendix C: Saturated Hydraulic Conductivity Data

Appendix D: Water Retention Data 


\section{FIGURES}

1. Map of the NTS showing the Area 3 and 5 Radioactive Waste Management Sites (reprinted from Johnejack et al., 1995) ..........................

2. Diagram of an ET monofil cover design. $\ldots \ldots \ldots \ldots \ldots \ldots \ldots \ldots \ldots \ldots \ldots \ldots \ldots \ldots \ldots \ldots \ldots$

3. Diagram of a prescriptive RCRA Title $\mathrm{C}$ cover design $\ldots \ldots \ldots \ldots \ldots \ldots \ldots \ldots \ldots \ldots$

4. Spatial distribution of cumulative drainage from the bottom of an undisturbed sand block at (a) $4.5 \mathrm{~m}$ depth (Kinsall et al., 1997) and (b) $5.9 \mathrm{~m}$ depth (Wilson et al., 1997) ....................................... 4

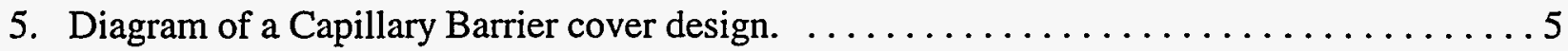

6. Illustration of hydrologic impacts of subsidence on covers with barrier layers $\ldots \ldots \ldots \ldots 6$

7. Diagram of a subtle-layered ET cover design $\ldots \ldots \ldots \ldots \ldots \ldots \ldots \ldots \ldots \ldots \ldots \ldots \ldots \ldots \ldots$

8. Mass fractions, expressed as percent by weight, of the particle sizes $\ldots \ldots \ldots \ldots \ldots 13$

9. Saturated hydraulic conductivity versus compacted bulk density for the $<19 \mathrm{~mm}$ (squares), $<5 \mathrm{~mm}$ (circles), $<2 \mathrm{~mm}$ (triangles), and 5 to $2 \mathrm{~mm}$

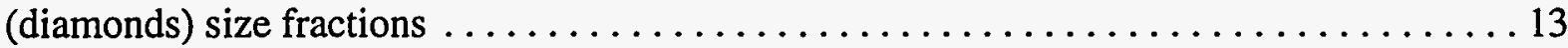

10. Water retention for samples compacted to $83 \%$ (triangles) and $90 \%$ (circles) maximum dry density for the size fractions: (a) $<19 \mathrm{~mm}$, (b) $<5 \mathrm{~mm}$, (c) $<2 \mathrm{~mm}$

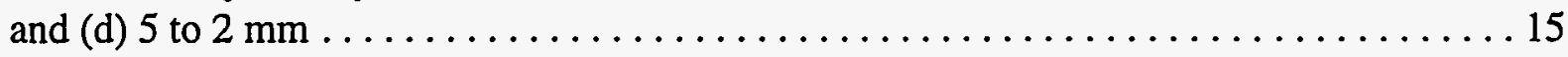

11. Material properties distributions for the six design scenarios indicated by color patterns $\ldots 18$

12. Volumetric water content distributions with time (hours) for 5 to $2 \mathrm{~mm}$, over $<5 \mathrm{~mm}$ size fraction compacted at $83 \%$ maximum density assuming uniform flow $\ldots \ldots 20$

13. Volumetric water content distributions with time (hours) for 5 to $2 \mathrm{~mm}$, over $<5 \mathrm{~mm}$ size fraction compacted at $83 \%$ maximum density assuming preferential flow through 5\% CSA

14. Volumetric water content distributions with time (hours) for 5 to $2 \mathrm{~mm}$, over layers of $<5 \mathrm{~mm}$ size fraction compacted at $90 \%$, and $83 \%$ maximum density, respectively,

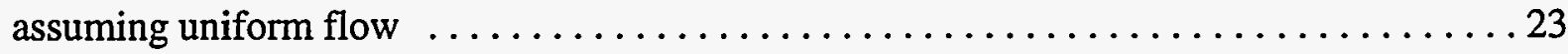

15. Volumetric water content distributions with time (hours) for 5 to $2 \mathrm{~mm}$, over layers of $<5 \mathrm{~mm}$ size fraction compacted at $90 \%$, and $83 \%$ maximum density, respectively, assuming preferential flow through 5\% CSA 
16. Volumetric water content distributions with time (hours) for 5 to $2 \mathrm{~mm}$, over layers of $<19 \mathrm{~mm}$ size fraction compacted at $83 \%, 90 \%$, and $83 \%$ maximum density, respectively, assuming uniform flow

17. Volumetric water content distributions with time (hours) for 5 to $2 \mathrm{~mm}$, over layers of $<5 \mathrm{~mm}$ size fraction compacted at $83 \%, 90 \%$, and $83 \%$ maximum density,

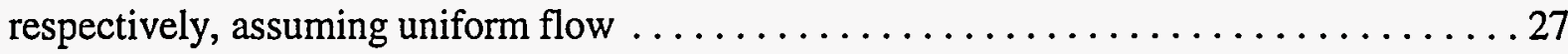

18. Volumetric water content distributions with time (hours) for 5 to $2 \mathrm{~mm}$, over layers of $<2 \mathrm{~m}$ size fraction compacted at $83 \%, 90 \%$, and $83 \%$ maximum density,

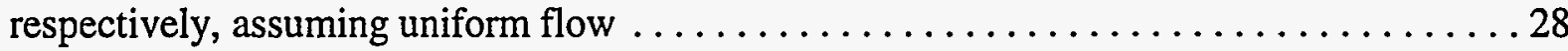

19. Volumetric water content distributions with time (hours) for 5 to $2 \mathrm{~mm}$, over layers of $<19 \mathrm{~mm}$ size fraction compacted at $83 \%, 90 \%$, and $83 \%$ maximum density, respectively, assuming preferential flow through $5 \%$ CSA . . . . . . . . . 29

20. Volumetric water content distributions with time (hours) for 5 to $2 \mathrm{~mm}$, over layers of $<5 \mathrm{~mm}$ size fraction compacted at $83 \%, 90 \%$, and $83 \%$ maximum density, respectively, assuming preferential flow through $5 \%$ CSA $\ldots \ldots \ldots \ldots \ldots 30$

21. Volumetric water content distributions with time (hours) for 5 to $2 \mathrm{~mm}$, over layers of $<2 \mathrm{~mm}$ size fraction compacted at $83 \%, 90 \%$, and $83 \%$ maximum density, respectively, assuming preferential flow through $5 \%$ CSA $\ldots \ldots \ldots \ldots \ldots 31$

22. Volumetric water content distributions with time (days) for 5 to $2 \mathrm{~mm}$, over layers of $<19 \mathrm{~mm}$ size fraction compacted at $83 \%,<2 \mathrm{~mm}$ size fraction compacted to $90 \%$, and $<19 \mathrm{~mm}$ size fraction compacted $83 \%$ maximum density, assuming

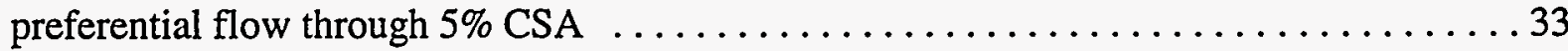

\section{TABLES}

1. Estimated Cost for Alternative Cover Designs for Roswell Municipal Landfill (Ankeny et al., 1997). ......................................

2. Construction Costs for Alternative Cover Designs (Dwyer, 1997) .............. 7

3. RETC Parameter Results Along with Saturated Hydraulic Conductivity and Bulk Density

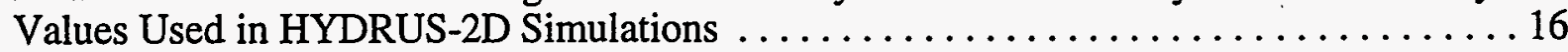

4. HYDRUS-2D Simulation Results from a Single 100-Year Storm Event for a

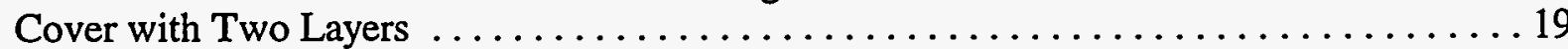

5. HYDRUS-2D Simulation Results from a Single 100-Year Storm Event for a

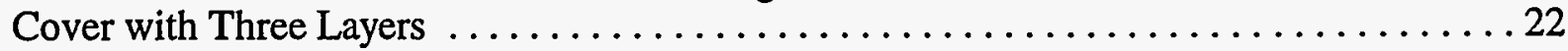

6. HYDRUS-2D Simulation Results from a Single 100-Year Storm Event for a

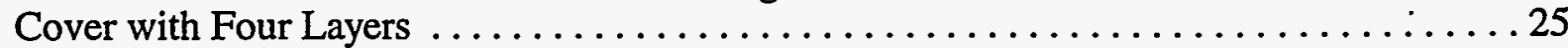




\section{INTRODUCTION}

The DOE/NV Waste Management Program has managed radioactive waste disposal operations since 1961 and provides disposal capability for NTS-generated waste and off-site DOE-approved waste generators. Low-level radioactive, transuranic, mixed, hazardous and classified wastes are disposed in subsidence craters, pits, trenches, landfills and greater confinement boreholes. DOE/NV will eventually close the Area 3 and 5 Radioactive Waste Management Sites (RWMS), Figure 1, for which Bechtel Nevada (Johnejack et al., 1995) developed a proposed closure cap design that included a soil-cement layer as a hydrologic barrier. During performance assessment, concerns developed over the degree and impact of subsidence on the proposed cap and the "hard" soil-cement

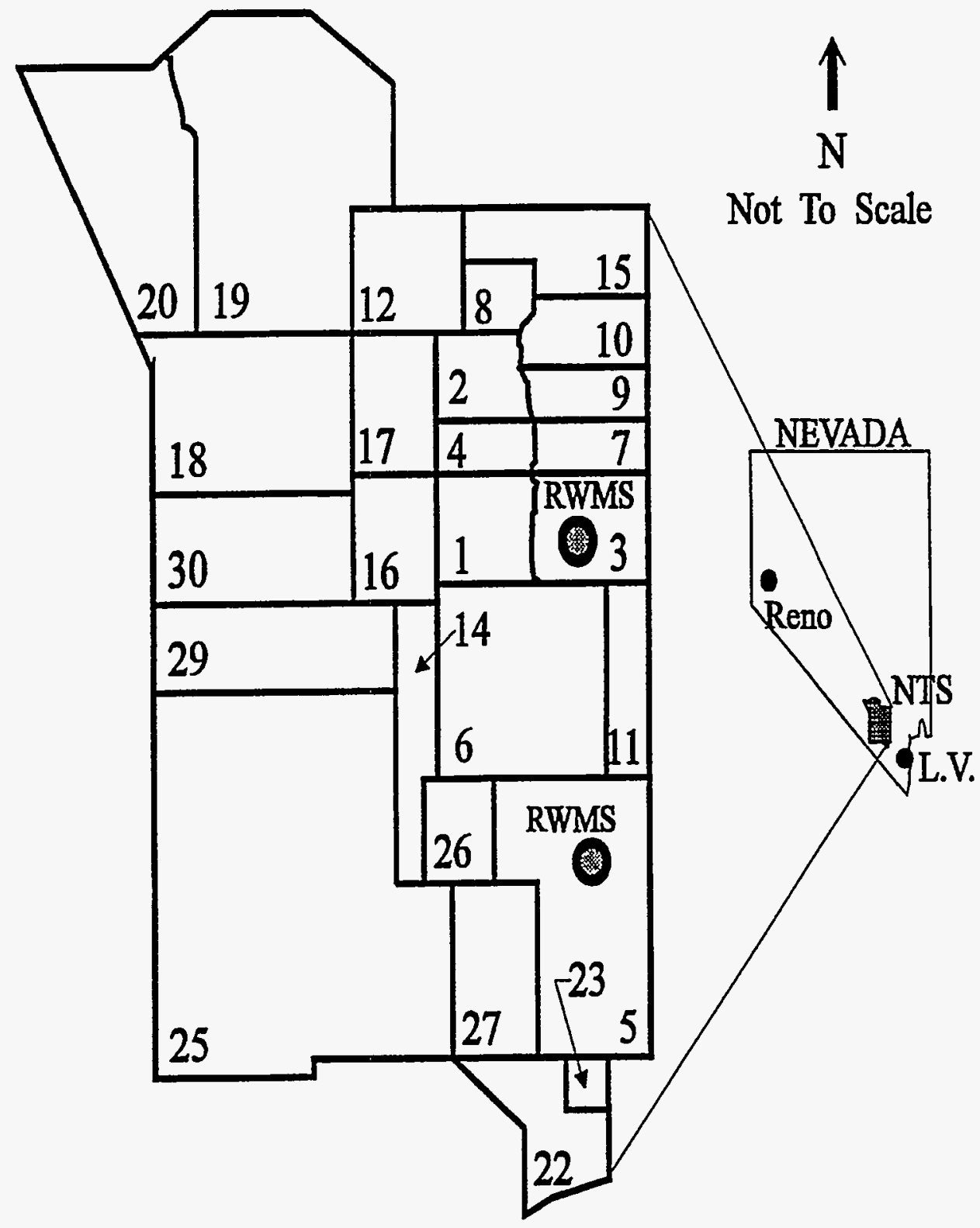

Figure 1. Map of the NTS showing the Area 3 and 5 Radioactive Waste Management Sites (reprinted from Johnejack et al., 1995). 
layer. A working group was convened to evaluate the consequences of subsidence at the Area 3 and Area 5 RWMSs. The consequences of subsidence report (COSR) by Arnold et al. (1997) concluded that waste disposal practices at Areas 3 and 5 have introduced significant void space which will produce subsidence in the long term that will require excessive measures to accommodate. Subsidence is anticipated to be as much as $3.9 \mathrm{~m}(12 \mathrm{ft})$ at Area $3 \mathrm{ax} / \mathrm{bl}, 14.9 \mathrm{~m}(49 \mathrm{ft})$ at Area 3 ah/at, and $5.8 \mathrm{~m}(19 \mathrm{ft}$ ) at Area 5. Concern was expressed that cracks, due to differential subsidence, will provide preferential pathways for infiltration and upward vapor migration, and that depressional areas, due to localized subsidence, will focus runoff into these depressional areas. Both of these subsidence features would likely result in cover failure if not accommodated for in the closure cap design. Gee et al. (1992) noted that recharge through covers in arid conditions is "particularly likely under topographic depressions," such as occurs on covers due to subsidence. The COS working group recommended that a cost-effective "soft" cover that consist of compacted alluvium of sufficient thickness and/or subtle layering could be designed to accommodate subsidence and meet the minimum performance standards established in the COSR. DOE/NV is in the process of designing the "soft" monofil cover, commonly referred to as an ET cover (Figure 2) due to its design and performance being based upon the ability of evapotranspiration to limit infiltration.

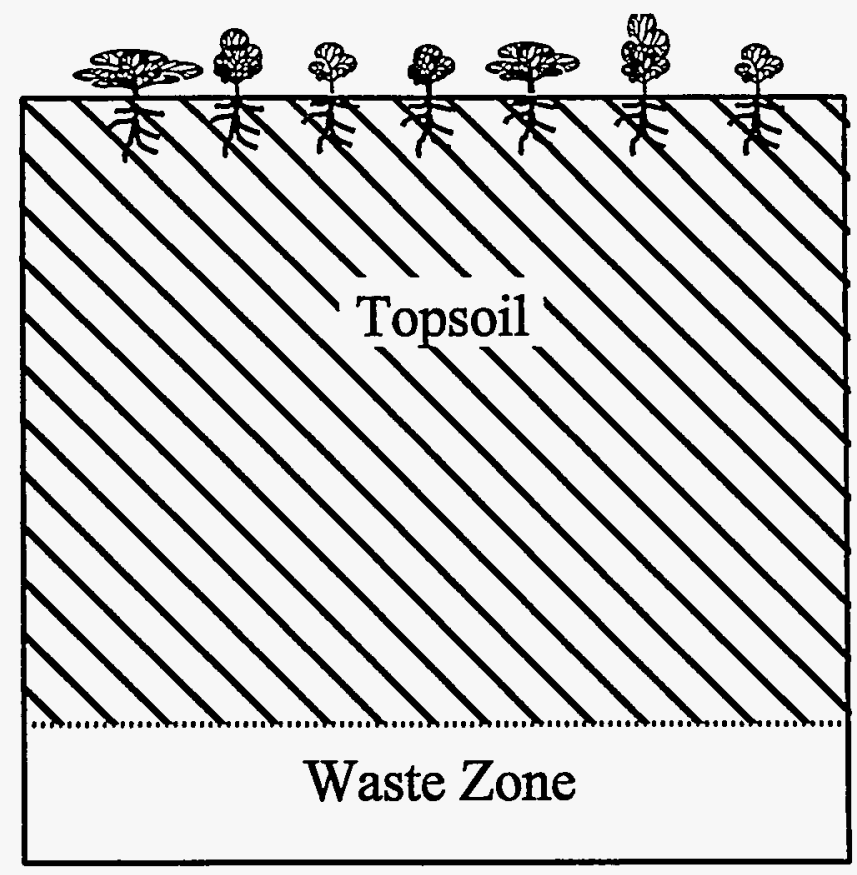

Figure 2. Diagram of a ET monofil cover design.

The RCRA cover design (Figure 3) and regulations for shallow burial of waste are appropriate for areas in which high rates of recharge and shallow depth to groundwater are primary concerns. The climate, soil properties, and great depth to groundwater in much of the arid southwest combine to make these designs inappropriate and/or overly costly. In the lower elevations of the NTS, the precipitation is so low that it is generally considered that all the precipitation eventually returns to the atmosphere via evaporation and transpiration (Shott et al., 1995). Indirect measurements by Tyler et al. (1996) based upon stable isotope analysis of soil water suggest that the recharge in the alluvial 


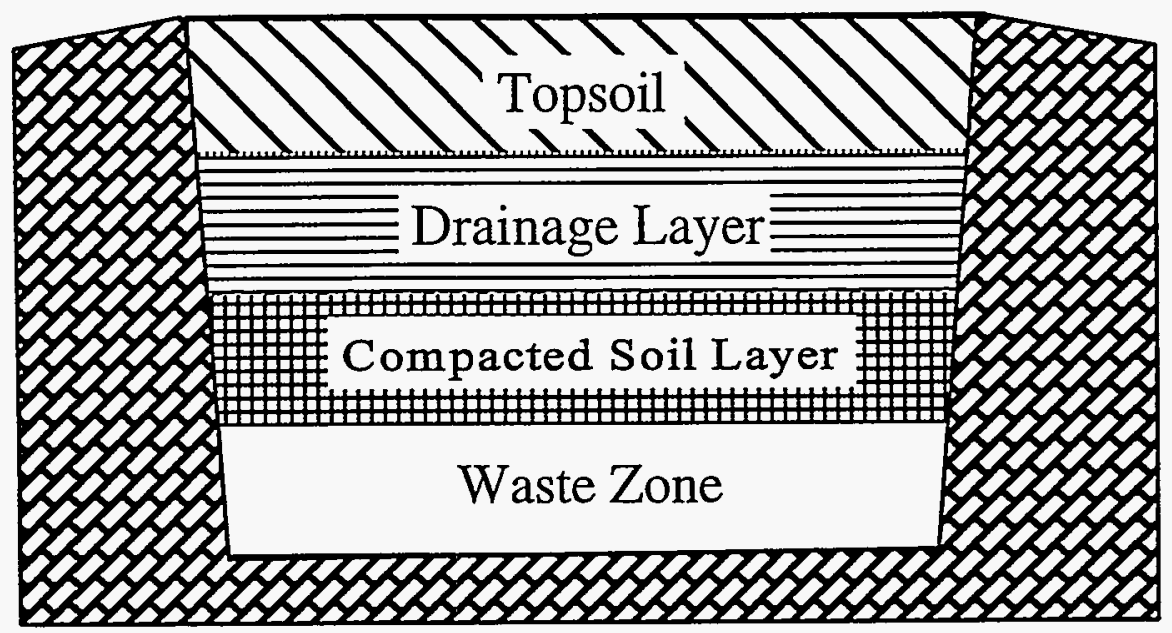

Figure 3. Diagram of a prescriptive RCRA Title C cover design.

fan areas of the NTS has historically been essentially zero under the current climatic conditions. However, Gee et al. (1992) stressed that coarse-textured soil, such as is common in the alluvium of the NTS, and disruptions that limit vegetative growth of deep-rooting plants, such as are common to covers in arid regions for long periods after construction, can induce significant infiltration into the waste even under arid conditions. Even if vegetation is established on the cover to provide water removal by transpiration, the seasonal dynamics of precipitation versus transpiration can result in infiltration into the waste (Gee et al., 1992).

There is additional concern that preferential flow can cause cover failure even for arid conditions (Gee and Ward, 1997; Anderson, 1997). Preferential flow is a generic term applied to situations in which water does not infiltrate uniformly, either in space or velocity, through the soil but instead flows through only a small portion of the soil at higher velocities than would occur if flow were uniform. Preferential flow was originally attributed to flow through large pores, such as biological channels (e.g., worms, roots...) and structural features (e.g., cracks, inter-aggregate voids...). A DOE-funded working group on long-term cover performance (Waugh, 1997) expressed concern over the potential for preferential flowpaths to be established with time as root channels are established. Preferential flowpaths due to root and worm channels typically occupy less than $0.5 \%$ of the cross-sectional area (Wilson and Luxmoore, 1988; Edwards et al., 1987), yet they can dominate the flow (Beven and Germann, 1982) by contributing to as much as $85 \%$ of the flow (Wilson and Luxmoore, 1988). Recently, preferential flow by processes of fingering, funnel flow, and/or unstable flow have been documented (Kung, 1990) for stuctureless coarse-grained media such as common to the NTS alluvium. The latest studies have reported that infiltrating water is funneled into these preferential flow fingers and will continue to percolate through these isolated fingers until they contact a contrasting layer to disrupt the flow finger (Kung, 1990; Wilson et al., 1997; Kinsall et al., 1997). An example of such funnel flow can be seen in the findings of Kinsall et al. (1997) and Wilson et al. (1997), presented in Figure 4. Flow out of two undisturbed soil blocks, during simulated rainfall events that were applied uniformly over the surface, was clearly spatially heterogeneous and these funnel flow areas were stable with time. Wilson et al. (1997) concluded that the more physically homogeneous the porous media, the more heterogeneous these flowpaths. They 

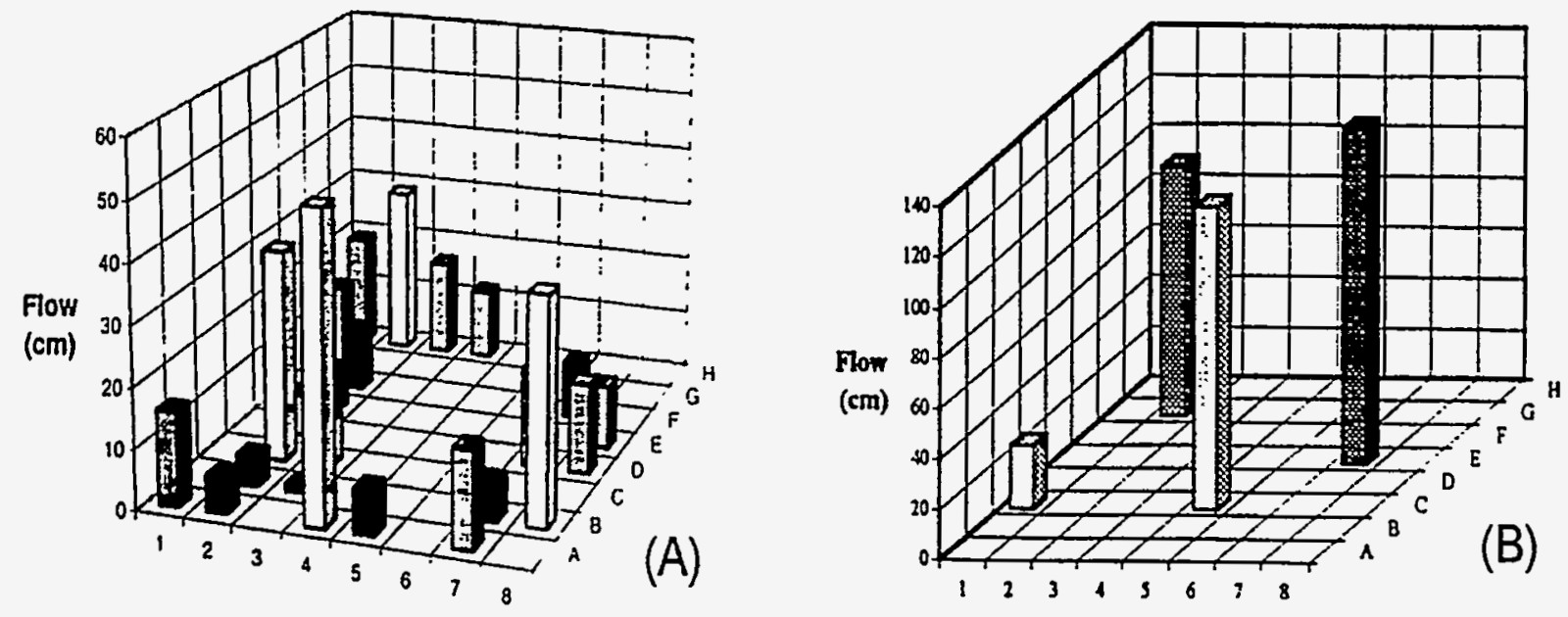

Figure 4. Spatial distribution of cumulative drainage from the bottom of an undisturbed sand block at (a) $4.5 \mathrm{~m}$ depth (Kinsall et al., 1997) and (b) $5.9 \mathrm{~m}$ depth (Wilson et al., 1997).

reported $88 \%$ of the flow through only $4 \%$ of the cross-sectional area for homogeneous, coarsegrained media. This process is likely to occur in monolayer ET covers that do not possess contrasting layers to disrupt the flow fingers. Thus, a thicker cover would be required to prevent infiltration into the waste and increase the long-term risk for failure.

The possibility of this preferential finger-flow occurring suggests that direct measurements of hydrologic performance of monolayer ET covers are needed. Allison et al. (1994) stressed the need for direct physical measurement of the movement through covers due to the observations (Gee et al., 1994) of deep recharge even in desert climates where potential ET (PET) exceeds precipitation by an order of magnitude. Direct measures of flux via lysimetry are the most robust estimator of recharge under arid conditions (Fayer et al., 1996; Tyler and Walker, 1994), however, such facilities are not currently available at the NTS and data acquisition would require long-term monitoring (> 5 years) before confidence could be placed in the results. Sully (unpublished data) instrumented two weighing lysimeters at Area 5 filled with native NTS soil in layers that simulate the natural soil but not the monofil ET cover. These lysimeters will provide direct measurements of the potential recharge of the native soil under current rainfall and PET conditions with bare and vegetative surfaces. These data to date indicate that net recharge is indeed zero, however, this is based on two years of data under current natural rainfall conditions and for the native-layered conditions. While this work will provide excellent baseline data, data on performance of monofil ET covers are seriously lacking (Skahn, 1997) and comparison to the native conditions as a natural analog for cover performance is completely lacking.

DOE/NV can express great confidence in asserting that infiltration into the alluvium is limited to the upper couple of meters (Arnold et al., 1997, Shott et al., 1995), however, it must be kept in mind that this natural analog is highly layered. The assertion of the NTS alluvium being highly layered is in opposition to the report by Schmeltzer et al. (1994) that claims that the Area 3 alluvium is homogeneous. Schmeltzer et al. (1994) referenced the work by Fernald (1974), who compiled data for 42 boreholes, however, the depth increments of these data were approximately $15 \mathrm{~m}$, which 
would preclude any characterization of layering. They also referenced the site characterization data of Holmes and Narver (1962), but this analysis was on drill cuttings which will homogenize the material and not on undisturbed cores samples. Shott et al. (1995) and Johnejack et al. (1994), in reviewing site characterization data for Area 5 by Istok et al. (1994) and Ginanni et al. (1993), respectively, both conceded that there is obvious layering as a result of depositional variations, but concluded that since the physical properties of the material vary little with depth, it "behaves as a homogeneous mass." Yet, the hydraulic conductivity shown in the report by Shott et al. (1995) varied by 2 to 3 orders of magnitude between depth increments. Additionally, Istok et al. (1994) concluded in their refereed paper that the material is homogeneous for bulk density in the horizontal direction but "the alluvium must be considered heterogeneous (layered heterogeneity)" due to significant differences in $\mathrm{K}_{\mathrm{s}}$ and particle size distribution between the vertical layers. It is clear that the natural analog that is effective in limiting recharge is a layered system.

One alternative to monofil ET covers that has gained popularity in semi-arid conditions is the Capillary Barrier design (Figure 5). The principle behind this design is that a positive water pressure

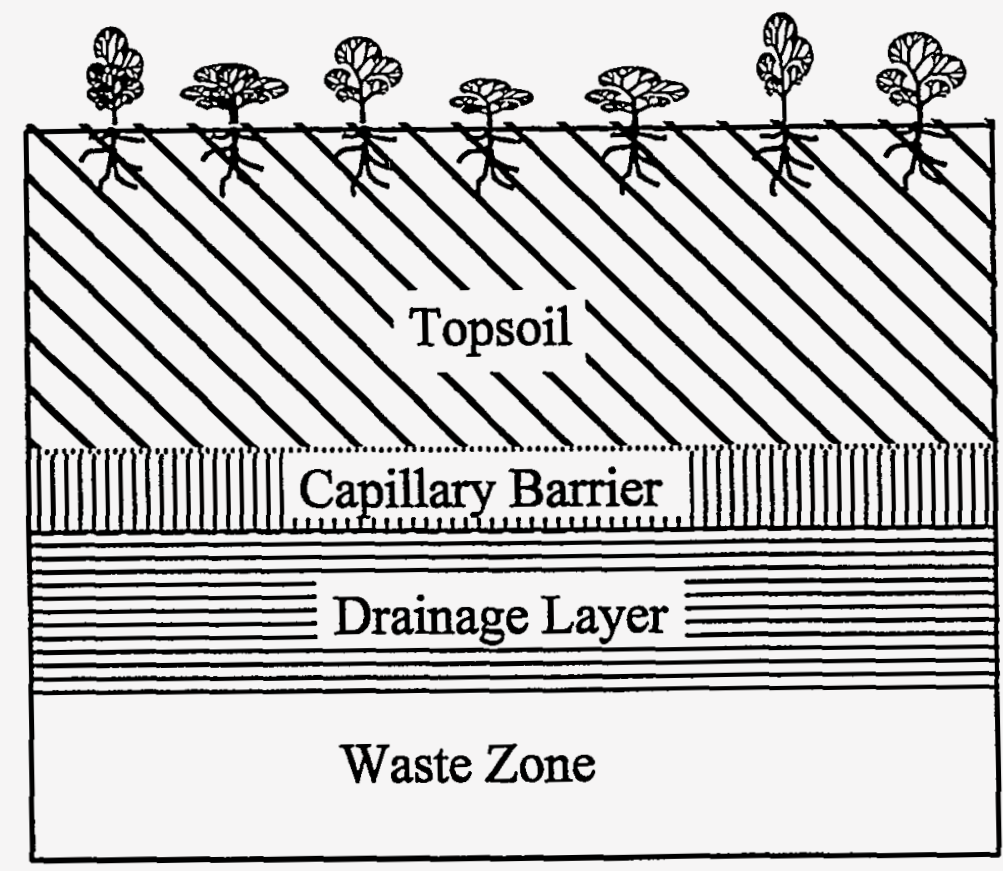

Figure 5. Diagram of a Capillary Barrier cover design.

would be required in the capillary barrier layer for outflow into the coarser-grained (gravel) drainage layer below. Since the cover would be predominately unsaturated in semi-arid regions, this capillary barrier layer would serve to hold water in the upper layers for plants to extract. By sloping the capillary barrier layer, excess water could be laterally diverted to minimize downward movement. This unsaturated flow principle is predicated upon there being a dramatic contrast in particle sizes between the capillary barrier layer and the drainage layer. Two major concerns reported by Waugh (1997) with this design are (1) the mixing of these layers with time due to illuviation and biological activity causing the capillary barrier to lose its effectiveness over the long term, and (2) differential subsidence providing preferential flowpaths directly into the waste zone (Figure 6) as a result of the 
lateral flow divergence in the capillary barrier layer. The COSR suggested that a subtle-layered design (Figure 7) may be cost effective. This design would be based upon the principles of a monofil ET cover but with the added insurance against preferential flow causing infiltration into the waste zone by incorporating layers with subtle variations in particle size distribution and/or compaction analogous to the native alluvium. The cost benefit would be realized through the reduction in depth of cover necessary to prevent infiltration into the waste. Due to the variations in lifts (layers) being subtle, illuviation would not be a concern.

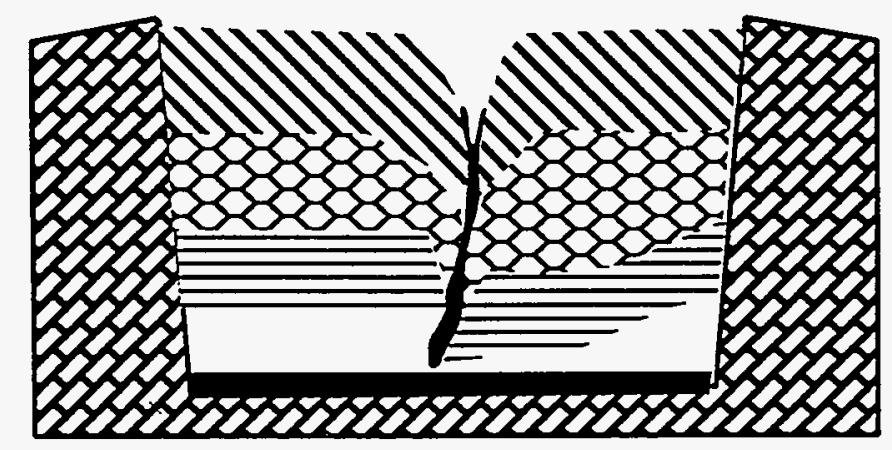

Figure 6. Illustration of hydrologic impacts of subsidence on covers with barrier layers.

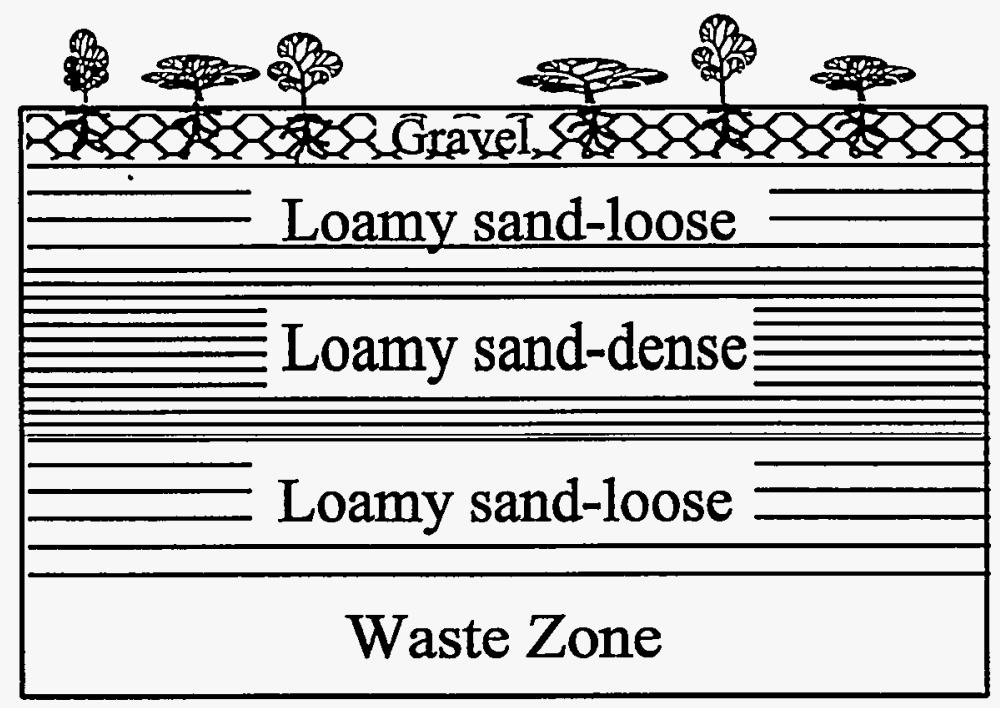

Figure 7. Diagram of a subtle-layered ET cover design.

In addition to performance concerns, a capillary barrier design may be more expensive to construct than an ET cover depending upon the thickness. The cost savings and proficiency in limiting infiltration of an ET cover depends upon the cap depth. Ankeny et al. (1997) estimated the cost of various covers for the Roswell municipal landfill in New Mexico (Table 1). Due to less thickness required, the Capillary Barrier cover was slightly less expensive than the monofil ET cover despite the former including a geotextile to prevent mixing of layers. An ET cover that consists of subtle layering such that a geotextile is not required, but with the benefit of less thickness necessary, would further enhance the cost savings. The costs at a DOE facility are substantially higher than for a municipal facility, thus, the cost savings would be more. This is evident by the study by Dwyer 
(1997), shown in Table 2, for the actual construction cost of covers at Sandia National Laboratories' test facilities. The Soil Cover design, which was by far the most cost-effective, is analogous to the subtle-layering design we propose to test in that it consists of layers of compacted native soil which reduce the cover thickness required.

In addition to cost savings, monofil and subtle-layered ET covers are expected to better accommodate subsidence since infiltration barriers of the more elaborate designs (e.g., capillary barrier, clay barrier, geosynthetic clay liner (GCL)) are likely to fail under such conditions. However, ET covers would continue to function adequately since the infiltration protection is not based upon a hydrologic barrier layer but upon water retention and thickness which would not be affected. ET covers should self-heal, in that deformation of the monofil layer would, at worst, result in some degree of layering, and deformation of the subtle layers may cause an offset of the layers, but their ability to store water and disrupt unstable flowpaths would not be affected. This self-healing would further save in future maintenance costs. The exception to this hypothesis that ET covers can accommodate subsidence is the problem of preferential flow through fractures that are caused by differential subsidence. This problem could be reduced and possibly eliminated if overland flow into

Table 1. Estimated Cost for Alternative Cover Designs for Roswell Municipal Landfill (Ankeny et al., 1997).

\begin{tabular}{lccc}
\hline Cover Design & $\begin{array}{c}\text { Required } \\
\text { Thickness }(\mathrm{cm})\end{array}$ & Cost/ha (\$) & Total Cost (\$) \\
\hline $\begin{array}{l}\text { Prescriptive Cover } \\
\text { (infiltration barrier) }\end{array}$ & 90 & 185,000 & $2,400,000$ \\
Capillary Barrier & 90 & 83,000 & $1,100,000$ \\
ET (high permeability) & 135 & 87,000 & $1,100,000$ \\
GCL Barrier & 103 & 110,000 & $1,400,000$ \\
\hline
\end{tabular}

Table 2. Construction Costs for Alternative Cover Designs (Dwyer, 1997).

\begin{tabular}{lcc}
\hline \multicolumn{1}{c}{ Cover Design } & $\begin{array}{c}\text { Required } \\
\text { Thickness }(\mathrm{cm})\end{array}$ & Cost/ha (\$) \\
\hline $\begin{array}{lcc}\text { Subtitle C-Baseline 2 } \\
\text { (Compacted clay barrier) }\end{array}$ & 90 & 929,000 \\
GCL Cover-Alternative 1 & 90 & $1,576,000$ \\
Capillary Barrier-Alt. 2 & 140 & 965,000 \\
ET Cover-Alt. 4 & 90 & 727,000 \\
Soil Cover-Baseline 1 & 60 & 524,000 \\
\hline
\end{tabular}


these surface cracks is eliminated. Thus, the cover should not only prevent run-on, but should be designed with a surface layer with a high infiltration capacity, e.g. surface armoring layer, such that localized run-off is minimal. Under such conditions, preferential flow through the fractures would be restricted by the drainage rate out of the surface armoring layer.

\section{OBJECTIVES}

DOE/NV has elected to redesign the cover for Area 3 to a monofil ET cover design. This report will not review the hydrogeologic conditions or the waste disposal regulations that have led to this decision, as this information can be found in the literature referenced in this report. The objective of this project was to (1) determine the physical and hydraulic properties of the Area 3 borrow source and (2) use these properties in a physically rigorous unsaturated flow code to numerically evaluate various design options. Specifically, the impact of preferential flow on cover thickness will be evaluated, and the concept of a subtle-layered ET cover to disrupt these flowpaths will be demonstrated.

\section{NUMERICAL METHODS}

Traditionally, water flow was considered to be uniform through relatively homogeneous layers of the soil profile. Darcy's Law describes steady-state unsaturated flow as:

$$
\mathrm{q}=\mathrm{Q} / \mathrm{At}=-\mathrm{K}(\mathrm{h}) \mathrm{dH} / \mathrm{dz}
$$

where $q$ is the flux density, i.e., volume of flow $(\mathrm{Q})$ per area $(A)$ per time $(T)$, with units of length per time. The hydraulic head, $\mathrm{H}$, is the sum of the gravity, $\mathrm{Z}$, and pressure heads, $\mathrm{h}$, with the latter being positive for saturated conditions and negative for unsaturated conditions. The hydraulic conductivity, $\mathrm{K}$, is considered a constant under saturated conditions $(\mathrm{h} \geq 0)$ representing the ability of the soil to conduct water. While $\mathrm{K}$ has units of length per time, it is not the rate or velocity that water moves through soil. The rate that water is being conducted is the product of the hydraulic conductivity and the hydraulic gradient, $\mathrm{dH} / \mathrm{dz}$. The hydraulic gradient is the change in total hydraulic head, $\mathrm{H}$, with distance, $\mathrm{z}$, and is the driving force causing flow. While the flux density, $\mathrm{q}$, has units of velocity, it is only a macroscopically average velocity that water is moving through soils, not the velocity that water is moving through pores. The average pore water velocity, $\mathrm{v}$, is taken as the flux density, q, divided by the ratio of the pore area actually contributing to flow to the total area, i.e., the effective porosity.

Unfortunately, flow through the vadose zone, unsaturated zone from the soil surface to the groundwater table, is rarely if ever steady or one-dimensional under natural conditions. Thus, Darcy's Law must be extended to transient three-dimensional flow conditions by the continuity equation

$$
\partial \theta / \partial \mathrm{t}=-\left[\partial \mathrm{q}_{\mathrm{x}} / \partial \mathrm{x}+\partial \mathrm{q}_{\mathrm{y}} / \partial \mathrm{y}+\partial \mathrm{q}_{z} / \partial \mathrm{z}\right]=-\nabla \cdot \mathrm{q}
$$

Since $\partial \theta / \partial t=(\partial \theta / \partial \mathrm{h})(\partial \mathrm{h} / \partial \mathrm{t})=\mathrm{C}(\theta) \partial \mathrm{h} / \partial \mathrm{t}$, the three-dimensional transient flow equation, known as Richard's equation for isotropic soil, $\mathrm{K}_{\mathrm{x}}=\mathrm{K}_{\mathrm{y}}=\mathrm{K}_{\mathrm{z}}=\mathrm{K}(\mathrm{h})$, is 


$$
\mathrm{C}(\theta) \partial \mathrm{h} / \partial \mathrm{t}=\mathrm{K}(\mathrm{h})\left[\partial^{2} \mathrm{~h} / \partial \mathrm{x}^{2}+\partial^{2} \mathrm{~h} / \partial \mathrm{y}^{2}+\partial^{2} \mathrm{~h} / \partial \mathrm{z}^{2}+\partial \mathrm{h} / \partial \mathrm{z}\right]
$$

The specific water capacity, $C(\theta)$, is the slope of the water retention curve, $\theta(\mathrm{h})$. The water retention curve is a fundamental soil property that represents the relationship between the water content, $\theta$, and the soil-water energy status, $h$, called the pressure head. The water retention function, $\theta(h)$, reflects the physical properties of the soil such as texture and structure, and its shape is dependent upon the pore-size distribution.

Water retention curves are typically determined experimentally because no theory has been developed yet that is accurate enough to derive it analytically based upon the soil's physical characteristics, although many methods are currently being proposed. Fractal theory and capillary bundle theory have tried with limited success. Thus, to obtain the $\theta(\mathrm{h})$ function, one must fit the experimental data with empirical expressions. Van Genuchten (1980) developed the following water retention model:

$$
\theta=\theta_{\mathrm{r}}+\left[\theta_{\mathrm{s}}-\theta_{\mathrm{r}}\right] /\left[1+(\alpha \mathrm{h})^{\mathrm{n}}\right]^{\mathrm{m}},
$$

where $h$ is the absolute value of the matric head. The $\theta_{\mathrm{r}}$ is the residual water content, and $\alpha\left(\mathrm{cm}^{-1}\right)$ and $\mathrm{n}$ are fitted parameters assuming $\mathrm{m}=1-1 / \mathrm{n}$. It has been proposed that the fitted parameters have physical significance in which $\alpha$ is a measure of the air-entry value (pressure head at which air enters the soil) and the product $\mathrm{mn}$ is a measure of the pore-size distribution.

Hydraulic conductivity is a macroscopic value that represents an overall average of the microscopic velocities of the different pores and within pores over the total soil volume. For saturated soil, $\mathrm{K}_{\mathrm{s}}$ is a constant (with high spatial and experimental variability) that represents the cumulative effects of soil structure (pores: size distribution, connectivity, and tortuosity), soil particles (size distribution and mineralogy), and soil water properties (solute concentration, $\mathrm{T}$, viscosity). For unsaturated soil, the soil water is under negative pressure head, i.e., matric head. Water flow is still in the direction of decreasing energy, from higher soil water pressure to lower soil water pressure, however, the proportionality factor equating the flux to the hydraulic gradient is not a constant value but is dependent upon the water content and matric head. Thus, for unsaturated soil, $\mathrm{K}(\mathrm{h}, \theta)$ is not a unique value but dependent upon the hydrologic conditions (matric head and water content) with extreme spatial, temporal, and experimental variability.

One of the greatest difficulties in predicting unsaturated water flow is in determining the $\mathrm{K}(\mathrm{h})$ properties. Empirical models are simple mathematical equations adjusted by least-squares fitting to match experimental data but have no physical process basis for the mathematical expression. Physical models for $\mathrm{K}(\mathrm{h})$ require knowledge of a soil property that is correlated by some physical law or numerical expression to the ability of the soil to conduct water, such as particle-size or poresize distributions. Since the shape of the water retention curve is a reflection of the pore-size distribution, which is directly related to flow velocity, there is a relationship between the $\theta(\mathrm{h})$ function and $\mathrm{K}(\mathrm{h})$ function. One such relationship is the van Genuchten model (1980), where:

$$
\mathrm{K}_{\mathrm{t}}=\mathrm{K}(\mathrm{h}) / \mathrm{K}_{\mathrm{s}}=\frac{\left\{1-(\alpha \mathrm{h})^{\mathrm{n}-1}\left[1+(\alpha \mathrm{h})^{\mathrm{n}}\right]^{-\mathrm{m}}\right\}^{2}}{\left[1+(\alpha \mathrm{h})^{\mathrm{n}}\right]^{\mathrm{m} / 2}} \text {. }
$$


Here, $\alpha, \mathrm{n}$, and $\mathrm{m}$ are determined from $\theta(\mathrm{h})$ parameterization. Parameter optimization is obtained using the Marquardt nonlinear least-squares fitting procedure.

\section{HYDRUS-2D}

The HYDRUS-2D code developed by Simunek et al. (1996) uses the van Genuchten expressions (Equations 4 and 5) to solve the two-dimensional Richard's equation (Equation 3) to model unsaturated flow. The flow domain for evaluating various cap design options was $50 \mathrm{~cm}$ wide by $300 \mathrm{~cm}$ deep. Simulations were made for six hours of rainfall at a rate of $0.66 \mathrm{~cm} / \mathrm{hr}$, which was equivalent to the NTS 100 yr-6 hour storm event (Miller et al., 1973), followed by a sufficient period of evapotranspiration for internal drainage to essentially cease. The evaporation rate of $0.005 \mathrm{~cm} / \mathrm{hr}$ was equivalent to the average ET rate at the NTS during December to January (Shott et al., 1995), assuming that actual ET was $80 \%$ of the potential ET.

\section{MATERIALS AND METHODS}

The physical and hydraulic properties of the native soil from the Area 3 borrow source were tested. The material underwent a particle-size analysis, modified proctor compaction test, a constanthead hydraulic conductivity for two different bulk densities, and water retention for two different bulk densities. This information was then incorporated into the computer model HYDRUS-2D for simulation of infiltration into prescribed cover designs under extreme (100 yr-6 hr) precipitation events.

\section{Particle-Size Analysis}

The particle-size distribution was determined by the sieve and hydrometer mechanical analysis methods (ASTM, 1990). All material that had a diameter greater than $19 \mathrm{~mm}$ ( $3 / 4 \mathrm{in})$ was removed, and subsequently passed through $50 \mathrm{~mm}$ ( $2 \mathrm{in}), 37.5 \mathrm{~mm}$ (1.5 in), $25 \mathrm{~mm}(1 \mathrm{in})$, and $19 \mathrm{~mm}$ ( $3 / 4 \mathrm{in})$ diameter sieves. The amount of sample retained on each sieve was weighed. A subsample that would be easier to work with was separated out of the original by repeatedly splitting the sample. This smaller sample was weighed and then washed through the No. $200(0.080 \mathrm{~mm})$ sieve to remove the silt and clay sized particles. The remaining sample was then oven dried and sorted through the 12.7 $\mathrm{mm}$ (1/2 in), $9.5 \mathrm{~mm}$ (3/8 in), $4.75 \mathrm{~mm}$ (No. 4), $2 \mathrm{~mm}$ (No. 10), $1.180 \mathrm{~mm}$ (No. 16), $0.85 \mathrm{~mm}$ (No. 20), $0.25 \mathrm{~mm}$ (No. 60), $0.15 \mathrm{~mm}$ (No. 100), and $0.080 \mathrm{~mm}$ (No. 200) sieves. As before, the weight retained on each sieve was recorded. These data were converted into the percentage of sample by mass of each size fraction.

To determine the grain sizes smaller than the $0.080 \mathrm{~mm}$ sieve, the hydrometer method was used (ASTM, 1990). Approximately $40 \mathrm{~g}$ was prepared with $100 \mathrm{ml}$ of sodium hexametaphosphate dispersing solution, and soaked for at least three hours. The presoaked sample was put into a blender and mixed thoroughly for five minutes before decanting into a sedimentation cylinder. The dispersed sampled was brought up to volume in a $1000 \mathrm{ml}$ sedimentation cylinder. A control blank was set with just distilled water and $100 \mathrm{ml}$ of dispersing solution in another cylinder. The hydrometer was slowly placed into the cylinder and a reading taken at $0.5,1,3,10,30,60,90,120$, and 1440 minutes. After the 24-hour period, the solution in the sedimentation cylinder was washed through 
the No. 230 sieve. The sieved portion was oven-dried and then sorted through a stack of $2.36 \mathrm{~mm}$ (\#8), $1.18 \mathrm{~mm}$ (\#16), $0.85 \mathrm{~mm}$ (\#20), $0.50 \mathrm{~mm}$ (\#35), $0.25 \mathrm{~mm}$ (\#60), $0.125 \mathrm{~mm}$ (\#120), and 0.063 $\mathrm{mm}$ (\#230) sieves by a mechanical shaker for five minutes. The mass retained on each sieve was recorded. This procedure produced a little overlap between the wet-sieving and the post hydrometer dry-sieving due to chemical dispersion of the latter.

\section{Modified Proctor Compaction Test}

The Area 3 material was separated into selected size fractions for testing. The size separations selected for testing were $<19 \mathrm{~mm}(<3 / 4 \mathrm{inch}),<5 \mathrm{~mm}$ ( $<$ No.4 sieve), $<2 \mathrm{~mm}$ ( $<$ No. 10 sieve), and $5 \mathrm{~mm}$ to $2 \mathrm{~mm}$ (No. 4 to No. 10 sieve). The original sample was separated into the desired size fractions by dry-sieving using a $60 \mathrm{~cm}$ by $60 \mathrm{~cm}$ sieve. It was concluded upon inspection of the material that only the $<19 \mathrm{~mm},<5 \mathrm{~mm}$, and $<2 \mathrm{~mm}$ samples would be acceptable for the modified compaction test. The samples separated between these classes ( 19 to $5 \mathrm{~mm}$, and 5 to $2 \mathrm{~mm}$ ) were too coarse and therefore would not successfully compact. Water was added to these samples to obtain moisture contents of $2 \%, 4 \%, 6 \%$, and $8 \%$ by weight. Thus, for each size fraction there were four compaction tests, i.e., one for each respective soil moisture content. Next, $2500 \mathrm{~g}$ of soil were weighed out for each test and water was added to the sample to obtain the prescribed water content. The 12 different test samples sat in their containers overnight to let the soil-water equilibrate. For these tests, a $10 \mathrm{~cm}$ mold was used, with five layers (or lifts) at 25 blows each of a $10 \mathrm{lb}$ hammer dropped from a height of $45 \mathrm{~cm}$ (ASTM, 1992). The material and mold were weighed to determine the mass of the wet soil. The soil was then forced out of the mold and a sub-sample of the soil was weighed (at least $700 \mathrm{~g}$ ). The subsample was reweighed after drying in an oven overnight at $105^{\circ} \mathrm{C}$ to determine the moisture content and the dry bulk density. The dry bulk density was plotted against gravimetric moisture content such that the peak of the graph represents the maximum dry density and optimum moisture content.

These results provided guidance to the rest of the experiments. For the hydraulic conductivity and water retention test, each sample (except the 5 to $2 \mathrm{~mm}$ ) was compacted at $90 \%$ maximum density and $83 \%$ maximum density. The 5 to $2 \mathrm{~mm}$ sample was too coarse to determine a maximum dry density, so the sample was compacted as well as could be and the density recorded.

\section{Water Retention}

The hanging water column and pressure plate extraction methods were employed to determine water retention (Klute, 1986). The cores for this experiment were $6.05 \mathrm{~cm}$ in diameter, and $5.10 \mathrm{~cm}$ in length, which gave a cross-sectional area of $28.75 \mathrm{~cm}^{2}$ and a volume of $146.61 \mathrm{~cm}^{3}$. Each sample size fraction and density was analyzed on replicate cores. The only exception was the $<19 \mathrm{~mm}$ sample, which was not analyzed due to concerns for the coarse gravel (19 to $5 \mathrm{~mm}$ ) complicating the compaction in the small water retention cores. Thus, the $<5 \mathrm{~mm}$ material had a sufficient mass of fine gravel ( 2 to $5 \mathrm{~mm}$ sample) added to it to mimic the $<19 \mathrm{~mm}$ sample. The samples were saturated with distilled water treated with a $0.1 \%$ Phenol solution to prevent biological activity. Porous plate (bubbling pressure $>500 \mathrm{~cm}$ ) buchner funnels $(350 \mathrm{ml}$ ) were saturated in the same solution. The cores were placed into the funnels and allowed to equilibrate with the negative water pressure exerted on the core bottom for a minimum of 24 hours. The distances between the core 
bottom and the outflow air port of the hanging water column equaled the negative water pressure. The samples were subjected to $-25,-50,-100,-150$, and $-200 \mathrm{~cm}$ water pressures. Three lower water pressures $(-500,-750$, and $-1000 \mathrm{~cm})$ were achieved by placing the cores on 1-bar ceramic porous plates and applying a pneumatic pressure with a pressure chamber and allowing a minimum of 48 hours for equilibration. Following the lowest pressure, samples were resaturated and the saturated hydraulic conductivity was determined by simply attaching a cylinder to the top of the core and maintaining a constant head while recording the outflow. Cores were subsequently oven-dried for 48 hours to double check the predetermined dry weights. The van Genuchten (1980) model (Equation 4) was fit to the experimental water retention data to determine the $\theta(\mathrm{h})$ function. The $\theta_{\mathrm{r}}$ (residual water content) was set to slightly below the water content at $1000 \mathrm{~cm}$ water pressure, while $\alpha$ and $n$ were fitted with $m=1-1 / n$ using the RETC computer code of van Genuchten (1980).

\section{Constant-Head Hydraulic Conductivity}

The saturated hydraulic conductivity was determined on repacked samples by the constant-head method (Klute and Dirksen, 1986). The setup consisted of the core (diameter of $8.27 \mathrm{~cm}$ and length of $7.55 \mathrm{~cm}$ ) with porous fabric on both ends, a bottom influent port through which water entered the core and a top outflow plate. The inflow and outflow pressure heads were maintained constant while the outflow into a graduated cylinder was recorded with time.

The $<19 \mathrm{~mm}$ (same fabricated sample used for the water retention) and 5 to $2 \mathrm{~mm}$ samples had only two repetitions, whereas the $<5 \mathrm{~mm}$ and $<2 \mathrm{~mm}$ samples were run in triplicate for each density. To prepare the sample, the amount of soil for the prescribed density was determined and compacted into the core with a hammer. The $<5 \mathrm{~mm}$ samples had carbon dioxide pumped through them prior to saturation, whereas all other samples were simply saturated from the bottom up by placing them in a water bath. Once saturated, the samples were hooked up to the constant head setup previously described. Measurements were taken by picking a fixed volume of outflow and recording the time.

\section{RESULTS}

\section{Particle-Size Analysis}

The results of the particle-size analysis (Figure 8) showed that $96.2 \%$ of the Area 3 borrow source material was finer than $19 \mathrm{~mm}$ (3/4 in) diameter (Appendix A, Table A-1, A-2.1). According to the USDA classification scheme, this material is a gravelly loamy sand with mass fractions of $7.8 \%$ coarse gravel, $26.6 \%$ fine gravel, $46.5 \%$ sand, $11.5 \%$ silt, and $7.6 \%$ clay. The sand size mass fractions were $2.8 \%$ very coarse, $8.0 \%$ coarse, $11.8 \%$ medium, $15.5 \%$ fine, and $8.4 \%$ very fine sand. The resulting curve from the hydrometer test overlaps the wet-sieving analysis for the $<2 \mathrm{~mm}$ sample. The mass fractions determined by dry-sieving following the hydrometer test on the $<2 \mathrm{~mm}$ portion were higher than the wet-sieving on the original sample. This could be because the dispersing solution was able to break down more aggregates into individual particles than accomplished by the physical dispersion of the original sample. More fine particles would have remained attached to larger particles sieved out by the wet-sieve analysis, thereby resulting in a lower mass fraction for the smaller size classes than for the other method. 


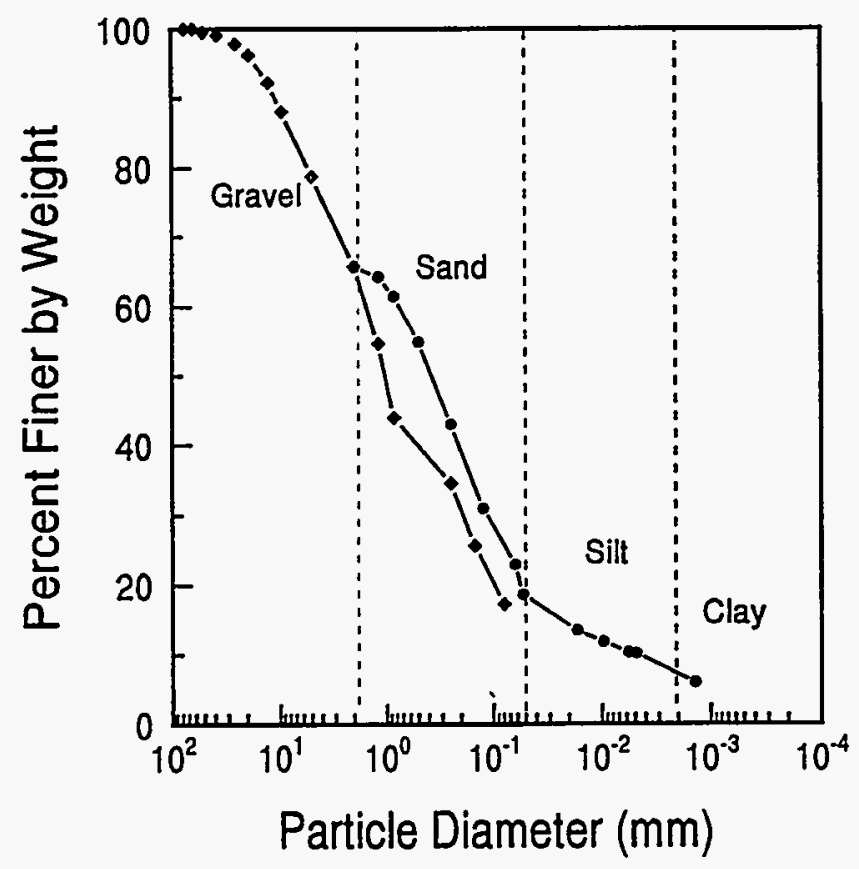

Figure 8. Mass fractions, expressed as percent by weight, of the particle sizes.

\section{Modified Proctor Compaction Test}

The compaction tests resulted in the $<19 \mathrm{~mm}$ sample having a maximum dry density of 1.91 $\mathrm{g} \mathrm{cm}^{-3}$ at an optimum water content of $11.5 \%$ by weight (Appendix B). The $<2 \mathrm{~mm}$ sample had a maximum dry density of $1.84 \mathrm{~g} \mathrm{~cm}^{-3}$ and optimum moisture content of $14.0 \%$ by weight. The $<5 \mathrm{~mm}$ had a maximum dry density of $1.84 \mathrm{~g} \mathrm{~cm}^{-3}$ and optimum moisture content of $12.5 \%$ by weight.

\section{Constant-Head Hydraulic Conductivity}

The saturated hydraulic conductivity, $\mathrm{K}_{\mathrm{s}}$, values were similar within sample treatments with a clear separation between treatments (Figure 9). The $\mathrm{K}_{\mathrm{s}}$ values for the 5 to $2 \mathrm{~mm}$ sample following

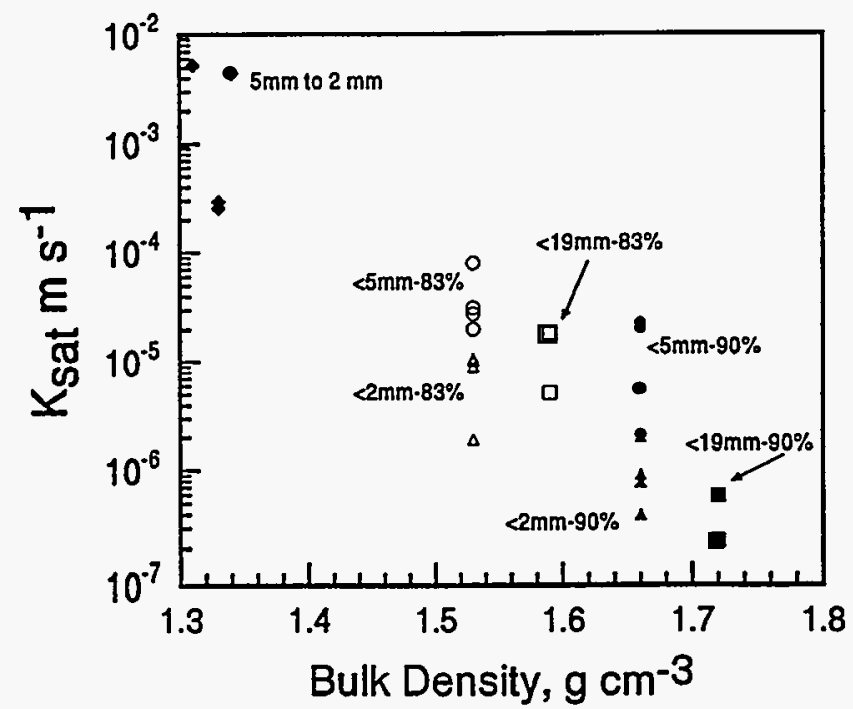

Figure 9. Saturated hydraulic conductivity versus compacted bulk density for the $<19 \mathrm{~mm}$ (squares), $<$ $5 \mathrm{~mm}$ (circles), $<2 \mathrm{~mm}$ (triangles), and 5 to $2 \mathrm{~mm}$ (diamonds) size fractions. 
water retention analysis were an order of magnitude lower than determined on the more accurate constant-head setup, and two orders of magnitude lower for the $<5 \mathrm{~mm}$ fraction at $90 \%$ compaction. The variances are likely due to differences in compaction and saturation methods. As expected, the fine gravel ( 5 to $2 \mathrm{~mm}$ sample) had the highest $\mathrm{K}_{\mathrm{s}}$, on the order of $10^{-3} \mathrm{~m} \mathrm{~s}^{-1}$. The $83 \%$ compaction consistently had a higher $\mathrm{K}_{\mathrm{s}}$ than the $90 \%$ compaction. The geometric mean $\mathrm{K}_{\mathrm{s}}$ for the $<5 \mathrm{~mm}$ sample was $8.5 \times 10^{-6} \mathrm{~m} \mathrm{~s}^{-1}$ at $90 \%$ compaction as compared to $3.4 \times 10^{-5} \mathrm{~m} \mathrm{~s}^{-1}$ at $83 \%$ compaction. The $<2 \mathrm{~mm}$ fraction showed a larger contrast with a geometric mean $\mathrm{K}_{\mathrm{s}}$ of $8.6 \times 10^{-7} \mathrm{~m} \mathrm{~s}^{-1}$ at $90 \%$ as compared to $7.2 \times 10^{-6} \mathrm{~m} \mathrm{~s}^{-1}$ at $83 \%$ compaction. It appears from these data that a slightly larger difference in $\mathrm{K}_{\mathrm{s}}$ is obtained from the subtle difference in particle-size distribution than from differences in compaction. However, since the $<5 \mathrm{~mm}$ at $90 \%$ maximum density and the $<2 \mathrm{~mm}$ at $83 \%$ maximum density had similar $\mathrm{K}_{\mathrm{s}}$ values, ranging between $10^{-6} \mathrm{~m} \mathrm{~s}^{-1}$ to $10^{-5} \mathrm{~m} \mathrm{~s}^{-1}$, similar cap performance may be achievable with either treatment. This makes sense because even though the $<2 \mathrm{~mm}$ is finer than the $<5 \mathrm{~mm}$, it was compacted to a lower density. The $<5 \mathrm{~mm}$ and $<2 \mathrm{~mm}$ samples behaved as expected: $K_{s}$ decreased as density, within each fraction, increased and $K_{s}$ decreased as particle size decreased. The exception appears to be the $<19 \mathrm{~mm}$ sample which had lower $\mathrm{K}_{\mathrm{s}}$ than expected from its particle-size distribution. It is possible for $\mathrm{K}_{\mathrm{s}}$ to decrease as the particle-size range increases, since coarse gravel (19 to $5 \mathrm{~mm}$ ) acts as a nonconductive void effectively reducing the conductive volume of the cores. However, these samples did not contain coarse gravel but were reconstructed with a proportionate amount of fine gravel ( 5 to $2 \mathrm{~mm}$ ) to mimic the $<19 \mathrm{~mm}$ sample. The reduced $\mathrm{K}_{\mathrm{s}}$ values for this size fraction are therefore more likely a result of the higher bulk densities. It should be noted that $K_{s}$ on these samples was only determined after water retention analysis, which also gave low $\mathrm{K}_{\mathrm{s}}$ values for the other size fractions. Therefore, the $K_{s}$ values used in the HYDRUS-2D simulations for the $<19 \mathrm{~mm}$ size fraction were assumed an order of magnitude higher than the values measured.

\section{Water Retention}

There was very little difference in the water retention curves between compaction densities and minimal to substantial differences between size fractions depending upon the size class (Figure 10). Slight differences between different densities were seen at the lower water pressures, $<-100 \mathrm{~cm}$, with the $90 \%$ maximum density retaining more water as expected. It also appears that differences in water retention between the $<5 \mathrm{~mm}$ (Figure 10b) and $<2 \mathrm{~mm}$ (Figure 10c) are negligible. In contrast to these samples, the $<19 \mathrm{~mm}$ sample showed a slightly higher saturated water content and larger decrease at the first negative pressure $(-25 \mathrm{~cm})$ due to a greater abundance of large pores. It should be kept in mind that this $<19 \mathrm{~mm}$ sample does not contain particles $>5 \mathrm{~mm}$ but was fabricated by adding the proportionate amount of fine gravel to simulate $\mathrm{a}<19 \mathrm{~mm}$ sample. Thus, one would expect an even higher saturated water content and bigger decrease in water content at the first negative pressure than was observed for the simulated $<19 \mathrm{~mm}$ sample. This can be seen in the water retention curve for the fine gravel (5 to $2 \mathrm{~mm}$ ) sample which did exhibit a substantial difference in water retention (Figure 10d) when isolated from the finer sand fractions. This size fraction is so coarse that essentially all the water contained under saturated conditions (pressure head $=10^{\circ}$ in Figure 10d) is present in large pores such that it is removed with the slightest negative water pressure. This size fraction may be used, with the $>5 \mathrm{~mm}$ included in it, as the desert armoring 


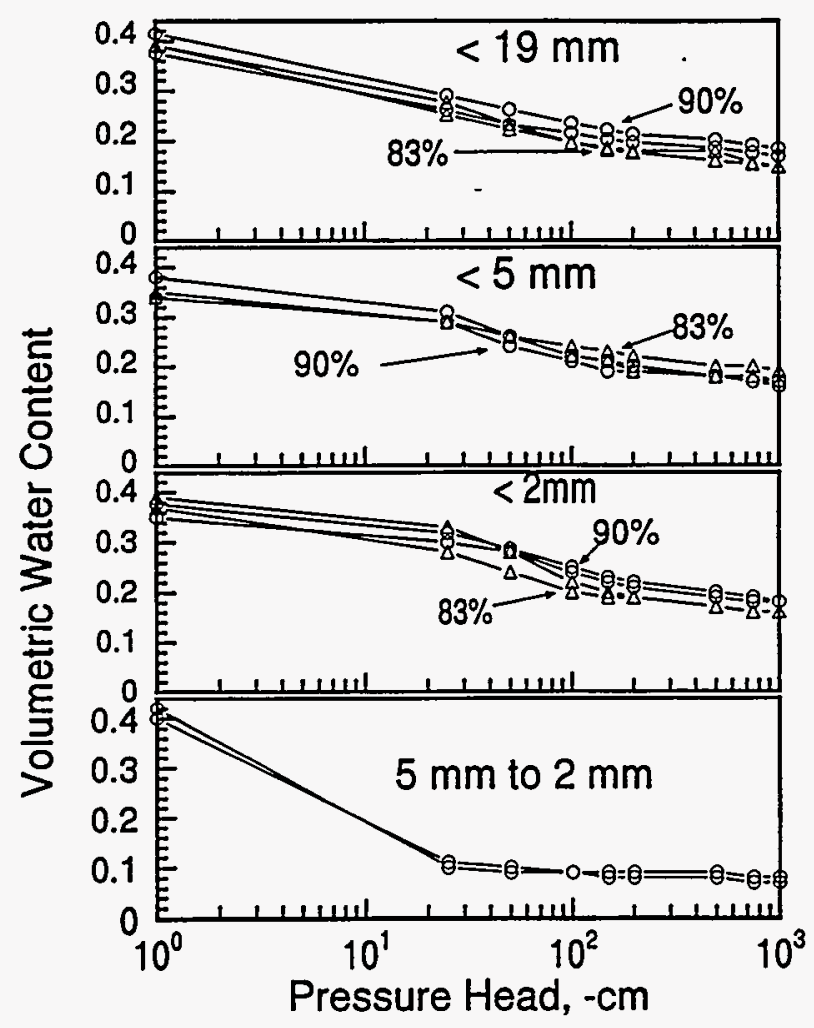

Figure 10. Water retention for samples compacted to $83 \%$ (triangles) and $90 \%$ (circles) maximum dry density for the size fractions: (a) $<19 \mathrm{~mm}$, (b) $<5 \mathrm{~mm}$, (c) $<2 \mathrm{~mm}$ and (d) 5 to $2 \mathrm{~mm}$.

surface layer. This project used the fine gravel $(5$ to $2 \mathrm{~mm})$ size fraction to represent the desert armoring material, but it should be kept in mind that the actual material would be coarser grained. The result would likely be a slightly higher saturated water content, but the bigger difference would be $K_{s}$ value orders of magnitude higher than that obtained for the fine gravel alone.

The RETC computer code by van Genuchten (1980) for modeling water retention (Equation 4) was used to obtain best-fit values for the $\alpha$ and $N$ parameters (Table 3). A value slightly lower than the water content at the $-1000 \mathrm{~cm}$ water pressure was used as the residual water content. Modeling of the water retention data by fitting the residual water content in addition to alpha and $\mathrm{N}$ provided negligible differences in the residual water content value and in goodness of fit $\left(\mathrm{r}^{2}\right)$, so the assumed value was used in the flow simulations. Since the alpha parameter is related to the inverse of the air-entry value, the coarse-grained material should have a higher value, i.e., lower air-entry value. This was seen for the $<19 \mathrm{~mm}$ sample only. Failure to observe this for the 5 to $2 \mathrm{~mm}$ sample is likely due to the inability of the RETC code to obtain a stable convergence to the best fit values. More water content measurements between saturation and $-25 \mathrm{~cm}$ water pressure would be needed for this fraction to obtain a stable fit. Failure to obtain a stable fit to the fine gravel fraction should not affect the accuracies of the flow simulations. Given the extremely large $K_{s}$ values for this fraction, the retention properties, other than total porosity, which is not dependent upon the model fit, would not be important. A lower alpha value for the $90 \%$ than the $83 \%$ maximum density was also expected, but this was not observed due to the lack of difference in water retention characteristics at the wet end between compactions. 
Table 3. RETC Parameter Results Along with Saturated Hydraulic Conductivity and Bulk Density Values Used in HYDRUS-2D Simulations.

\begin{tabular}{lccccccc}
\hline $\mathrm{D}$ & $\theta_{\mathrm{s}}$ & $\theta_{\mathrm{r}}$ & $\begin{array}{c}\mathrm{a} \\
\mathrm{cm}^{-1}\end{array}$ & $\mathrm{~N}$ & $\mathrm{r}^{2}$ & $\begin{array}{c}\mathrm{K}_{\text {sat }} \\
\mathrm{cm} \mathrm{h}^{-1}\end{array}$ & $\begin{array}{c}\text { Bulk } \\
\text { Density } \\
\mathrm{g} \mathrm{cm}^{-3}\end{array}$ \\
\hline 5 to $2 \mathrm{~mm}$ & 0.42 & 0.03 & 0.0806 & 2.1322 & $\mathrm{NA}$ & 1724 & 1.32 \\
5 to $2 \mathrm{~mm}$ & 0.42 & 0.03 & 0.0932 & 2.0677 & $\mathrm{NA}$ & 1724 & 1.32 \\
$<19 \mathrm{~mm} \mathrm{90 \%}$ & 0.40 & 0.15 & 0.3025 & 1.3034 & .998 & 0.21 & 1.72 \\
$<19 \mathrm{~mm} \mathrm{90 \%}$ & 0.42 & 0.15 & 0.2070 & 1.3476 & .998 & 0.21 & 1.72 \\
$<19 \mathrm{~mm} \mathrm{83 \%}$ & 0.42 & 0.14 & 0.1256 & 1.4576 & .997 & 6.48 & 1.59 \\
$<19 \mathrm{~mm} 83 \%$ & 0.42 & 0.14 & 0.3034 & 1.3577 & .995 & 6.48 & 1.59 \\
$<5 \mathrm{~mm} \mathrm{90 \%}$ & 0.34 & 0.15 & 0.0962 & 1.3465 & .998 & 6.23 & 1.66 \\
$<5 \mathrm{~mm} \mathrm{90 \%}$ & 0.34 & 0.15 & 0.0457 & 1.6051 & .993 & 6.23 & 1.66 \\
$<5 \mathrm{~mm} \mathrm{83 \%}$ & 0.34 & 0.15 & 0.9206 & 1.2972 & .921 & 15.2 & 1.53 \\
$<5 \mathrm{~mm} \mathrm{83 \%}$ & 0.34 & 0.15 & 0.0474 & 1.7064 & .992 & 15.2 & 1.53 \\
$<2 \mathrm{~mm} \mathrm{90 \%}$ & 0.35 & 0.15 & 0.0146 & 1.5383 & .996 & 0.23 & 1.66 \\
$<2 \mathrm{~mm} \mathrm{90 \%}$ & 0.35 & 0.15 & 0.0573 & 1.4889 & .997 & 0.23 & 1.66 \\
$<2 \mathrm{~mm} \mathrm{83 \%}$ & 0.39 & 0.15 & 0.0348 & 1.9211 & .999 & 3.55 & 1.53 \\
$<2 \mathrm{~mm} \mathrm{83 \%}$ & 0.39 & 0.15 & 0.0684 & 1.7121 & .998 & 3.55 & 1.53 \\
\hline
\end{tabular}

\section{Cover Design Evaluations Using HYDRUS-2D}

A total of 30 unsaturated flow simulations were made with the HYDRUS-2D code. It should be noted that these simulations were not made to make a definitive assessment of cover performance, but to scope out various design options. It was assumed that the most likely scenario for cover failure from an infiltration standpoint is an extreme precipitation event during a period of low ET (i.e., late fall through winter). Therefore, all simulations were for the same antecedent moisture conditions (water pressure $=-1000 \mathrm{~cm}$ ), with a single $100 \mathrm{yr}-6$ hour storm event. Simulations were continued until water redistribution stabilized, i.e., negligible increase in the depth of infiltration, which was found to be 840 hours. The design combinations included two-layered, three-layered and fourlayered covers. For each case, the upper layer $(0$ to $15 \mathrm{~cm})$ consisted of the fine gravel (5 to $2 \mathrm{~mm}$ size fraction) to simulate desert armoring. Each case was simulated assuming spatially uniform flow, then simulations repeated assuming that infiltration was preferentially funneled through a $5 \%$ crosssectional area (CSA). For the preferential flow simulations, the lateral extent of each layer was 
conceptually divided into 20 vertical sections each consisting of 5\% CSA. One 5\% CSA section was randomly chosen from each layer, except for the surface layer. The water retention curves were the same for all sections within a layer, however, the $\mathrm{K}_{\mathrm{s}}$ for all sections except the one randomly chosen was set to be four orders of magnitude lower than the measured value. Thus, infiltrating water would prefer to move through the 5\% CSA with the measured $\mathrm{K}_{\mathrm{s}}$ value than the remaining $95 \% \mathrm{CSA}$ with a hydraulic conductivity that was substantially lower. The material properties distributions for the three-layered cases and the corresponding preferential flow cases can be seen in Figure 11. All simulations had extremely low mass balance errors with $>90 \%$ having mass balance errors of $<1 \%$ and the highest observed being only $3 \%$.

Due to the extremely high hydraulic conductivity of the surface layer in all simulations, this gravel material allowed all precipitation of a $100 \mathrm{yr}-6$ hour storm event to infiltrate with zero runoff. This is advantageous, not only from the standpoint of preventing erosion, but if differential subsidence features such as fissures exist, water will have to move laterally through this layer to enter these fissures instead of the more rapid process of overland flow. Due to the large size of the pores, as indicated from the water retention curves, and the high flow rates through this layer, surface sealing should not be expected, as aeolian materials will be readily transported through this layer. Sealing at the layer interfaces may be a concern if the contrast in particle-size distributions is dramatic. However, the native alluvium material is sufficiently coarse that the size separations tested ( $<19 \mathrm{~mm},<5 \mathrm{~mm}$, and $<2 \mathrm{~mm}$ ) should not cause a sealing at the interfaces, particularly for the case of a $83 \%$ maximum density being used as the root zone media layer (layer just below the desert armoring).

The two-layer cover design is the monofil ET design which the COSR (Arnold et al., 1997) recommended but with surface armoring. The depth of infiltration and the impact of preferential flow are presented in Table 4 . On average, compaction to the $83 \%$ maximum dry density resulted in infiltration to the $146 \mathrm{~cm}$ depth as compared to the $97 \mathrm{~cm}$ depth for the $90 \%$ maximum dry density compaction if flow is uniform. While there is a large reduction in depth required by compacting to the $90 \%$ level, the depth necessary for meeting the minimum standard for limiting infiltration can be easily achieved without the added construction cost for compaction. The impact of varying the particle size distributions is more difficult to assess due to the complication of higher bulk densities for the $<19 \mathrm{~mm}$ size class. If this size class had the same maximum dry density as the other two classes $(<5 \mathrm{~mm}$ and $<2 \mathrm{~mm}$ ), one should expect a similar response as was observed for them. The average depth of infiltration was $164 \mathrm{~cm}$ for the $<5 \mathrm{~mm}$ as compared to $115 \mathrm{~cm}$ for the $<2 \mathrm{~mm}$, which would suggest an average infiltration depth of over $200 \mathrm{~cm}$ for the $<19 \mathrm{~mm}$ size class if compacted to the same density. It appears for the case of uniform flow through a monofil cover that compaction had an equal impact on reducing the depth of infiltration as the variations in particle size class.

Assuming uniform flow, the maximum depth of infiltration from a single 100-yr maximum storm event averaged $121 \mathrm{~cm}$ for the six cases. However, if preferential flow does occur due to funnel flow processes, the maximum depth predicted averaged $153 \mathrm{~cm}$ for these six cases. Both worse cases occurred for the $<5 \mathrm{~mm}$ material compacted at $83 \%$ maximum density, and comparing 

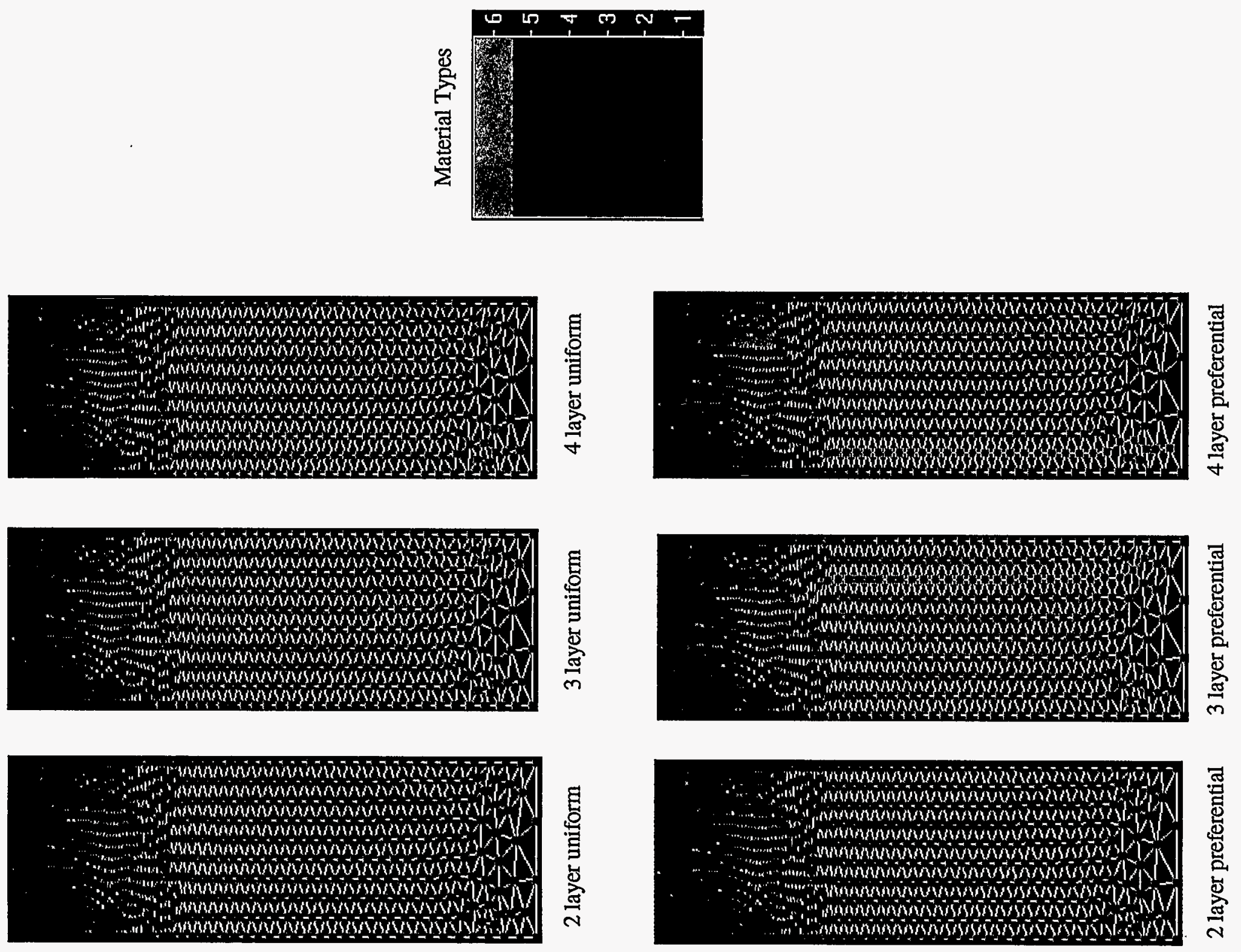

昜

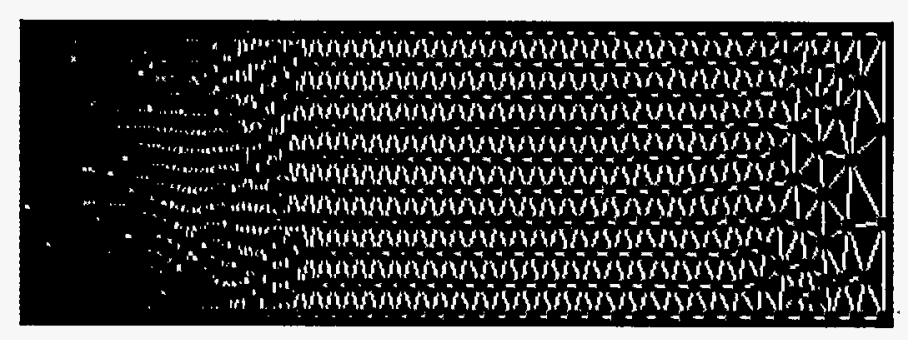

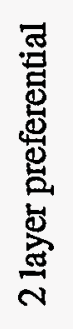


Table 4. HYDRUS-2D Simulation Results from a Single 100-Year Storm Event for a Cover with Two Layers.

\begin{tabular}{|c|c|c|c|c|}
\hline Materials Order & $\begin{array}{c}\text { Layering } \\
\text { Depths }(\mathrm{cm})\end{array}$ & $\begin{array}{l}\text { Max. Infil. Depth } \\
\text { (cm), Uniform } \\
\text { Flow } \\
\end{array}$ & $\begin{array}{l}\text { Max. Infil. Depth } \\
\text { (cm), Preferential } \\
\text { Flow } \\
\end{array}$ & $\begin{array}{c}\text { Impact of } \\
\text { Preferential } \\
\text { Flow \% Change }\end{array}$ \\
\hline $\begin{array}{l}5 \text { to } 2 \mathrm{~mm} \text { over } \\
<19 \mathrm{~mm}-83 \%\end{array}$ & $\begin{array}{l}0 \text { to } 15 \\
15 \text { to } 300\end{array}$ & 139 & 159 & $14 \%$ \\
\hline $\begin{array}{l}5 \text { to } 2 \mathrm{~mm} \text { over } \\
<19 \mathrm{~mm}-90 \%\end{array}$ & $\begin{array}{l}0 \text { to } 15 \\
15 \text { to } 300\end{array}$ & 33 & 33 & $0 \%$ \\
\hline $\begin{array}{l}5 \text { to } 2 \mathrm{~mm} \text { over } \\
<5 \mathrm{~mm}-83 \%\end{array}$ & $\begin{array}{l}0 \text { to } 15 \\
15 \text { to } 300\end{array}$ & 180 & 247 & $37 \%$ \\
\hline $\begin{array}{l}5 \text { to } 2 \mathrm{~mm} \text { over } \\
<5 \mathrm{~mm}-90 \%\end{array}$ & $\begin{array}{l}0 \text { to } 15 \\
15 \text { to } 300\end{array}$ & 147 & 190 & $29 \%$ \\
\hline $\begin{array}{l}5 \text { to } 2 \mathrm{~mm} \text { over } \\
<2 \mathrm{~mm}-83 \%\end{array}$ & $\begin{array}{l}0 \text { to } 15 \\
15 \text { to } 300\end{array}$ & 119 & 170 & $43 \%$ \\
\hline $\begin{array}{l}5 \text { to } 2 \mathrm{~mm} \text { over } \\
<2 \mathrm{~mm}-90 \%\end{array}$ & $\begin{array}{l}0 \text { to } 15 \\
15 \text { to } 300\end{array}$ & 111 & 120 & $8 \%$ \\
\hline
\end{tabular}

results for the uniform (Figure 12) to the preferential flow case (Figure 13) clearly shows the concern. On average, preferential flow resulted in $26 \%$ deeper penetration of the wetting front. Thus, a 3-m-deep monofil as recommended in the COSR would be sufficient to meet the minimum standard of limiting infiltration into the waste zone even with the preferential flow in these simulations. For infiltration to reach the waste zone, either antecedent moisture conditions would need to be wetter than the $-1000 \mathrm{~cm}$ water pressures used in these simulations, or multiple storm events, as opposed to the single event used in these simulations, would need to occur before the soil water storage capacity is fully restored. Another concern is that plant root channels will develop with time over the 1000-year life of a cover. These can provide preferential flow pathways that occupy an order of magnitude lower CSA, thus, substantially deeper penetration than that simulated for funnel flow through $5 \%$ CSA is possible.

The importance of layering by variations in compaction and soil texture can be easily seen in the flow simulations for the three-layer case (Table 5). The most likely scenario is to have the root zone, which was assumed to only be $30 \mathrm{~cm}$ thick, to be compacted to the $83 \%$ maximum density, however, both $83 \%$ and $90 \%$ compaction cases were simulated for comparison. The average depth of infiltration for the six cases decreased from $121 \mathrm{~cm}$ for the two layer to $109 \mathrm{~cm}$ for the three-layer designs. The real benefit of layering, however, is seen in the preferential flow simulations. Instead of increasing the depth of infiltration, as was the case with the two-layer (monofil) design, the depth of infiltration is decreased by $31 \%$ on average. This can been seen in the worst case simulation, which was the $<5 \mathrm{~mm}-90 \%$ over the $83 \%$ maximum dry density. If flow is uniform (Figure 14), the root-zone layer compacted at $90 \%$ maximum density is not able to restrict the wetting front from 
entering the more permeable sublayer. However, since preferential flowpaths at the interface of these two layers do not vertically line up, the preferential flowpath is restricted until the lateral flow over the interface reaches the preferential flowpath for the sublayer (Figure 15). The preferential flowpath through the sublayer will become hydrologically active but the delay provides time for enhanced ET losses and results in shallower depth of penetration even during this low ET period.
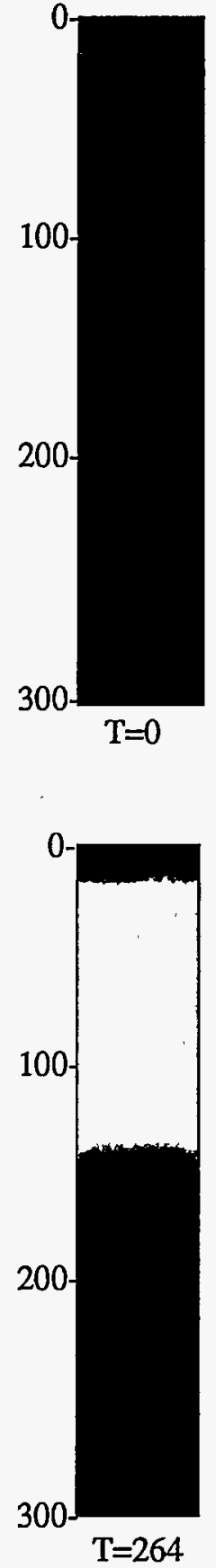

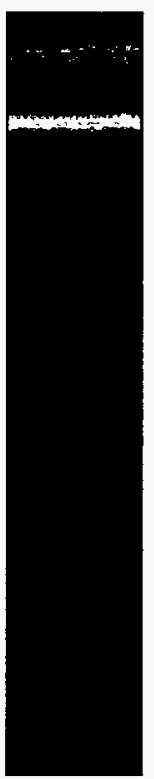

$\mathrm{T}=6$

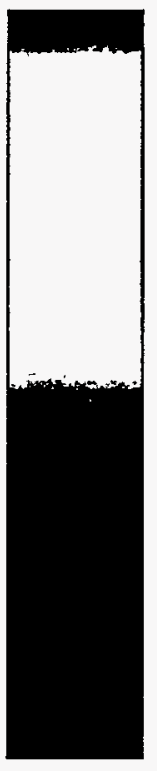

$\mathrm{T}=456$

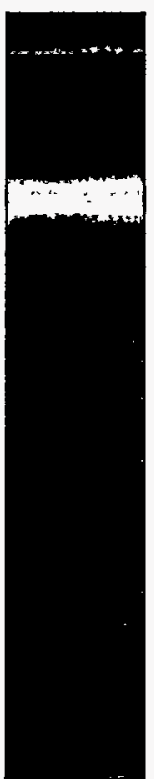

$\mathrm{T}=24$

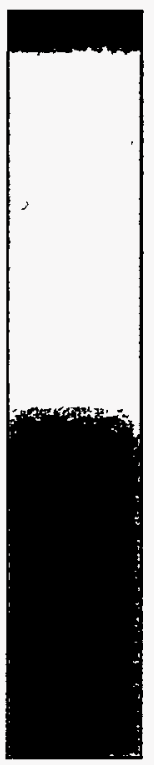

$\mathrm{T}=640$

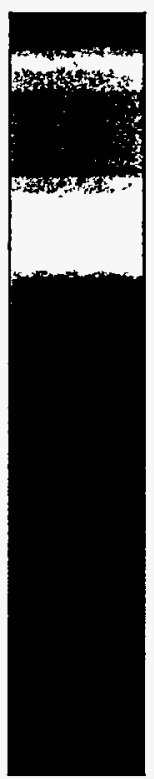

$\mathrm{T}=72$

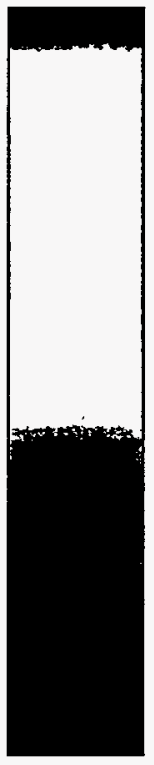

$\mathrm{T}=840$

Figure 12. Volumetric water content distributions with time (hours) for 5 to $2 \mathrm{~mm}$, over $<5 \mathrm{~mm}$ size fraction compacted at $83 \%$ maximum density assuming uniform flow. 

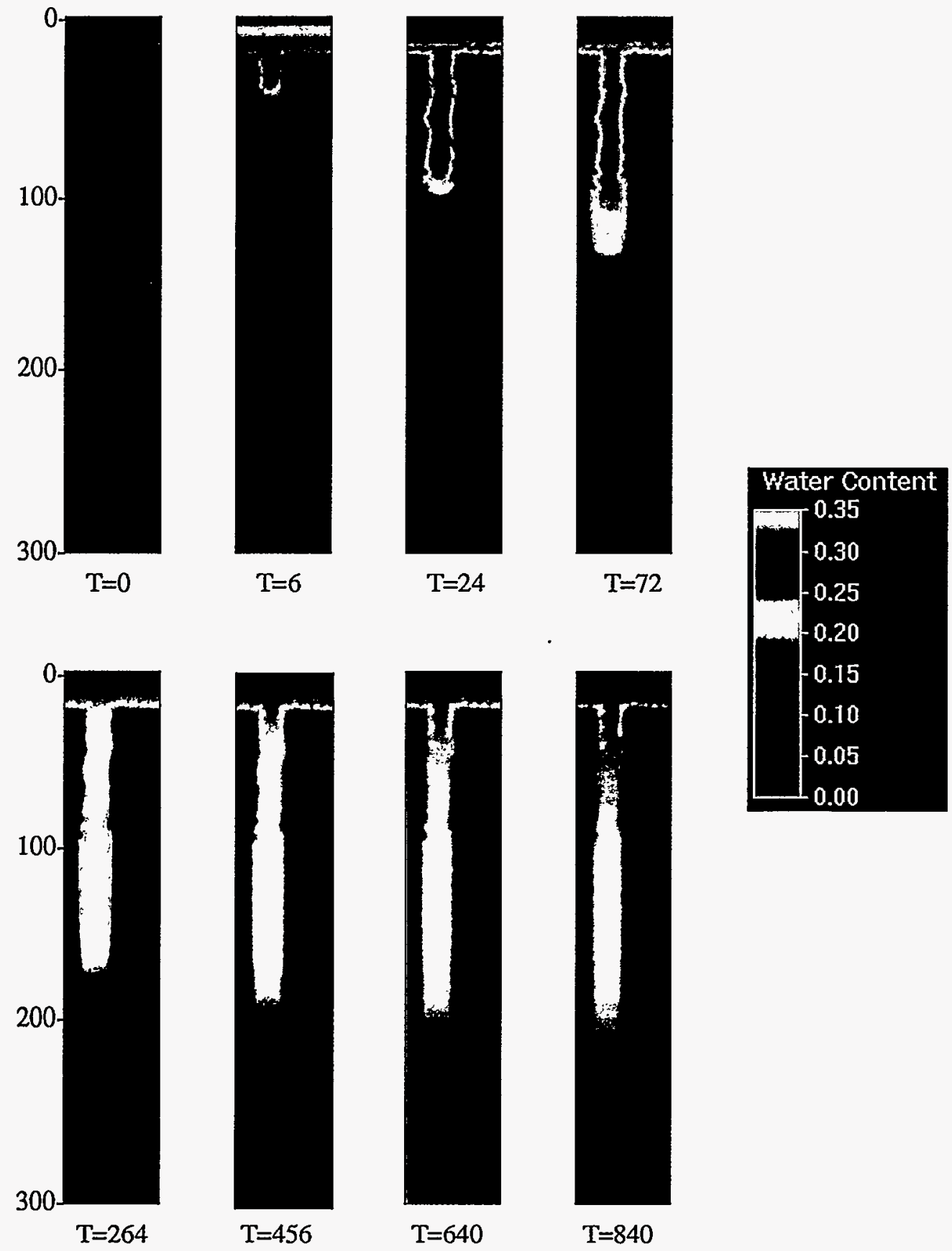

$\mathrm{T}=640$

$\mathrm{T}=840$

Figure 13. Volumetric water content distributions with time (hours) for 5 to $2 \mathrm{~mm}$, over $<5 \mathrm{~mm}$ size fraction compacted at $83 \%$ maximum density assuming preferential flow through 5\% CSA. 
Table 5. HYDRUS-2D Simulation Results from a Single 100-Year Storm Event for a Cover with Three Layers.

\begin{tabular}{|c|c|c|c|c|}
\hline Materials Order & $\begin{array}{c}\text { Layering } \\
\text { Depths (cm) }\end{array}$ & $\begin{array}{l}\text { Max. Infil. } \\
\text { Depth (cm), } \\
\text { Uniform Flow }\end{array}$ & $\begin{array}{l}\text { Max. Infil. Depth } \\
\text { (cm), Preferential } \\
\text { Flow }\end{array}$ & $\begin{array}{c}\text { Impact of } \\
\text { Preferential } \\
\text { Flow \% Change }\end{array}$ \\
\hline $\begin{array}{l}5 \text { to } 2 \mathrm{~mm} \text { over } \\
<19 \mathrm{~mm}-90 \% \text { over } \\
<19 \mathrm{~mm}-83 \%\end{array}$ & $\begin{array}{l}0 \text { to } 15 \\
15 \text { to } 45 \\
45 \text { to } 300\end{array}$ & 47 & 33 & $-29.8 \%$ \\
\hline $\begin{array}{l}5 \text { to } 2 \mathrm{~mm} \text { over } \\
<19 \mathrm{~mm}-83 \% \text { over } \\
<19 \mathrm{~mm}-90 \%\end{array}$ & $\begin{array}{l}0 \text { to } 15 \\
15 \text { to } 45 \\
45 \text { to } 300\end{array}$ & 60 & 52 & $-13.3 \%$ \\
\hline $\begin{array}{l}5 \text { to } 2 \mathrm{~mm} \text { over } \\
<5 \mathrm{~mm}-90 \% \text { over } \\
<5 \mathrm{~mm}-83 \%\end{array}$ & $\begin{array}{l}0 \text { to } 15 \\
15 \text { to } 45 \\
45 \text { to } 300\end{array}$ & 167 & 103 & $-38.3 \%$ \\
\hline $\begin{array}{l}5 \text { to } 2 \mathrm{~mm} \text { over } \\
<5 \mathrm{~mm}-83 \% \text { over } \\
<5 \mathrm{~mm}-90 \%\end{array}$ & $\begin{array}{l}0 \text { to } 15 \\
15 \text { to } 45 \\
45 \text { to } 300\end{array}$ & 152 & 118 & $-22.4 \%$ \\
\hline $\begin{array}{l}5 \text { to } 2 \mathrm{~mm} \text { over } \\
<2 \mathrm{~mm}-90 \% \text { over } \\
<2 \mathrm{~mm}-83 \%\end{array}$ & $\begin{array}{l}0 \text { to } 15 \\
15 \text { to } 45 \\
45 \text { to } 300\end{array}$ & 103 & 60 & $-38.8 \%$ \\
\hline $\begin{array}{l}5 \text { to } 2 \mathrm{~mm} \text { over } \\
<2 \mathrm{~mm}-83 \% \text { over } \\
<2 \mathrm{~mm}-90 \%\end{array}$ & $\begin{array}{l}0 \text { to } 15 \\
15 \text { to } 45 \\
45 \text { to } 300\end{array}$ & 122 & 70 & $-42.6 \%$ \\
\hline
\end{tabular}

The two-layer simulations, i.e., monofil cover, suggest that a 2-m cover thickness compacted to $83 \%$ maximum density is adequate if flow is uniform. The main justification for layering is the disruption of preferential flowpaths both from a plant-root intrusion and unstable-funnel flowpath. According to the three-layer simulations, this can be accomplished without large contrasts in compaction or soil texture but with layers of subtle contrast. This scenario was tested for each treatment with the root-zone and sub-base material being compacted at the $83 \%$ maximum density with a single lift $(15 \mathrm{~cm})$ of the same texture compacted at the $90 \%$ maximum density in between. This combination provided the most promising results (Table 6) with a $47 \%$ reduction in infiltration depth for the preferential flow scenarios. Assuming that flow is uniform, the depth of infiltration is not reduced by this $15-\mathrm{cm}$ layer compacted at $90 \%$ maximum density when compared to the threelayer case in which this layer extends to $300 \mathrm{~cm}$ (Figures 16,17 and 18). The benefit, however, of disrupting preferential flowpaths is obvious (Figures 19, 20 and 21). It is also apparent in the preferential flow simulations that the lateral flow due to this disruption in a finger flowpath is not significant enough to be concerned with movement into differential subsidence fissures. Such a fissure would have to be in close proximity to the flow finger for any appreciable quantity of infiltration to be diverted into it. 


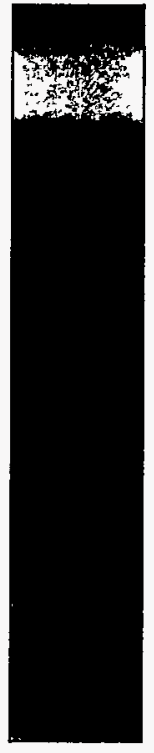

$\mathrm{T}=0$

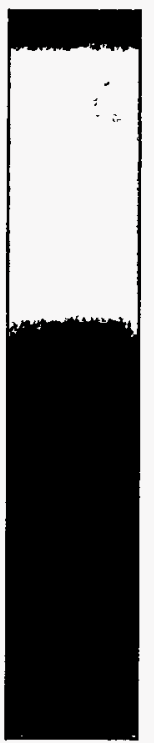

$\mathrm{T}=264$

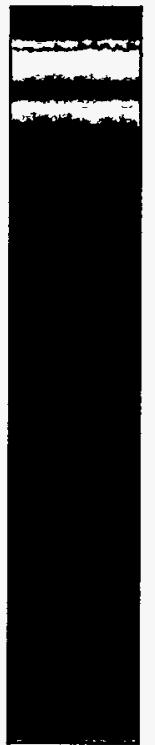

$\mathrm{T}=6$

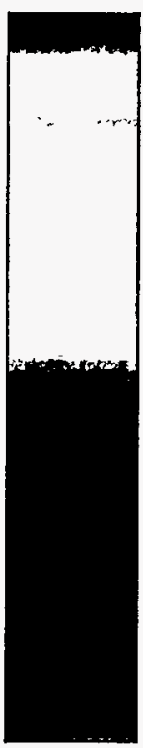

$\mathrm{T}=456$

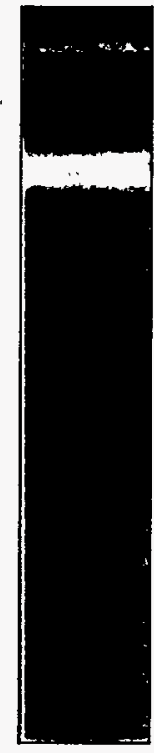

$\mathrm{T}=24$

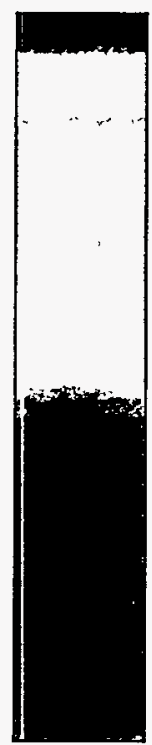

$\mathrm{T}=640$

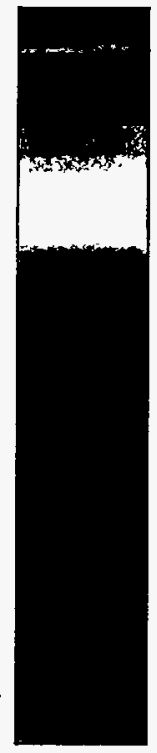

$\mathrm{T}=72$

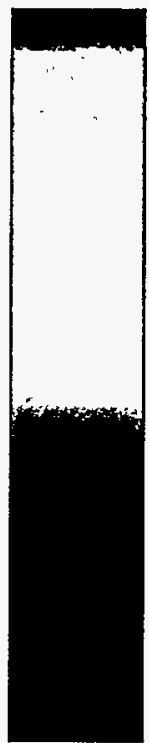

$\mathrm{T}=840$

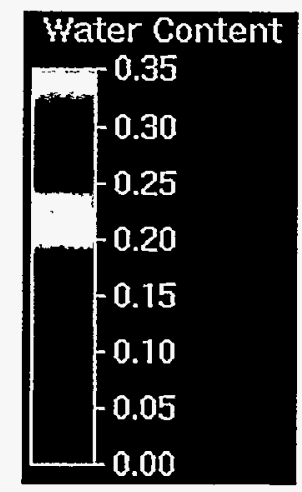

Figure 14. Volumetric water content distributions with time (hours) for 5 to $2 \mathrm{~mm}$, over layers of $<5 \mathrm{~mm}$ size fraction compacted at $90 \%$, and $83 \%$ maximum density, respectively, assuming uniform flow. 

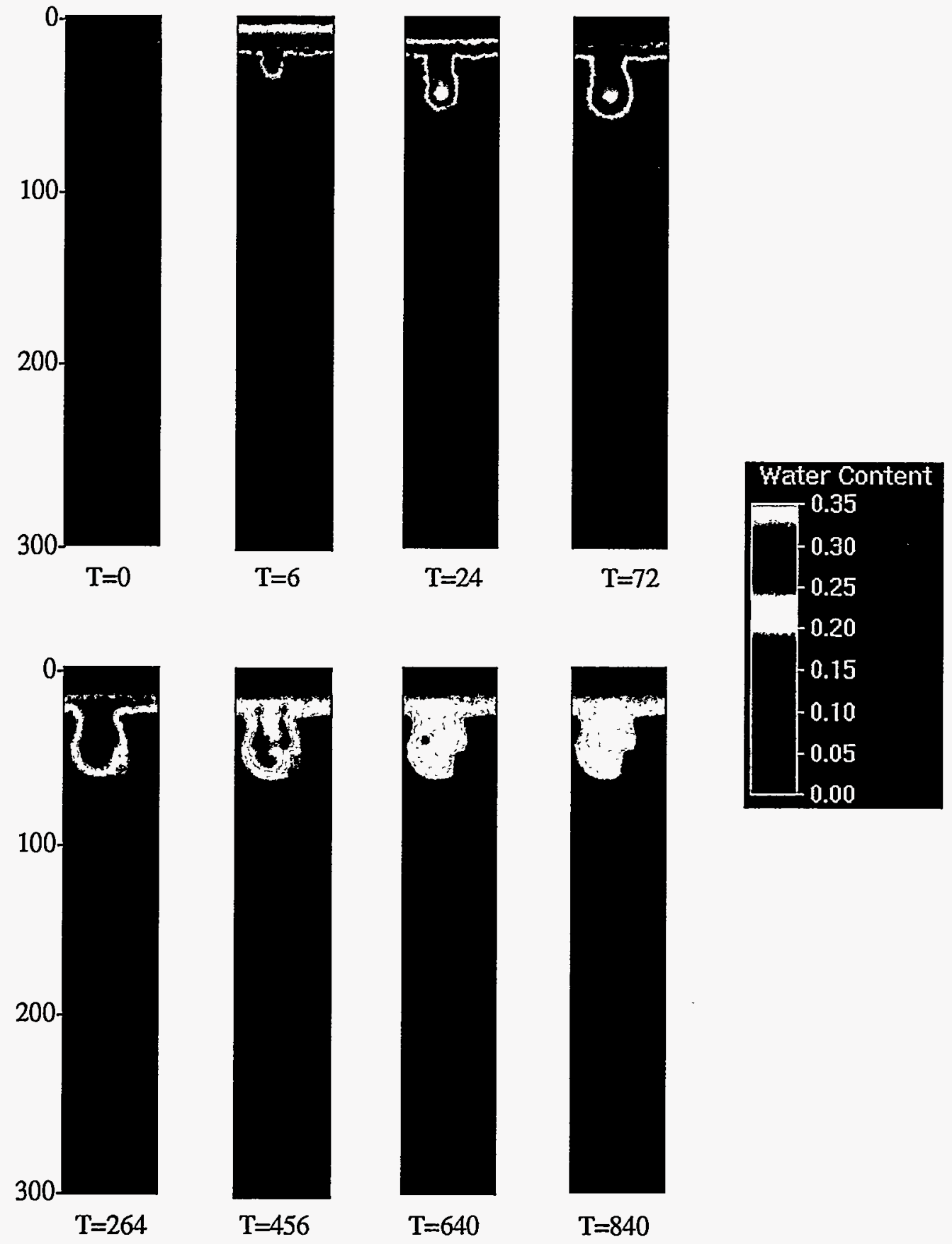

Figure 15. Volumetric water content distributions with time (hours) for 5 to $2 \mathrm{~mm}$, over layers of $<5 \mathrm{~mm}$ size fraction compacted at $90 \%$, and $83 \%$ maximum density, respectively, assuming preferential flow through 5\% CSA. 
Table 6. HYDRUS-2D Simulation Results from a Single 100-Year Storm Event for a Cover with Four Layers.

\begin{tabular}{|c|c|c|c|c|}
\hline Materials Order & $\begin{array}{c}\text { Layering } \\
\text { Depths }(\mathrm{cm})\end{array}$ & $\begin{array}{l}\text { Max. Infil. } \\
\text { Depth (cm), } \\
\text { Uniform Flow }\end{array}$ & $\begin{array}{l}\text { Max. Infil. Depth } \\
\text { (cm), Preferential } \\
\quad \text { Flow }\end{array}$ & $\begin{array}{c}\text { Impact of } \\
\text { Preferential Flow } \\
\text { \% Change }\end{array}$ \\
\hline $\begin{array}{l}5 \text { to } 2 \mathrm{~mm} \text { over } \\
<19 \mathrm{~mm}-83 \% \text { over } \\
<19 \mathrm{~mm}-90 \% \text { over } \\
<19 \mathrm{~mm}-83 \%\end{array}$ & $\begin{array}{l}0 \text { to } 15 \\
15 \text { to } 45 \\
45 \text { to } 60 \\
60 \text { to } 300\end{array}$ & 83 & 52 & $-37.3 \%$ \\
\hline $\begin{array}{l}5 \text { to } 2 \mathrm{~mm} \text { over } \\
<5 \mathrm{~mm}-83 \% \text { over } \\
<5 \mathrm{~mm}-90 \% \text { over } \\
<5 \mathrm{~mm}-83 \%\end{array}$ & $\begin{array}{l}0 \text { to } 15 \\
15 \text { to } 45 \\
45 \text { to } 60 \\
60 \text { to } 300\end{array}$ & 174 & 66 & $-62.1 \%$ \\
\hline $\begin{array}{l}5 \text { to } 2 \mathrm{~mm} \text { over } \\
<2 \mathrm{~mm}-83 \% \text { over } \\
<2 \mathrm{~mm}-90 \% \text { over } \\
<2 \mathrm{~mm}-83 \%\end{array}$ & $\begin{array}{l}0 \text { to } 15 \\
15 \text { to } 45 \\
45 \text { to } 60 \\
60 \text { to } 300\end{array}$ & 112 & 65 & $-42.0 \%$ \\
\hline
\end{tabular}

(text continues on page 32) 

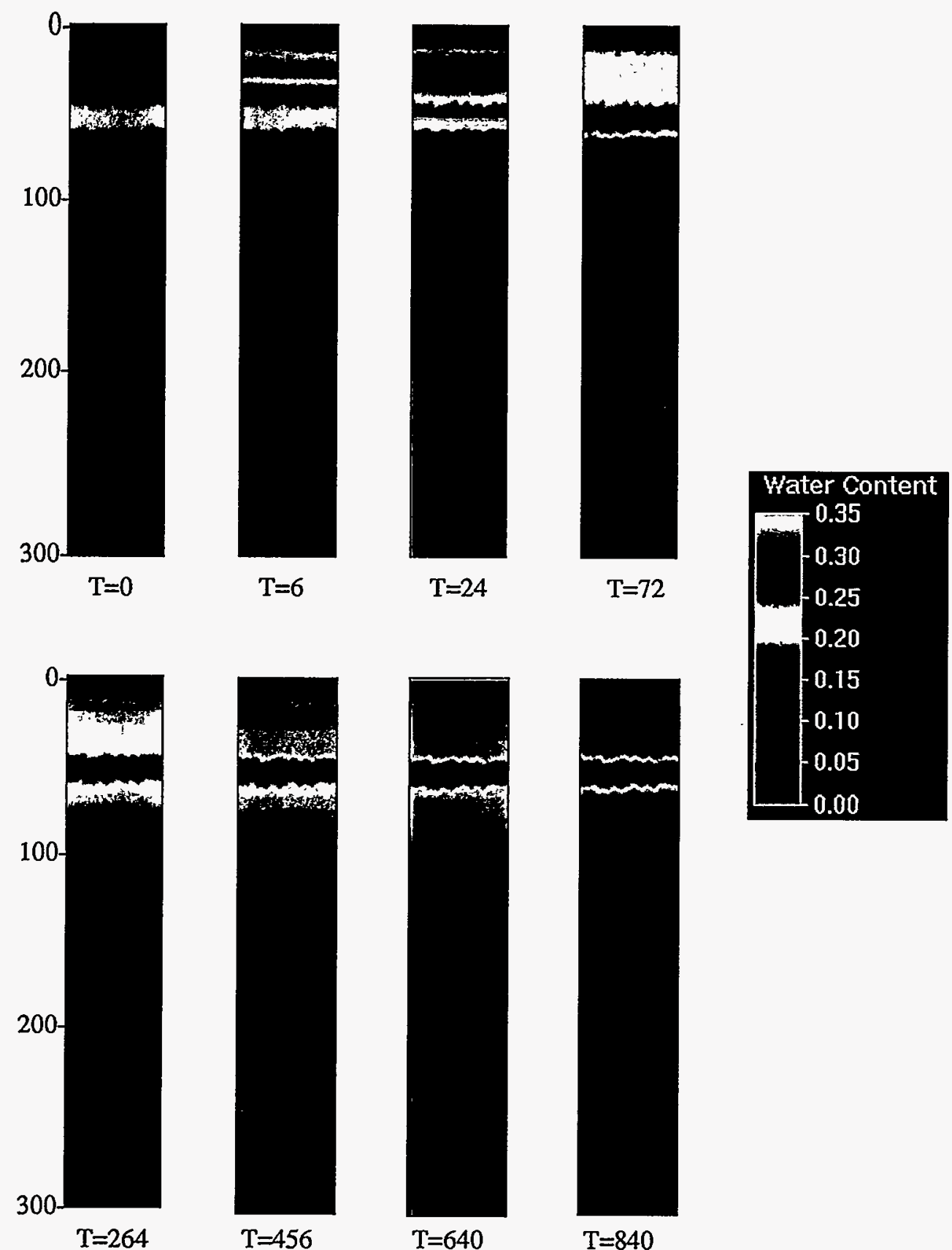

$\mathrm{T}=264$

$\mathrm{T}=456$

$\mathrm{T}=640$

$T=840$

Figure 16. Volumetric water content distributions with time (hours) for 5 to $2 \mathrm{~mm}$, over layers of $<19 \mathrm{~mm}$ size fraction compacted at $83 \%, 90 \%$, and $83 \%$ maximum density, respectively, assuming uniform flow. 


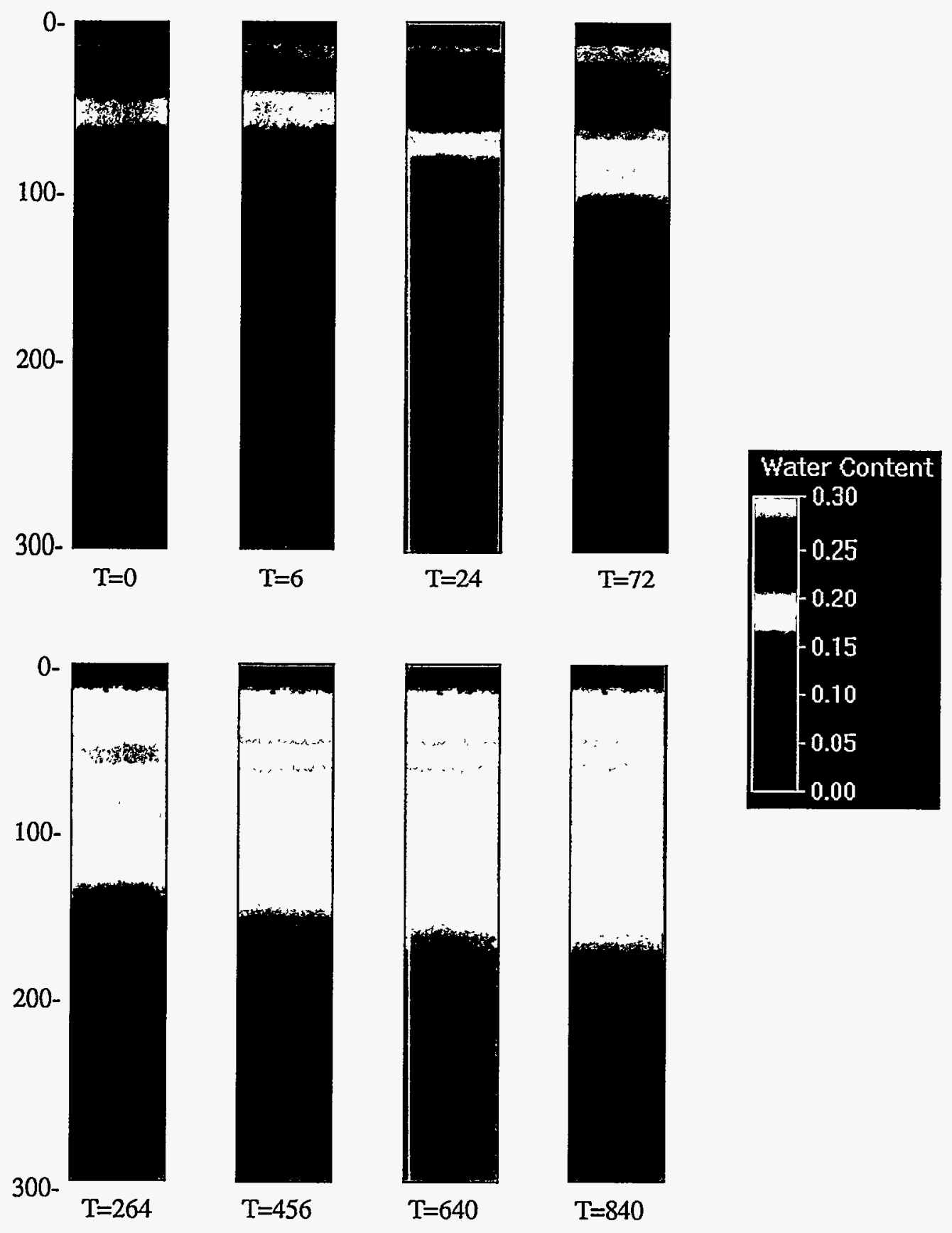

Figure 17. Volumetric water content distributions with time (hours) for 5 to $2 \mathrm{~mm}$, over layers of $<5 \mathrm{~mm}$ size fraction compacted at $83 \%, 90 \%$, and $83 \%$ maximum density, respectively, assuming uniform flow. 

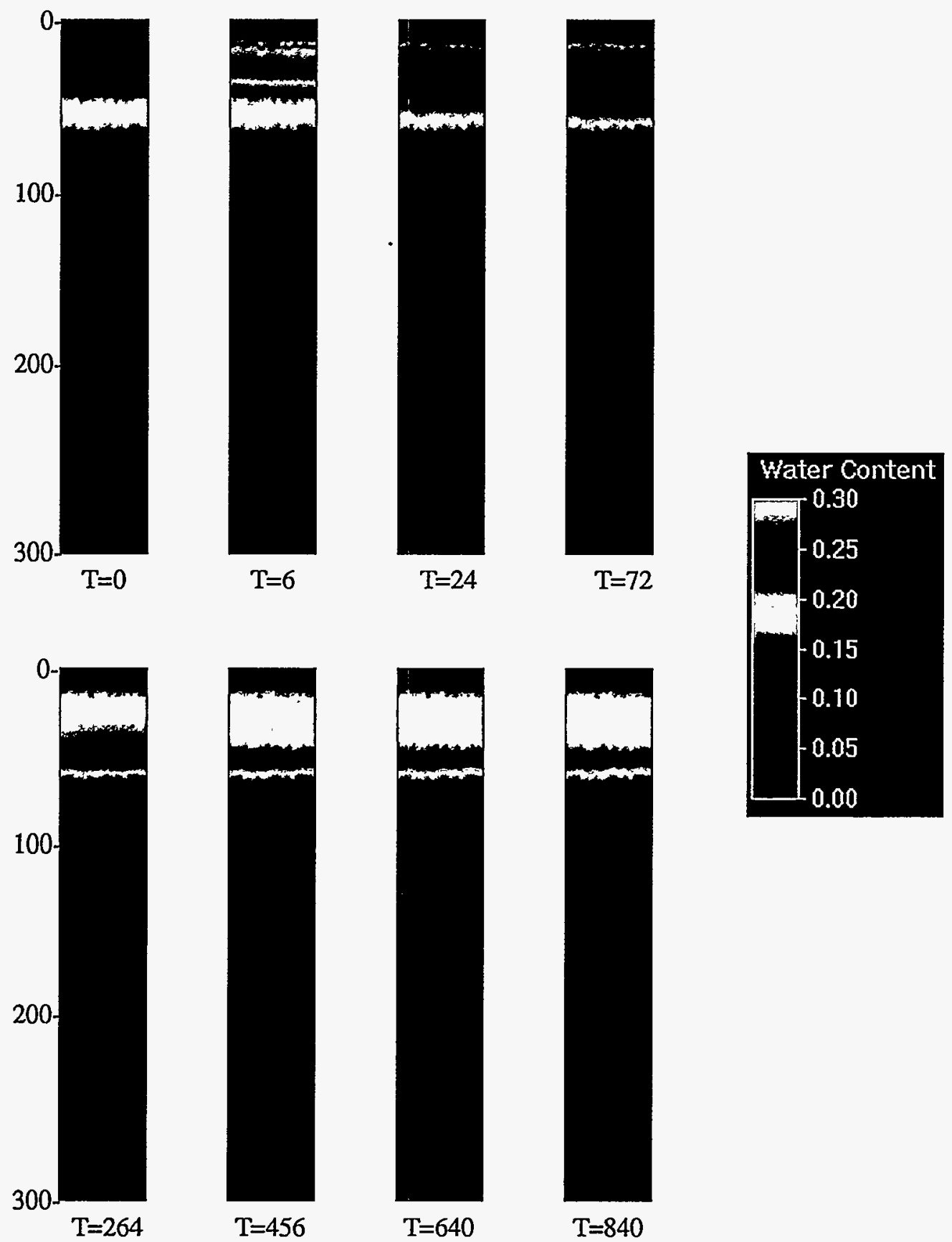

Figure 18. Volumetric water content distributions with time (hours) for 5 to $2 \mathrm{~mm}$, over layers of $<2 \mathrm{~m}$ size fraction compacted at $83 \%, 90 \%$, and $83 \%$ maximum density, respectively, assuming uniform flow. 

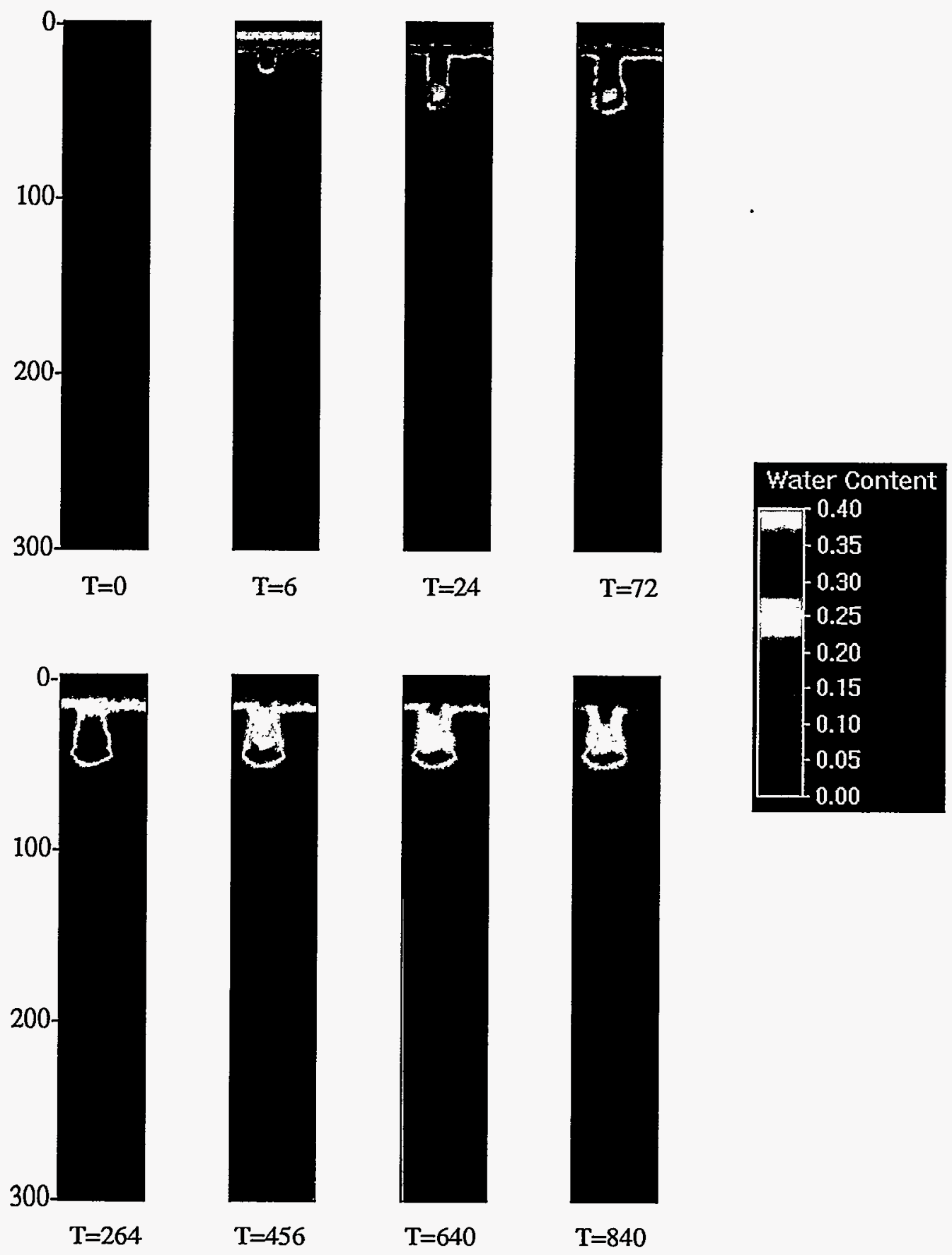

Figure 19. Volumetric water content distributions with time (hours) for 5 to $2 \mathrm{~mm}$, over layers of $<19 \mathrm{~mm}$ size fraction compacted at $83 \%, 90 \%$, and $83 \%$ maximum density, respectively, assuming preferential flow through 5\% CSA. 

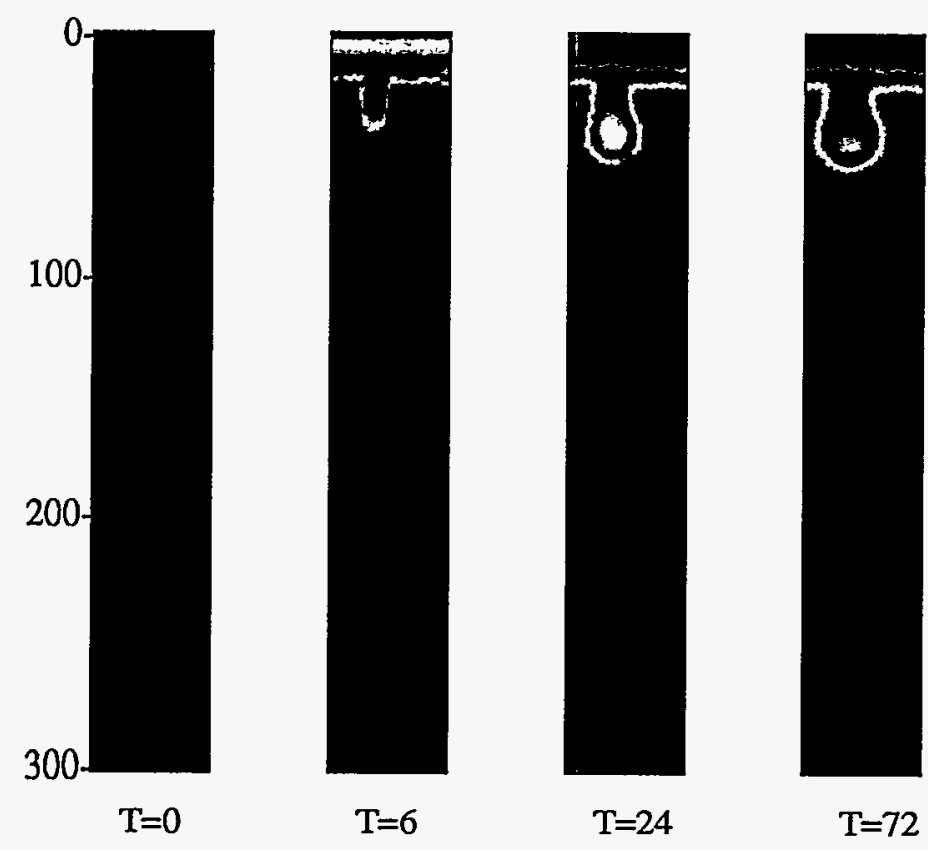

Water Content
0.35
0.30
0.25
0.20
0.15
0.10
-0.05
0.00
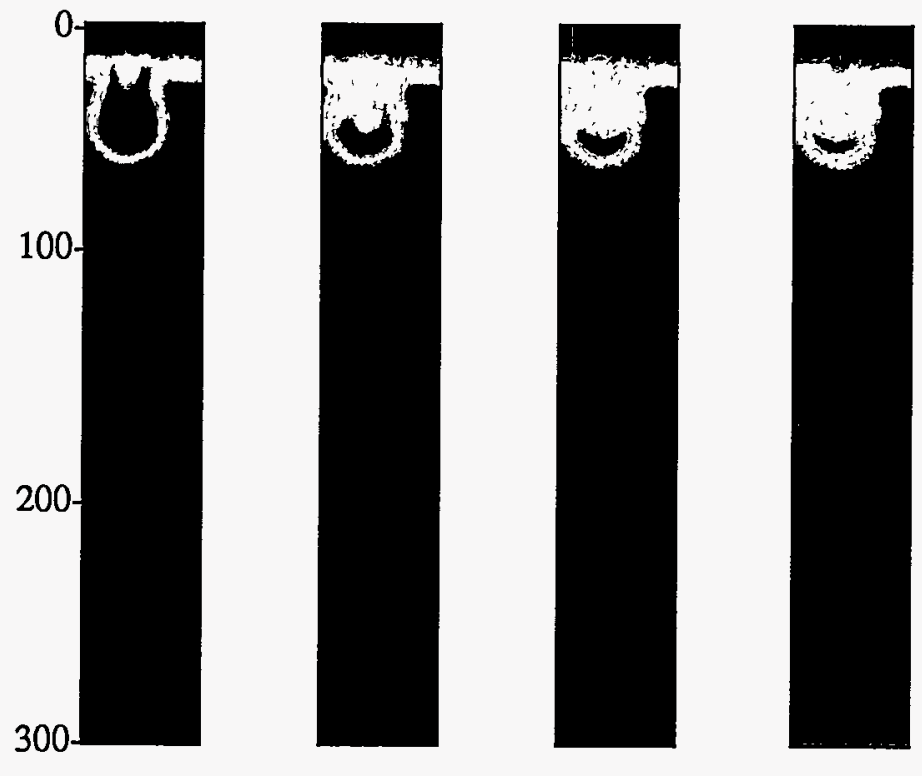

$\mathrm{T}=72$

$\mathrm{T}=24$

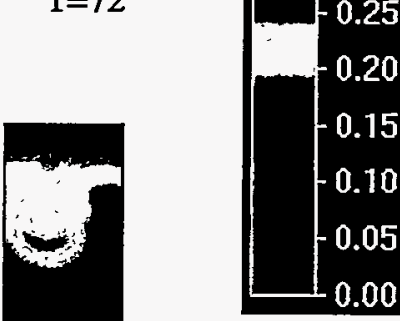

$\mathrm{T}=264$

$\mathrm{T}=456$

$\mathrm{T}=640$

$\mathrm{T}=840$

Figure 20. Volumetric water content distributions with time (hours) for 5 to $2 \mathrm{~mm}$, over layers of $<5 \mathrm{~mm}$ size fraction compacted at $83 \%, 90 \%$, and $83 \%$ maximum density, respectively, assuming preferential flow through 5\% CSA. 


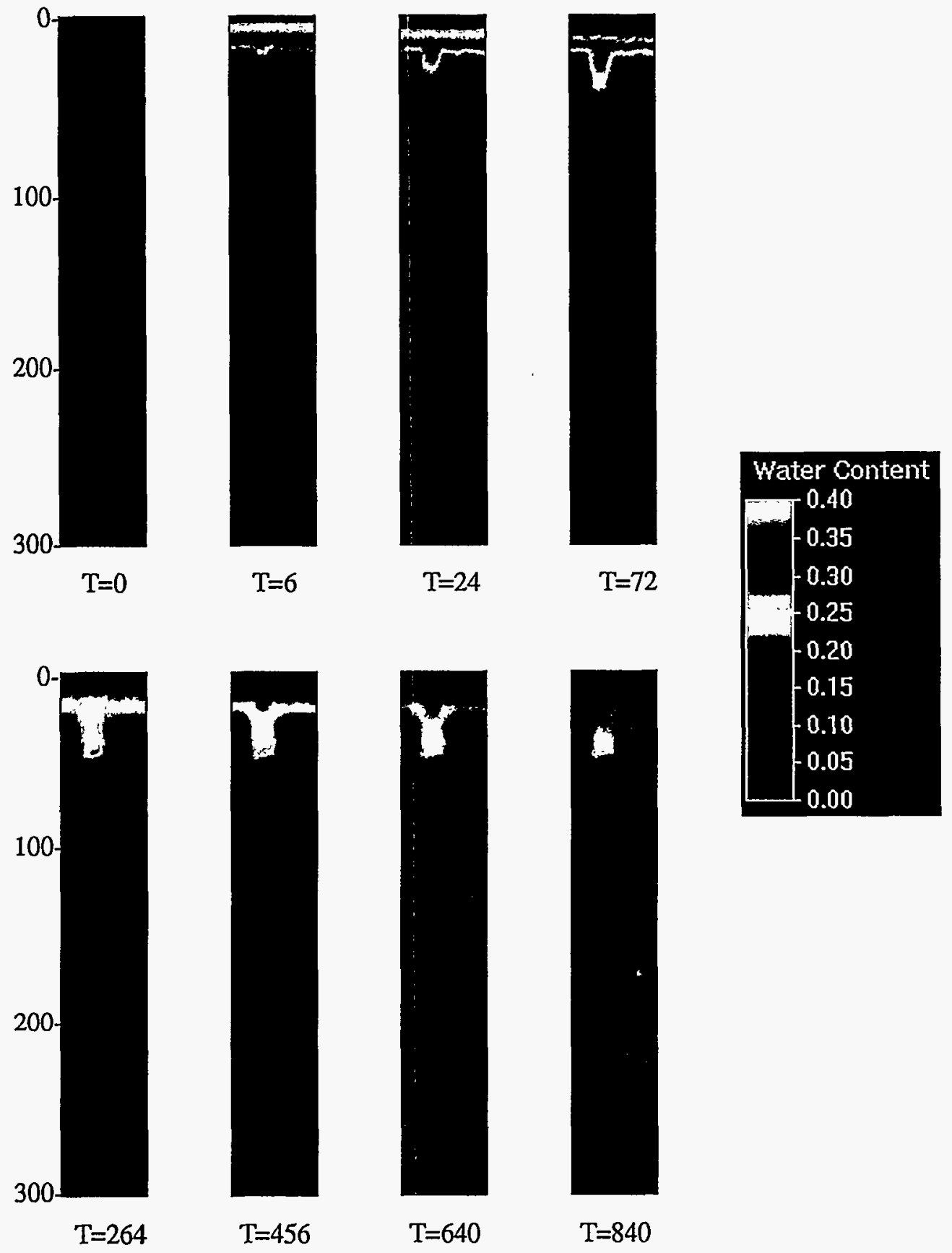

Figure 21. Volumetric water content distributions with time (hours) for 5 to $2 \mathrm{~mm}$, over layers of $<2 \mathrm{~mm}$ size fraction compacted at $83 \%, 90 \%$, and $83 \%$ maximum density, respectively, assuming preferential flow through $5 \%$ CSA. 

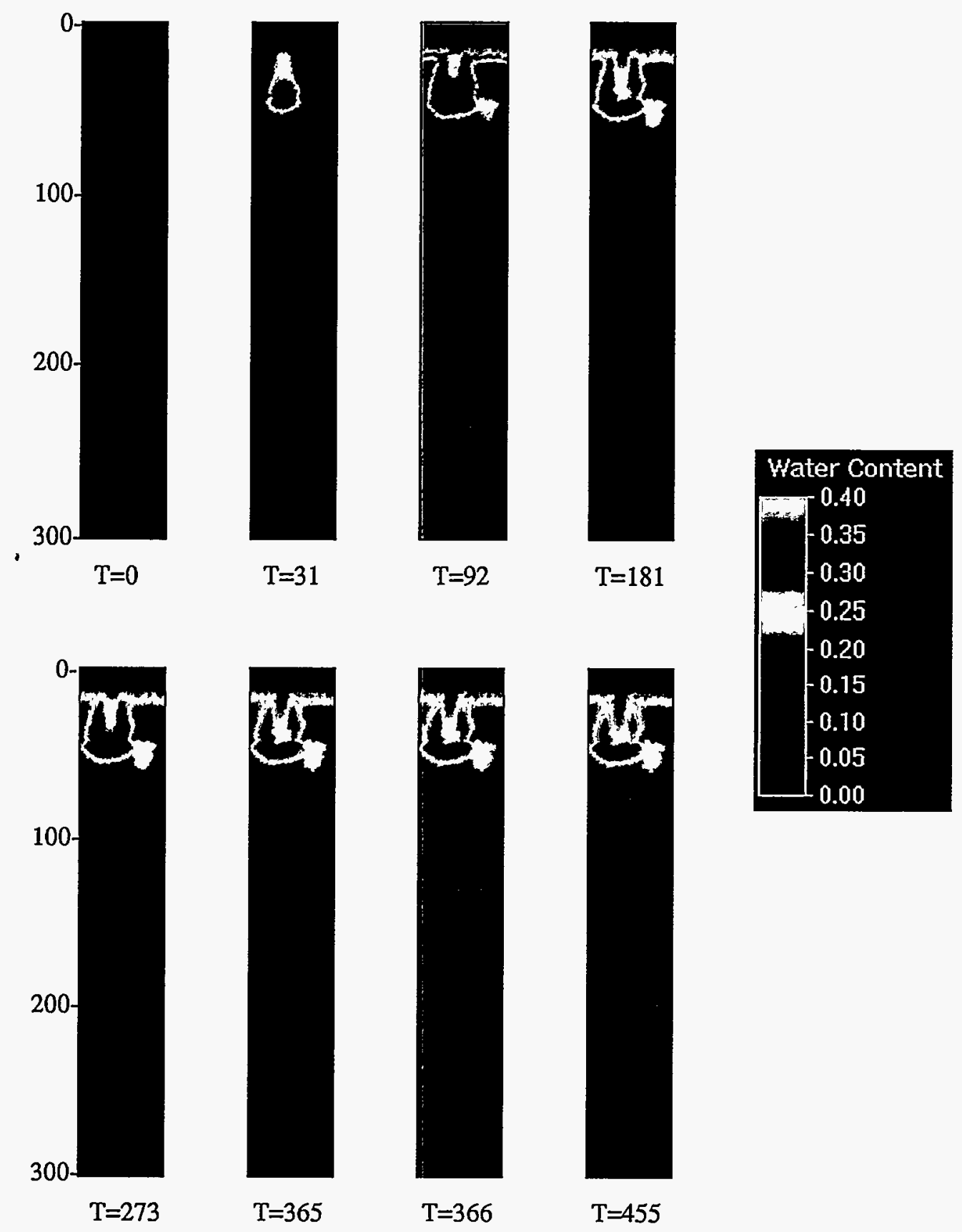

Figure 22. Volumetric water content distributions with time (days) for 5 to $2 \mathrm{~mm}$, over layers of $<19 \mathrm{~mm}$ size fraction compacted at $83 \%,<2 \mathrm{~mm}$ size fraction compacted to $90 \%$, and $<19 \mathrm{~mm}$ size fraction compacted $83 \%$ maximum density, assuming preferential flow through $5 \%$ CSA. 


\section{REFERENCES}

Allison, G.B., G.W. Gee and S.W. Tyler, 1994. Vadose zone techniques for estimating groundwater recharge in arid and semiarid regions. Soil Sci. Soc. Am. J. 58:6-14.

Anderson, J., 1997. Soil-plant cover systems for final closure of solid waste landfills in arid regions. Landfill Capping in the Semi-Arid West: Problems, Perspectives, and Solutions. (Eds) T.D. Reynolds and R.C. Morris. May 1997, Environ. Sci. and Res. Foundation, Idaho Falls, D. pp. 27-38.

Ankeny, M.D., L.M. Coons, N. Majumdar, J. Kelly and M. Miller, 1997. Performance and cost considerations for landfill caps in semiarid climates. Landfill Capping in the Semi-Arid West: Problems, Perspectives, and Solutions. (Eds) T.D. Reynolds and R.C. Morris. May 1997, Environ. Sci. and Res. Foundation, Idaho Falls, ID. pp. 243-262.

Arnold, B., T. Brown, J. Cochran, B. Crowe, B. Gilbert, B. Luke, F. Shuri, E. Strassburger, G. Wilson and S. Wirth, 1997. Consequences of Subsidence for the Area 3 and Area 5 Radioactive Waste Management Sites, Nevada Test Site (Working Group Report). U.S. Dept. of Energy, Nevada Operations Office (in draft).

ASTM D 422-63 (90), 1990. Standard method for particle size analysis of soils. Annual Book of ASTM Standards, Vol 04.08, American Soc. for Testing and Materials, Philadelphia, PA.

ASTM D 1557-91, 1992. Test method for laboratory compaction characteristics of soil using modified effort. Annual Book of ASTM Standards, Vol 04.08, American Soc. for Testing and Materials, Philadelphia, PA.

Beven, K. and P. Germann, 1982. Macropores and water flow in soils. Water Resour. Res. 18:13111325 .

Dwyer, S.F., 1997. Large-scale field study of landfill covers at Sandia National Laboratories. Landfill Capping in the Semi-Arid West: Problems, Perspectives, and Solutions. (Eds) T.D. Reynolds and R.C. Morris. May 1997, Environ. Sci. and Res. Foundation, Idaho Falls, D. pp. 87-107.

Edwards, W.M., L.D. Norton and M.J. Shipitalo, 1987. Effect of macroporosity on infiltration into no-till corn watersheds. EOS Trans. Am. Geophys. Union 68:313.

Fayer, M.J., G.W. Gee, M.L. Rockhold, M.D. Freshly and T.B. Walters, 1996. Estimating recharge rates for a groundwater model using GIS. J. Environ. Qual. 25:510-518.

Fernald, A.T., 1974. Geology and material properties of the Area 3 "Sand Pile," Southeastern Yucca Flat, Nevada Test Site, Part I-Geology. U.S. Geological Survey, Special Projects Branch.

Gee, G.W., M.J. Fayer, M.L. Rockhold and M.D. Campbell, 1992. Variations in recharge at the Hanford site. Northwest Sci. 66:237-250. 
Gee, G.W., P.J. Wierenga, B.J. Andraski, M.H. Young, M.J. Fayer and M.L. Rockhold, 1994. Variations in water balance and recharge potential at three western desert sites. Soil Sci. Soc. Am. J. 58:63-72.

Gee, G.W. and A. Ward, 1997. Still in quest of the perfect cap. Landfill Capping in the Semi-Arid West: Problems, Perspectives, and Solutions. (Eds) T.D. Reynolds and R.C. Morris. May 1997, Environ. Sci. and Res. Foundation, Idaho Falls, D. pp. 145-164.

Ginanni, J.M., L.J. O’Neill, D.P. Hammermeister, D.O. Blout, B.L. Dozier, M.J. Sully, K.R. Johnejack, D.F. Emer and S.W. Tyler, 1993. Hydrogeologic characterization of an arid zone radioactive waste management site. $15^{\text {th }}$ Annual U.S. Department of Energy Low-Level Radioactive Waste Management Conference. Phoenix, AZ. Dec. 1-3, 1993.

Hokett, S. and R.H. French, 1997. Evaluation of recharge potential at Crater U5a. Water Resources Center, Desert Research Institute, Publication No. 45160 (draft).

Holmes and Narver, 1962. Station U3b 1: Portion of Area 3 Post Test topography. 1:480 scale, $2 \mathrm{ft}$ countour interval. In: Schmeltzer, J.S., D.O. Blout, K.A. Zukosky, and D.P. Hammermeister. 1994. Archival literature search and conceptual model for the U3ax/bl disposal unit, NTS Nye County, Nevada. Reynolds Electrical \& Engineering Co., Inc., Las Vegas, NV (draft).

Istok, J.D., D.O. Blout, L. Barker, K.R. Johnejack and D.P. Hammermeister, 1994. Spatial variability in alluvium properties at a low-level nuclear waste site. Soil Sci. Soc. Am. J., 58:1040-1051.

Johnejack, K.R., D.O. Blout, M.J. Sully, D.F. Emer, D.P. Hammermeister, L.G. Dever, L.J. O'Neill, S.W. Tyler and J. Chapman, 1994. Significance of water fluxes in a deep arid-region vadose zone to waste disposal strategies. IN: WM'94, Working Towards a Cleaner Environment: Waste Processing, Transportation, Storage, and Disposal, Technical Programs and Public Education. (Eds.) R.G. Post and M.E. Wacks, Proceedings of the Symposium on Waste Management, Tucson, AZ, Feb. 27-March 3, 1994, II: 949-956.

Johnejack, K.R., D.G. Levitt, M.J. Sully, J.P. Angerer, V.K. Winkle, D.C. Anderson, K.W. Blomquist and D.B. Hall, 1995. Integrated closure program for the Area 3 and Area 5 radioactive waste management sites Nevada Test Site. U.S. Department of Energy, draft report.

Kinsall, B.L., G.V. Wilson, A.V. Palumbo and T.J. Phelps, 1997. Soil property influences on heterogeneity in unsaturated flow and microbial transport through undisturbed soil blocks. Soil Sci. Soc. Am. J. (in review).

Klute, A., 1986. Water retention: Laboratory methods. In: Methods of Soil Analysis. Part 1. Physical and Mineralogical Methods. (Ed.) A. Klute. Agronomy Monograph No. 9., American Society of Agronomy, Madison, WI, pp. 635-660.

Klute, A. and C. Dirksen, 1986. Hydraulic conductivity and diffusivity: Laboratory methods. In: Methods of Soil Analysis. Part 1. Physical and Mineralogical Methods. (Ed.) A. Klute. Agronomy Monograph No. 9., American Society of Agronomy, Madison, WI, pp. 687-732. 
Kung, K.-J.S., 1990. Preferential flow in a sandy vadose zone: 1. Field observation. Geoderma 46:51-58.

Miller, J.F., R.H. Frederick and R.J. Tracey, 1973. Precipitation-frequency atlas of the Western United States. NOAA Atlas 2, Volume VII-Nevada, U.S. Gov. Printing Office, Washington D.C. Stock Number 0317-00161.

Schmeltzer, J.S., D.O. Blout, K.A. Zukosky and D.P. Hammermeister, 1994. Archival literature search and conceptual model for the U3ax/bl disposal unit, NTS Nye County, Nevada. Reynolds Electrical \& Engineering Co., Inc., Las Vegas, NV (draft).

Shott, G. J., C.J. Muller, L.E. Barker, D.E. Cawlfield, F.T. Lindstrom, D.G. Linkenheil, M.J. Sully, L. McDowell-Boyer and D.J. Thorne, 1995. Performance Assessment for the Area 5 Radioactive Waste Management Site at the Nevada Test Site, Nye County, Nevada. DOE/NV/11432-196.

Simunek, J., M. Sejna and M.T. van Genuchten, 1996. HYDRUS-2D: Simulating water flow and solute transport in two-dimensional variably saturated media. International Groundwater Modeling Center, Colorado School of Mines, Golden, CO.

Skahn, K., 1997. EPA's performance, monitoring, and maintenance requirements for landfill caps. Landfill Capping in the Semi-Arid West: Problems, Perspectives, and Solutions. (Eds) T.D. Reynolds and R.C. Morris. May 1997, Environ. Sci. and Res. Foundation, Idaho Falls, ID. pp. 19-26.

Tyler, S.W. and G.S. Walker, 1994. Root zone effects on tracer migration in arid zones. Soil Sci. Soc. Am. J. 58:25-31.

Tyler, S.W., J.B. Chapman, S.H. Conrad, D.P. Hammermeister, D.O. Blout, J.J. Miller, M.J. Sully and J.M. Ginanni, 1996. Soil-water flux in the southern Great Basin, United States: Temporal and spatial variations over the last 120,000 years. Water Resources Res., 32:1481-1499.

van Genuchten, M.T., 1980. A closed-form equation for predicting the hydraulic conductivity of unsaturated soils. Soil Sci. Soc. Am. J., 44, pp.892-898.

Waugh, W.J., 1997. Summary of the Subsurface Contaminant Focus Area Workshop on Long-Term Performance of Landfill Covers. Park City, Utah, June 26, 1996, Roy F. Weston, Inc., Grand Junction, $\mathrm{CO}$.

Wilson, G.V. and R.J. Luxmoore, 1988. Infiltration, macroporosity, and mesoporosity distributions on two forested watersheds. Soil Sci. Soc. Am. J., 52:329-335.

Wilson, G.V., B.L. Kinsall, A.V. Palumbo and R.S. Burlage, 1997. Heterogeneity in physical and hydraulic properties control the unsaturated microbial transport through a vadose zone. $J$. Environ. Qual., (in review). 


\section{Appendix A}

Particle Size Analysis Data 
Table A-1. Particle Size Analysis

NTS Area 3 - Particle Size Analysis $>>$ Wet Sieve Method (>0.080 mm)

Date: 6/26/97 By: Maren Henley

Dry Wt. of total sample: $207.6 \mathrm{lb}(94,184 \mathrm{~g})$

Dry Wt. of sample used in sieving: $1493.6 \mathrm{~g}$

\begin{tabular}{lcccc}
\hline Sieve Size & $\begin{array}{c}\text { Ind. Weight } \\
\text { Retained }(\mathrm{g})\end{array}$ & $\begin{array}{c}\text { Weight } \\
\text { Retained } \\
\text { Cumulative }(\mathrm{g})\end{array}$ & $\begin{array}{c}\text { Cumulative \% } \\
\text { Finer }-3 / 4 \\
\text { Portion }\end{array}$ & $\begin{array}{c}\text { Normalized } \\
\text { Cumulative \% } \\
\text { Finer }\end{array}$ \\
\hline 3 in. $(76.2 \mathrm{~mm})$ & 0 & & & 100.0 \\
2-1/2 in. $(63.5 \mathrm{~mm})$ & 0 & & & 100.0 \\
2 in. $(50.8 \mathrm{~mm})$ & 472 & 472 & & 99.5 \\
$1-1 / 2$ in. $(38.1 \mathrm{~mm})$ & 400 & 872 & & 99.1 \\
1 in. $(25.4 \mathrm{~mm})$ & 1191 & 2063 & & 97.8 \\
$3 / 4$ in. $(19.1 \mathrm{~mm})$ & 1502 & 3565 & 95.9 & 96.2 \\
$1 / 2$ in. $(12.7 \mathrm{~mm})$ & & 61.53 & 91.4 & 92.2 \\
$3 / 8$ in. $(9.53 \mathrm{~mm})$ & & 128.62 & 81.8 & 78.7 \\
sieve \#4 $(5.0 \mathrm{~mm})$ & & 271.30 & 68.2 & 65.6 \\
sieve \#10 $(2.0 \mathrm{~mm})$ & & 474.33 & 56.8 & 54.6 \\
sieve \#16 $(1.18 \mathrm{~mm})$ & & 645.89 & 45.7 & 44.0 \\
sieve \#20 $(.850 \mathrm{~mm})$ & & 810.68 & 35.8 & 34.5 \\
sieve \#60 $(.250 \mathrm{~mm})$ & & 958.20 & 26.6 & 25.6 \\
sieve \#100 $(.150 \mathrm{~mm})$ & & 1095.69 & 17.9 & 17.2 \\
sieve \#200 $(.080 \mathrm{~mm})$ & & 1226.36 & & \\
\hline
\end{tabular}


Table A-2.1. Hydrometer Analysis: Trial 1

Particle Size Analysis -> Sieve Analysis of Hydrometer Method: > No. 230 Sieve Trial 1 By: Maren Henley

Sample Name: NTS Area $3<$ No. 10 Standard U.S. Sieve

Mass of Transfer Beaker: $10 \mathrm{~g}$

Mass of Wet Soil and Beaker: $50 \mathrm{~g}$

Mass of Wet Soil: $40 \mathrm{~g}$

Adjusted Dry Mass of Soil: $38.11 \mathrm{~g}$

\begin{tabular}{ccccc}
\hline Time (min) & $\begin{array}{c}\text { Blank Hydrometer } \\
\text { Reading }\end{array}$ & $\begin{array}{c}\text { Blank Solution } \\
\text { Temperature }{ }^{\circ} \mathrm{C}\end{array}$ & $\begin{array}{c}\text { Soil Hydrometer } \\
\text { Reading }\end{array}$ & $\begin{array}{c}\text { Soil Solution } \\
\text { Temperature }{ }^{\circ} \mathrm{C}\end{array}$ \\
\hline 0.5 & 6.0 & 20.2 & 17.0 & 20.2 \\
1 & 6.0 & 20.2 & 16.0 & 20.2 \\
3 & 6.0 & 20.3 & 14.5 & 20.3 \\
10 & 6.0 & 20.4 & 13.5 & 20.4 \\
30 & 6.0 & 20.7 & 12.0 & 20.7 \\
60 & 6.0 & 21.0 & 11.5 & 21.0 \\
90 & 6.0 & 21.3 & 11.0 & 21.3 \\
120 & 5.5 & 21.5 & 10.9 & 21.5 \\
1440 & 6.0 & 21.8 & 9.0 & 21.8 \\
\hline
\end{tabular}

Mass of Transfer Beaker: $12.42 \mathrm{~g}$

Mass of Beaker and Sand: $37.52 \mathrm{~g}$

Mass of Sand: $25.1 \mathrm{~g}$

Mass of Clay and Silt: $13.01 \mathrm{~g}$

\begin{tabular}{lcccccc}
\hline $\begin{array}{l}\text { Sieve Size } \\
\text { (micrometer) }\end{array}$ & $\begin{array}{c}\text { Sieve } \\
\text { Mass } \\
(\mathrm{g})\end{array}$ & $\begin{array}{c}\text { Sieve and } \\
\text { Soil Mass } \\
(\mathrm{g})\end{array}$ & $\begin{array}{c}\text { Soil } \\
\text { Fraction } \\
\text { Mass (g) }\end{array}$ & $\begin{array}{c}\text { \% of } \\
\text { Sample }\end{array}$ & $\begin{array}{c}\text { \% Sample } \\
\text { Adjusted for } \\
\text { Sample Loss }\end{array}$ & \% Total \\
\hline 2360 (\#8 sieve) & 488.38 & 488.38 & 0.00 & 0.00 & 0.00 & 100.00 \\
$1180(\# 16$ sieve) & 463.01 & 463.70 & 0.69 & 1.81 & 1.84 & 98.16 \\
$850(\# 20$ sieve) & 430.11 & 431.66 & 1.55 & 4.07 & 4.14 & 94.02 \\
500 (\#35 sieve) & 404.20 & 407.73 & 3.53 & 9.26 & 9.43 & 84.58 \\
250 (\#60 sieve) & 363.96 & 370.62 & 6.66 & 17.48 & 17.79 & 66.79 \\
$125(\# 120$ sieve) & 310.04 & 317.08 & 7.04 & 18.47 & 18.81 & 47.98 \\
63 (\#230 sieve) & 306.75 & 311.70 & 4.95 & 12.99 & 13.22 & 34.76 \\
$<63$ & & & 13.01 & 34.14 & 34.76 & 34.76 \\
Sample Lost & & & 0.68 & 1.78 & & \\
Total & & & & 98.22 & 100.00 & \\
\hline
\end{tabular}


Table A-2.2. Hydrometer Analysis: Trial 2

Particle Size Analysis $>>$ Sieve Analysis of Hydrometer Method: > No. 230 Sieve Trial 2 By: Maren Henley

Sample Name: NTS Area $3<$ No. 10 Standard U.S. Sieve

Mass of Transfer Beaker: $10 \mathrm{~g}$

Mass of Wet Soil and Beaker: $50 \mathrm{~g}$

Mass of Wet Soil: $40 \mathrm{~g}$

Adjusted Dry Mass of Soil: $38.11 \mathrm{~g}$

\begin{tabular}{ccccc}
\hline Time (min) & $\begin{array}{c}\text { Blank Hydrometer } \\
\text { Reading }\end{array}$ & $\begin{array}{c}\text { Blank Solution } \\
\text { Temperature }{ }^{\circ} \mathrm{C}\end{array}$ & $\begin{array}{c}\text { Soil Hydrometer } \\
\text { Reading }\end{array}$ & $\begin{array}{c}\text { Soil Solution } \\
\text { Temperature }\end{array}{ }^{\circ} \mathrm{C}$ \\
\hline 0.5 & 5.0 & 20.5 & 15.0 & 20.5 \\
1 & 5.0 & 20.5 & 14.5 & 20.5 \\
3 & 5.0 & 20.5 & 13.5 & 20.5 \\
10 & 5.5 & 20.5 & 12.5 & 20.5 \\
30 & 6.0 & 20.9 & 12.0 & 20.9 \\
60 & 5.0 & 21.2 & 11.0 & 21.2 \\
90 & 5.0 & 21.5 & 10.9 & 21.5 \\
120 & 4.5 & 21.6 & 10.8 & 21.6 \\
1440 & 5.0 & 21.9 & 8.8 & 21.9 \\
\hline
\end{tabular}

Mass of Transfer Beaker: $12.25 \mathrm{~g}$

Mass of Beaker and Sand: $37.79 \mathrm{~g}$

Mass of Sand: $25.54 \mathrm{~g}$

Mass of Clay and Silt: $12.57 \mathrm{~g}$

\begin{tabular}{lcccccc}
\hline $\begin{array}{l}\text { Sieve Size } \\
\text { (micrometer) }\end{array}$ & $\begin{array}{c}\text { Sieve } \\
\text { Mass } \\
(\mathrm{g})\end{array}$ & $\begin{array}{c}\text { Sieve and } \\
\text { Soil Mass } \\
(\mathrm{g})\end{array}$ & $\begin{array}{c}\text { Soil } \\
\text { Fraction } \\
\text { Mass }(\mathrm{g})\end{array}$ & $\begin{array}{c}\text { \% of } \\
\text { Sample }\end{array}$ & $\begin{array}{c}\text { \% Sample } \\
\text { Adjusted for } \\
\text { Sample Loss }\end{array}$ & \% Total \\
\hline 2360 (\#8 sieve) & 488.38 & 488.38 & 0.00 & 0.00 & 0.00 & 100.00 \\
1180 (\#16 sieve) & 462.96 & 464.10 & 1.14 & 2.99 & 3.03 & 96.97 \\
850 (\#20 sieve) & 430.03 & 432.00 & 1.97 & 5.17 & 5.24 & 91.72 \\
500 (\#35 sieve) & 404.07 & 408.05 & 3.98 & 10.44 & 10.59 & 81.13 \\
250 (\#60 sieve) & 363.92 & 370.51 & 6.59 & 17.29 & 17.54 & 63.60 \\
125 (\#120 sieve) & 310.08 & 316.84 & 6.76 & 17.74 & 17.99 & 45.61 \\
63 (\#230 sieve) & 306.71 & 311.28 & 4.57 & 11.99 & 12.16 & 33.45 \\
$<63$ & & & 12.57 & 32.98 & 33.45 & 33.45 \\
Sample Lost & & & 0.53 & 1.39 & & \\
Total & & & & 98.61 & 100.00 & \\
\hline
\end{tabular}


Table A-2.3. Hydrometer Analysis: Trial 3

Particle Size Analysis $\rightarrow$ Sieve Analysis of Hydrometer Method: $>$ No. 230 Sieve Trial 3 By: Maren Henley

Sample Name: NTS Area $3<$ No. 10 Standard U.S. Sieve

Mass of Transfer Beaker: $10 \mathrm{~g}$ Mass of Wet Soil and Beaker: $50 \mathrm{~g}$ Mass of Wet Soil: $40 \mathrm{~g}$ Adjusted Dry Mass of Soil: $38.11 \mathrm{~g}$

\begin{tabular}{ccccc}
\hline Time (min) & $\begin{array}{c}\text { Blank Hydrometer } \\
\text { Reading }\end{array}$ & $\begin{array}{c}\text { Blank Solution } \\
\text { Temperature }{ }^{\circ} \mathrm{C}\end{array}$ & $\begin{array}{c}\text { Soil Hydrometer } \\
\text { Reading }\end{array}$ & $\begin{array}{c}\text { Soil Solution } \\
\text { Temperature }{ }^{\circ} \mathrm{C}\end{array}$ \\
\hline 0.5 & 5.8 & 18.8 & 18.0 & 18.8 \\
1 & 6.0 & 18.9 & 18.0 & 18.9 \\
3 & 6.0 & 19.1 & 16.2 & 19.1 \\
10 & 5.5 & 19.5 & 13.8 & 19.5 \\
30 & 5.0 & 19.7 & 13.0 & 19.7 \\
60 & 6.0 & 20.1 & 13.0 & 20.1 \\
90 & 5.5 & 20.4 & 12.0 & 20.4 \\
120 & 5.8 & 20.7 & 11.2 & 20.7 \\
1440 & 4.8 & 24.3 & 8.0 & 24.3 \\
\hline
\end{tabular}

Mass of Transfer Beaker: $12.46 \mathrm{~g}$ Mass of Beaker and Sand: $37.37 \mathrm{~g}$ Mass of Sand: $24.91 \mathrm{~g}$ Mass of Clay and Silt: $13.2 \mathrm{~g}$

\begin{tabular}{lcccccc}
\hline $\begin{array}{l}\text { Sieve Size } \\
\text { (micrometer) }\end{array}$ & $\begin{array}{c}\text { Sieve } \\
\text { Mass } \\
(\mathrm{g})\end{array}$ & $\begin{array}{c}\text { Sieve and } \\
\text { Soil Mass } \\
(\mathrm{g})\end{array}$ & $\begin{array}{c}\text { Soil } \\
\text { Fraction } \\
\text { Mass (g) }\end{array}$ & $\begin{array}{c}\text { \% of } \\
\text { Sample }\end{array}$ & $\begin{array}{c}\text { \% Sample } \\
\text { Adjusted for } \\
\text { Sample Loss }\end{array}$ & \% Total \\
\hline 2360 (\#8 sieve) & 488.28 & 488.28 & 0.00 & 0.00 & 0.00 & 100.00 \\
1180 (\#16 sieve) & 462.90 & 463.52 & 0.62 & 1.63 & 1.66 & 98.34 \\
850 (\#20 sieve) & 430.36 & 431.59 & 1.23 & 3.23 & 3.30 & 95.03 \\
500 (\#35 sieve) & 404.08 & 407.85 & 3.77 & 9.89 & 10.12 & 84.91 \\
250 (\#60 sieve) & 363.77 & 370.65 & 6.88 & 18.05 & 18.47 & 66.44 \\
125 (\#120 sieve) & 309.95 & 316.82 & 6.87 & 18.03 & 18.44 & 48.00 \\
63 (\#230 sieve) & 306.07 & 310.75 & 4.68 & 12.28 & 12.56 & 35.44 \\
$<63$ & & & 13.20 & 34.64 & 35.44 & 35.44 \\
Sample Lost & & & 0.86 & 2.26 & & \\
Total & & & & 97.74 & 100.00 & \\
\hline
\end{tabular}


Table A-3.1. Hydrometer Analysis for $<0.063 \mathrm{~mm}$ : Trial 1

Particle Size Analysis -> Hydrometer Method: $<0.063 \mathrm{~mm}$ Sieve

Trial 1 By: Maren Henley

Spec. Grav.: 2.48

Dry Weight: $38.11 \mathrm{~g}$

\begin{tabular}{|c|c|c|c|c|c|c|c|c|c|}
\hline $\begin{array}{l}\text { Time } \\
\text { (min) }\end{array}$ & $\begin{array}{c}\text { Blank } \\
\text { Hydrometer } \\
\text { Reading }\end{array}$ & $\begin{array}{c}\text { Blank Solution } \\
\text { Temperature } \\
{ }^{\circ} \mathrm{C}\end{array}$ & $\begin{array}{c}\text { Soil } \\
\text { Hydrometer } \\
\text { Reading }\end{array}$ & $\begin{array}{l}\text { Constant for } \\
\text { Temperature }\end{array}$ & $\begin{array}{l}\text { Effective } \\
\text { Depth }\end{array}$ & $\begin{array}{c}\text { Difference in } \\
\text { Hydrometer } \\
\text { Readings }\end{array}$ & $\begin{array}{c}\text { Percentage } \\
\text { Finer for } \\
\text { Sample }\end{array}$ & $\begin{array}{l}\text { Diameter } \\
\text { of Particle } \\
\text { (mm) }\end{array}$ & $\begin{array}{c}\text { Cumulative } \\
\text { \% Finer }\end{array}$ \\
\hline 0.5 & 6.0 & 20.2 & 17.0 & 0.01431 & 13.5 & 11.0 & 29.73 & $7.44 \mathrm{E}-02$ & 19.50 \\
\hline 1 & 6.0 & 20.2 & 16.0 & 0.01431 & 13.7 & 10.0 & 27.03 & $5.30 \mathrm{E}-02$ & 17.73 \\
\hline 3 & 6.0 & 20.3 & 14.5 & 0.01431 & 13.9 & 8.5 & 22.97 & $3.08 \mathrm{E}-02$ & 15.07 \\
\hline 10 & 6.0 & 20.4 & 13.5 & 0.01431 & 14.1 & 7.5 & 20.27 & $1.70 \mathrm{E}-02$ & 13.30 \\
\hline 30 & 6.0 & 20.7 & 12.0 & 0.01414 & 14.3 & 6.0 & 16.22 & $9.76 \mathrm{E}-03$ & 10.64 \\
\hline 60 & 6.0 & 21.0 & 11.5 & 0.01414 & 14.4 & 5.5 & 14.86 & $6.93 E-03$ & 9.75 \\
\hline 90 & 6.0 & 21.3 & 11.0 & 0.01414 & 14.5 & 5.0 & 13.51 & $5.68 \mathrm{E}-03$ & 8.86 \\
\hline 120 & 5.5 & 21.5 & 10.9 & 0.01437 & 14.5 & 5.4 & 14.59 & $5.00 \mathrm{E}-03$ & 9.57 \\
\hline 1440 & 6.0 & 21.8 & 9.0 & 0.01437 & 14.8 & 3.0 & 8.11 & $1.46 \mathrm{E}-03$ & 5.32 \\
\hline
\end{tabular}


Table A-3.2. Hydrometer Analysis for $<0.063 \mathrm{~mm}$ : Trial 2

Particle Size Analysis $->$ Hydrometer Method: $<0.063 \mathrm{~mm}$ Sieve

Trial 2 By: Maren Henley

Spec. Grav.: 2.48

Dry Weight: $38.11 \mathrm{~g}$

\begin{tabular}{|c|c|c|c|c|c|c|c|c|c|}
\hline $\begin{array}{l}\text { Time } \\
(\min )\end{array}$ & $\begin{array}{c}\text { Blank } \\
\text { Hydrometer } \\
\text { Reading }\end{array}$ & $\begin{array}{c}\text { Blank Solution } \\
\text { Temperature } \\
{ }^{\circ} \mathrm{C}\end{array}$ & $\begin{array}{c}\text { Soil } \\
\text { Hydrometer } \\
\text { Reading }\end{array}$ & $\begin{array}{l}\text { Constant for } \\
\text { Temperature }\end{array}$ & $\begin{array}{l}\text { Effective } \\
\text { Depth }\end{array}$ & $\begin{array}{c}\text { Difference in } \\
\text { Hydrometer } \\
\text { Readings }\end{array}$ & $\begin{array}{l}\text { Percentage } \\
\text { Finer for } \\
\text { Sample }\end{array}$ & $\begin{array}{c}\text { Diameter } \\
\text { of Particle } \\
(\mathrm{mm})\end{array}$ & $\begin{array}{l}\text { Cumulative } \\
\text { \% Finer }\end{array}$ \\
\hline 0.5 & 5.0 & 20.5 & 15.0 & 0.01414 & 13.8 & 10.0 & 27.03 & $7.43 E-02$ & 17.73 \\
\hline 1 & 5.0 & 20.5 & 14.5 & 0.01414 & 13.9 & 9.5 & 25.68 & $5.27 \mathrm{E}-02$ & 16.84 \\
\hline 3 & 5.0 & 20.5 & 13.5 & 0.01414 & 14.1 & 8.5 & 22.97 & $3.07 \mathrm{E}-02$ & 15.07 \\
\hline 10 & 5.5 & 20.5 & 12.5 & 0.01414 & 14.2 & 7.0 & 18.92 & $1.68 \mathrm{E}-02$ & 12.41 \\
\hline 30 & 6.0 & 20.9 & 12.0 & 0.01414 & 14.3 & 6.0 & 16.22 & $9.76 \mathrm{E}-03$ & 10.64 \\
\hline 60 & 5.0 & 21.2 & 11.0 & 0.01414 & 14.5 & 6.0 & 16.22 & $6.95 \mathrm{E}-03$ & 10.64 \\
\hline 90 & 5.0 & 21.5 & 10.9 & 0.01397 & 14.5 & 5.9 & 15.95 & $5.61 \mathrm{E}-03$ & 10.46 \\
\hline 120 & 4.5 & 21.6 & 10.8 & 0.01397 & 14.5 & 6.3 & 17.03 & $4.86 \mathrm{E}-03$ & 11.17 \\
\hline 1440 & 5.0 & 21.9 & 8.8 & 0.01397 & 14.8 & 3.8 & 10.27 & $1.42 \mathrm{E}-03$ & 6.74 \\
\hline
\end{tabular}


Table A-3.3. Hydrometer Analysis for $<0.063 \mathrm{~mm}$ : Trial 3

Particle Size Analysis $\rightarrow$ Hydrometer Method: $<0.063 \mathrm{~mm}$ Sieve

Trial 3 By: Maren Henley

Spec. Grav.: 2.48

Dry Weight: $38.11 \mathrm{~g}$

\begin{tabular}{|c|c|c|c|c|c|c|c|c|c|}
\hline $\begin{array}{l}\text { Time } \\
\text { (min) }\end{array}$ & $\begin{array}{c}\text { Blank } \\
\text { Hydrometer } \\
\text { Reading }\end{array}$ & $\begin{array}{c}\text { Blank Solution } \\
\text { Temperature } \\
{ }^{\circ} \mathrm{C}\end{array}$ & $\begin{array}{c}\text { Soil } \\
\text { Hydrometer } \\
\text { Reading }\end{array}$ & $\begin{array}{l}\text { Constant for } \\
\text { Temperature }\end{array}$ & $\begin{array}{l}\text { Effective } \\
\text { Depth }\end{array}$ & $\begin{array}{c}\text { Difference in } \\
\text { Hydrometer } \\
\text { Readings }\end{array}$ & $\begin{array}{l}\text { Percentage } \\
\text { Finer for } \\
\text { Sample }\end{array}$ & $\begin{array}{c}\text { Diameter } \\
\text { of Particle } \\
\text { (mm) }\end{array}$ & $\begin{array}{l}\text { Cumulative } \\
\text { \% Finer }\end{array}$ \\
\hline 0.5 & 5.8 & 18.8 & 18.0 & 0.01449 & 13.3 & 12.2 & 32.97 & $7.47 \mathrm{E}-02$ & 21.63 \\
\hline 1 & 6.0 & 18.9 & 18.0 & 0.01449 & 13.3 & 12.0 & 32.43 & $5.28 \mathrm{E}-02$ & 21.28 \\
\hline 3 & 6.0 & 19.1 & 16.2 & 0.01449 & 13.7 & 10.2 & 27.57 & $3.10 \mathrm{E}-02$ & 18.08 \\
\hline 10 & 5.5 & 19.5 & 13.8 & 0.01431 & 14.0 & 8.3 & 22.43 & $1.69 \mathrm{E}-02$ & 14.72 \\
\hline 30 & 5.0 & 19.7 & 13.0 & 0.01431 & 14.2 & 8.0 & 21.62 & $9.85 \mathrm{E}-03$ & 14.18 \\
\hline 60 & 6.0 & 20.1 & 13.0 & 0.01431 & 14.2 & 7.0 & 18.92 & $6.96 \mathrm{E}-03$ & 12.41 \\
\hline 90 & 5.5 & 20.4 & 12.0 & 0.01431 & 14.3 & 6.5 & 17.57 & $5.70 \mathrm{E}-03$ & 11.52 \\
\hline 120 & 5.8 & 20.7 & 11.2 & 0.01414 & 14.5 & 5.4 & 14.59 & 4.92E-03 & 9.57 \\
\hline 1440 & 4.8 & 24.3 & 8.0 & 0.01365 & 15.0 & 3.2 & 8.65 & $1.39 \mathrm{E}-03$ & 5.67 \\
\hline
\end{tabular}


Table A-4. Normalized Cumulative \% Finer for $0.063 \mathrm{~mm}-2.36 \mathrm{~mm}$ Sieve

Particle Size Analysis $\rightarrow$ Hydrometer $>$ No. 230 Sieve Results By: Maren Henley

\begin{tabular}{lccccc}
\hline $\begin{array}{l}\text { Sieve Size } \\
\text { (micrometer) }\end{array}$ & $\begin{array}{c}\text { \% Finer } \\
\text { Trial 1 }\end{array}$ & $\begin{array}{c}\text { \% Finer } \\
\text { Trial 2 }\end{array}$ & $\begin{array}{c}\text { \% Finer } \\
\text { Trial 3 }\end{array}$ & $\begin{array}{c}\text { \% Finer } \\
\text { Average }\end{array}$ & $\begin{array}{c}\text { Cumulative } \\
\text { \% Finer }\end{array}$ \\
\hline 2360 (\#8 sieve) & 100.00 & 100.00 & 100.00 & 100.00 & 65.60 \\
1180 (\#16 sieve) & 98.16 & 96.97 & 98.34 & 97.82 & 64.17 \\
850 (\#20 sieve) & 94.02 & 91.72 & 95.03 & 93.59 & 61.40 \\
500 (\#35 sieve) & 84.59 & 81.13 & 84.91 & 83.54 & 54.80 \\
250 (\#60 sieve) & 66.79 & 63.60 & 66.44 & 65.61 & 43.04 \\
125 (\#120 sieve) & 47.98 & 45.61 & 48.00 & 47.20 & 30.96 \\
63 (\#230 sieve) & 34.76 & 33.45 & 35.44 & 34.55 & 22.66 \\
$<63$ & 34.76 & 33.45 & 35.44 & 34.55 & 22.66 \\
\hline
\end{tabular}

Table A-5. Normalized Cumulative \% Finer for $<0.063 \mathrm{~mm}$

Particle Size Analysis $->$ Hydrometer $>$ No. 230 Sieve Results By: Maren Henley

\begin{tabular}{lccccc}
\hline $\begin{array}{l}\text { Diameter of } \\
\text { Particle }(\mathrm{mm})\end{array}$ & $\begin{array}{c}\text { \% Finer } \\
\text { Trial 1 }\end{array}$ & $\begin{array}{c}\text { \% Finer } \\
\text { Trial 2 }\end{array}$ & $\begin{array}{c}\text { \% Finer } \\
\text { Trial 3 }\end{array}$ & $\begin{array}{c}\text { \% Finer } \\
\text { Average }\end{array}$ & $\begin{array}{c}\text { Cumulative } \\
\text { \% Finer }\end{array}$ \\
\hline $7.45 \mathrm{E}-02$ & 29.73 & 27.03 & 32.97 & 29.91 & 19.62 \\
$5.28 \mathrm{E}-02$ & 27.03 & 25.68 & 32.43 & 28.38 & 18.62 \\
$3.08 \mathrm{E}-02$ & 22.97 & 22.97 & 27.57 & 24.50 & 16.07 \\
$1.69 \mathrm{E}-02$ & 20.27 & 18.92 & 22.43 & 20.54 & 13.47 \\
$9.79 \mathrm{E}-03$ & 16.22 & 16.22 & 21.62 & 18.02 & 11.82 \\
$6.95 \mathrm{E}-03$ & 14.86 & 16.22 & 18.92 & 16.67 & 10.93 \\
$5.66 \mathrm{E}-03$ & 13.51 & 15.95 & 17.57 & 15.68 & 10.28 \\
$4.92 \mathrm{E}-03$ & 14.59 & 17.03 & 14.59 & 15.41 & 10.11 \\
$1.42 \mathrm{E}-03$ & 8.11 & 10.27 & 8.65 & 9.01 & 5.91 \\
\hline
\end{tabular}




\section{Appendix B}

Modified Proctor Compaction Test Data 
Table B-1. Modified Proctor Compaction Test: $<2 \mathrm{~mm}$ Sieve

Modified Proctor Compaction Test (layering) NTS Area 3 minus - 2 mm

Date: 6/25/97 By: Maren Henley

\begin{tabular}{lcccc}
\hline Treatment & 1 & 2 & 3 & 4 \\
\hline $\begin{array}{l}\text { Moisture content to be } \\
\text { added (g/g * 100) }\end{array}$ & $2 \%$ & $4 \%$ & $6 \%$ & $8 \%$ \\
Mold + wet soil (g) & 3805 & 3907 & 3981 & 3927 \\
Mold (g) & 2004 & 2004 & 2004 & 2004 \\
Wet soil (g) & 1801 & 1903 & 1977 & 1923 \\
Factor * & 0.0662 & 0.0662 & 0.0662 & 0.0662 \\
Wet density (g/cm $\left.{ }^{3}\right)$ & 1.91 & 2.02 & 2.10 & 2.04 \\
Pan + wet soil (g) & 724 & 790 & 806 & 759 \\
Pan + dry soil (g) & 680 & 727 & 733 & 682 \\
Moisture loss (g) & 44 & 63 & 73 & 77 \\
Pan (g) & 201 & 203 & 203 & 201 \\
Dry soil (g) & 479 & 524 & 530 & 481 \\
Final moisture content & $9.2 \%$ & $12.0 \%$ & $13.8 \%$ & $16.0 \%$ \\
(g/g * 100) & & & 1.84 & 1.76 \\
Dry density (g/cm $\left.{ }^{3}\right)$ & 1.75 & & & \\
\hline
\end{tabular}


Table B-2. Modified Proctor Compaction Test: $<5 \mathrm{~mm}$ Sieve

Modified Proctor Compaction Test (layering) NTS Area 3 minus - $5 \mathrm{~mm}$

Date: 6/25/97 By: Maren Henley

\begin{tabular}{lcccc}
\hline Treatment & 1 & 2 & 3 & 4 \\
\hline $\begin{array}{l}\text { Moisture content to be } \\
\text { added (g/g * 100) }\end{array}$ & $2 \%$ & $4 \%$ & $6 \%$ & $8 \%$ \\
Mold + wet soil (g) & 3841 & 3936 & 3968 & 3929 \\
Mold (g) & 2004 & 2009 & 2004 & 2004 \\
Wet soil (g) & 1837 & 1927 & 1964 & 1925 \\
Factor * & 0.0662 & 0.0662 & 0.0662 & 0.0662 \\
Wet density (g/cm $\left.{ }^{3}\right)$ & 1.95 & 2.04 & 2.08 & 2.04 \\
Pan + wet soil (g) & 773 & 790 & 732 & 842 \\
Pan + dry soil (g) & 723 & 728 & 669 & 754 \\
Moisture loss (g) & 50 & 62 & 63 & 88 \\
Pan (g) & 207 & 205 & 204 & 207 \\
Dry soil (g) & 516 & 523 & 465 & 547 \\
Final moisture content & $9.7 \%$ & $11.9 \%$ & $13.5 \%$ & $16.1 \%$ \\
(g/g * 100) & & & & \\
Dry density (g/cm & & 1.83 & 1.83 & 1.76 \\
\hline
\end{tabular}




\section{Appendix C}

Saturated Hydraulic Conductivity Data 
Table C-1. Saturated Hydraulic Conductivities

NTS Area 3 Saturated Hydraulic Conductivities

Date: 6/27/97 By: Maren Henley

\begin{tabular}{lccccccccccc}
\hline $\begin{array}{l}\text { Size Fraction- } \\
\text { Compaction }\end{array}$ & $\begin{array}{c}\text { Diameter } \\
(\mathrm{m})\end{array}$ & $\begin{array}{c}\text { Length } \\
(\mathrm{m})\end{array}$ & $\begin{array}{c}\text { Head } \\
\text { Initial } \\
(\mathrm{m})\end{array}$ & $\begin{array}{c}\text { Head }- \\
\text { Final } \\
(\mathrm{m})\end{array}$ & $\begin{array}{c}\text { Flow } \\
\text { Volume } \\
\left(\mathrm{m}^{3}\right)\end{array}$ & $\begin{array}{c}\mathrm{T}_{1} \\
(\mathrm{sec})\end{array}$ & $\begin{array}{c}\mathrm{T}_{2} \\
(\mathrm{sec})\end{array}$ & $\begin{array}{c}\mathrm{T}_{3} \\
(\mathrm{sec})\end{array}$ & $\begin{array}{c}\mathrm{T}_{4} \\
(\mathrm{sec})\end{array}$ & $\begin{array}{c}\mathrm{T}_{5} \\
(\mathrm{sec})\end{array}$ & $\mathrm{K}_{\text {sat }}(\mathrm{m} / \mathrm{s})$ \\
\hline 5 to $2 \mathrm{~mm}-\mathrm{NA}$ & $8.31 \mathrm{E}-02$ & $7.55 \mathrm{E}-02$ & 0.674 & 0.678 & $1.00 \mathrm{E}-04$ & 67 & 67 & 67 & 65 & 68 & $5.21 \mathrm{E}-03$ \\
5 to $2 \mathrm{~mm}-\mathrm{NA}$ & $8.28 \mathrm{E}-02$ & $7.54 \mathrm{E}-02$ & 0.696 & 0.698 & $1.00 \mathrm{E}-04$ & 156 & 156 & 164 & 167 & 158 & $4.37 \mathrm{E}-03$ \\
$<5 \mathrm{~mm}-90 \%$ & $8.28 \mathrm{E}-02$ & $7.51 \mathrm{E}-02$ & 0.590 & 0.712 & $2.50 \mathrm{E}-05$ & 530 & 515 & 503 & 509 & 514 & $5.56 \mathrm{E}-06$ \\
$<5 \mathrm{~mm}-90 \%$ & $8.27 \mathrm{E}-02$ & $7.53 \mathrm{E}-02$ & 0.727 & 0.758 & $2.50 \mathrm{E}-05$ & 489 & 512 & 512 & 506 & 496 & $2.25 \mathrm{E}-05$ \\
$<5 \mathrm{~mm}-90 \%$ & $8.27 \mathrm{E}-02$ & $7.53 \mathrm{E}-02$ & 0.632 & 0.758 & $2.50 \mathrm{E}-05$ & 136 & 140 & 137 & 137 & 139 & $2.02 \mathrm{E}-05$ \\
$<5 \mathrm{~mm}-90 \%$ & $8.29 \mathrm{E}-02$ & $7.55 \mathrm{E}-02$ & 0.480 & 0.660 & $2.00 \mathrm{E}-05$ & 697 & 751 & 732 & 763 & 760 & $2.10 \mathrm{E}-06$ \\
$<5 \mathrm{~mm}-83 \%$ & $8.25 \mathrm{E}-02$ & $7.54 \mathrm{E}-02$ & 0.679 & 0.690 & $2.00 \mathrm{E}-05$ & 312 & 332 & 329 & 331 & 320 & $7.90 \mathrm{E}-05$ \\
$<5 \mathrm{~mm}-83 \%$ & $8.24 \mathrm{E}-02$ & $7.56 \mathrm{E}-02$ & 0.651 & 0.740 & $2.50 \mathrm{E}-05$ & 199 & 204 & 199 & 201 & 200 & $1.99 \mathrm{E}-05$ \\
$<5 \mathrm{~mm}-83 \%$ & $8.24 \mathrm{E}-02$ & $7.56 \mathrm{E}-02$ & 0.650 & 0.665 & $2.00 \mathrm{E}-05$ & 692 & 705 & 707 & 686 & 656 & $2.74 \mathrm{E}-05$ \\
$<2 \mathrm{~mm}-90 \%$ & $8.27 \mathrm{E}-02$ & $7.55 \mathrm{E}-02$ & 0.077 & 0.681 & $1.00 \mathrm{E}-05$ & 525 & 544 & 579 & 643 & 675 & $3.92 \mathrm{E}-07$ \\
$<2 \mathrm{~mm}-90 \%$ & $8.25 \mathrm{E}-02$ & $7.53 \mathrm{E}-02$ & 0.120 & 0.665 & $1.50 \mathrm{E}-05$ & 409 & 421 & 428 & 442 & 453 & $9.00 \mathrm{E}-07$ \\
$<2 \mathrm{~mm}-83 \%$ & $8.27 \mathrm{E}-02$ & $7.55 \mathrm{E}-02$ & 0.619 & 0.728 & $2.50 \mathrm{E}-05$ & 353 & 377 & 358 & 361 & 361 & $8.91 \mathrm{E}-06$ \\
$<2 \mathrm{~mm}-83 \%$ & $8.27 \mathrm{E}-02$ & $7.55 \mathrm{E}-02$ & 0.680 & 0.728 & $1.00 \mathrm{E}-05$ & 284 & 283 & 298 & 298 & 292 & $1.01 \mathrm{E}-05$ \\
$<2 \mathrm{~mm}-83 \%$ & $8.27 \mathrm{E}-02$ & $7.55 \mathrm{E}-02$ & 0.674 & 0.750 & $2.50 \mathrm{E}-05$ & 430 & 447 & 443 & 437 & 429 & $1.06 \mathrm{E}-05$ \\
\hline
\end{tabular}


Appendix D

\section{Water Retention Data}


Table D-1. Water Retention Data

Water Retention Data from Maren Henley - Area 3

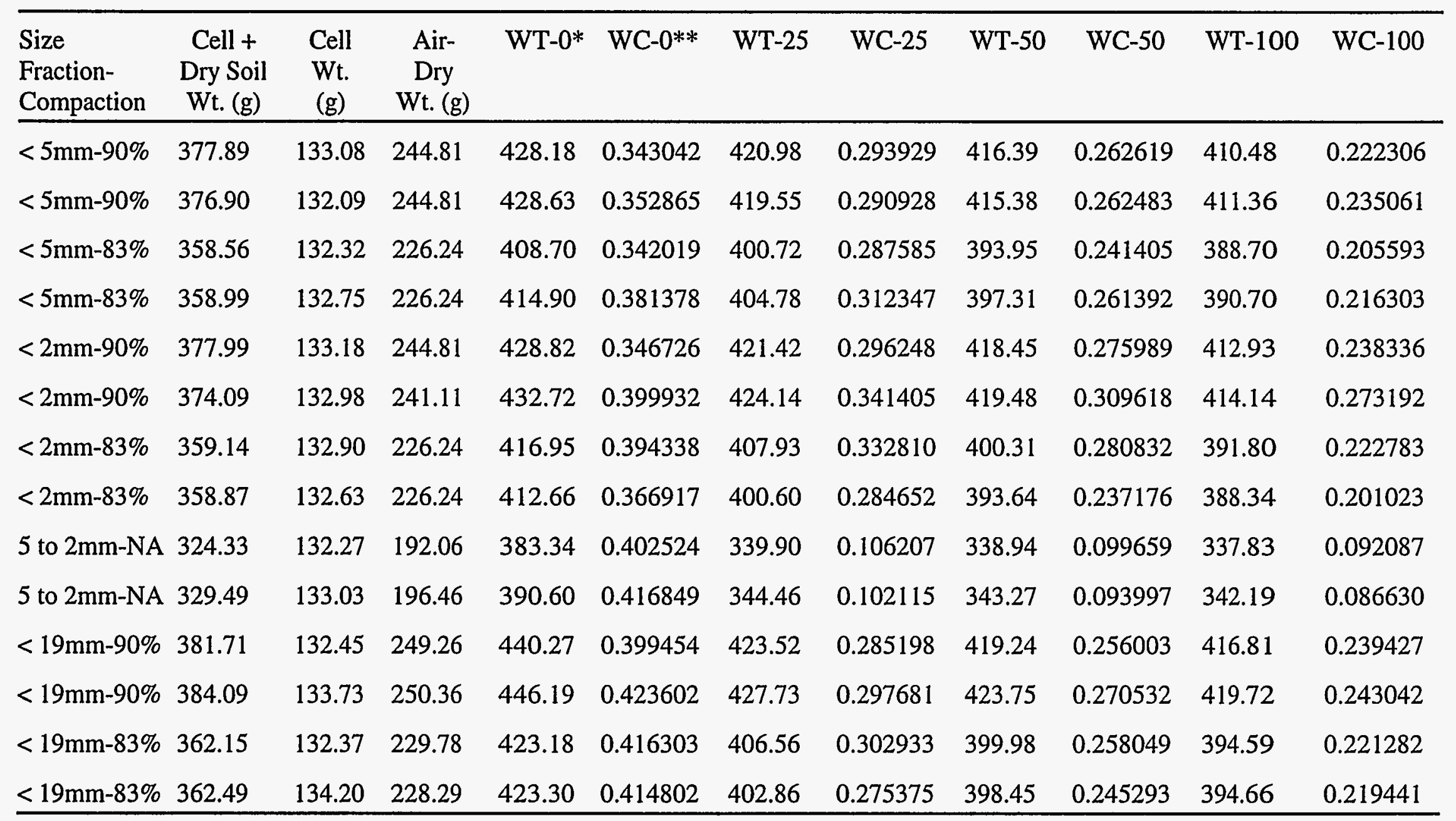

$* \mathrm{WT}=$ weight $(\mathrm{g})$ at designated tension $(\mathrm{cm})$

** $\mathrm{WC}=$ water content by volume (\%) 
Table D-1. Water Retention Data (Continued)

Water Retention Data from Maren Henley - Area 3 (Continued)

\begin{tabular}{llllllllllll}
\hline $\begin{array}{l}\text { Size Fraction- } \\
\text { Compaction }\end{array}$ & WT-150 & WC-150 & WT-200 & WC-200 & WT-500 & WC-500 & WT-750 & WC-750 & WT-1000 & WC-1000 \\
\hline$<5 \mathrm{~mm}-90 \%$ & 408.12 & 0.206207 & 406.22 & 0.193247 & 404.85 & 0.183902 & 404.00 & 0.178104 & 403.31 & 0.173397 \\
$<5 \mathrm{~mm}-90 \%$ & 410.02 & 0.225921 & 408.82 & 0.217735 & 406.87 & 0.204434 & 405.72 & 0.196589 & 405.13 & 0.192565 \\
$<5 \mathrm{~mm}-83 \%$ & 386.92 & 0.193452 & 386.10 & 0.187858 & 384.40 & 0.176262 & 383.51 & 0.170191 & 382.63 & 0.164188 \\
$<5 \mathrm{~mm}-83 \%$ & 389.13 & 0.205593 & 387.90 & 0.197203 & 385.61 & 0.181583 & 384.35 & 0.172988 & 383.79 & 0.169168 \\
$<2 \mathrm{~mm}-90 \%$ & 409.85 & 0.217326 & 408.62 & 0.208936 & 405.99 & 0.190996 & 405.07 & 0.184720 & 404.12 & 0.178240 \\
$<2 \mathrm{~mm}-90 \%$ & 410.74 & 0.250000 & 409.73 & 0.243111 & 407.11 & 0.225239 & 405.52 & 0.214393 & 404.10 & 0.204707 \\
$<2 \mathrm{~mm}-83 \%$ & 388.49 & 0.200205 & 387.23 & 0.191610 & 384.33 & 0.171828 & 383.32 & 0.164939 & 382.48 & 0.159209 \\
$<2 \mathrm{~mm}-83 \%$ & 387.03 & 0.192087 & 386.22 & 0.186562 & 384.24 & 0.173056 & 383.03 & 0.164802 & 382.42 & 0.160641 \\
5 to 2mm-NA & 337.48 & 0.089700 & 337.18 & 0.087653 & 337.04 & 0.086698 & 336.21 & 0.081037 & 335.78 & 0.078104 \\
5 to 2mm-NA & 341.19 & 0.079809 & 340.83 & 0.077353 & 340.61 & 0.075853 & 340.01 & 0.071760 & 339.58 & 0.068827 \\
$<19 \mathrm{~mm}-90 \%$ & 414.98 & 0.226944 & 414.07 & 0.220737 & 412.55 & 0.210368 & 411.28 & 0.201705 & 410.14 & 0.193929 \\
$<19 \mathrm{~mm}-90 \%$ & 417.75 & 0.229604 & 416.62 & 0.221896 & 414.86 & 0.209891 & 413.46 & 0.200341 & 412.42 & 0.193247 \\
$<19 \mathrm{~mm}-83 \%$ & 392.51 & 0.207094 & 391.75 & 0.201910 & 389.60 & 0.187244 & 388.34 & 0.178649 & 387.48 & 0.172783 \\
$<19 \mathrm{~mm}-83 \%$ & 393.01 & 0.208186 & 392.32 & 0.203479 & 392.23 & 0.202865 & 388.87 & 0.179945 & 387.87 & 0.173124 \\
\hline
\end{tabular}




\section{DISTRIBUTION}

Bob Bangerter

Environmental Restoration Division

Nevada Operations Office

U.S. Department of Energy

P.O. Box 98518

Las Vegas, NV 89193-8518

Warren D. Black

U.S. Department of Energy

EM-322, Trevion II Bldg.

1000 Independence Avenue SW

Washington D.C. 20585

Joanne M. Bradbery, Director

Contract Management Division

Nevada Operations Office

U.S. Department of Energy

P.O. Box 98518

Las Vegas, NV 89193-8518

John Cochran

GCD Project Leader

Sandia National Laboratories

P.O. Box 5800

Albuquerque, NM 87185-1345

Beverly Colbert

Contract Management Division

Nevada Operations Office

U.S. Department of Energy

P.O. Box 98518

Las Vegas, NV 89193-8518

Frank Di Sanza, Director

Energy Technologies Division

Nevada Operations Office

U.S. Department of Energy

P.O. Box 98518

Las Vegas, NV 89193-8518

Brian Dozier

Bechtel Nevada

P.O. Box 98521

Las Vegas, NV 89193-8521
Doug Duncan

Hydrology Program Manager

Environmental Protection Division

Nevada Operations Office

U.S. Department of Energy

P.O. Box 98518

Las Vegas, NV 89193-8518

David Gallegos

Sandia National Laboratories

Department 6331

P.O. Box 5800, M/S 1345

Albuquerque, NM 87185-1345

Carl P. Gertz, Acting Assisstant Manager

Environmental Management Office

Nevada Operations Office

U.S. Department of Energy

P.O. Box 98518

Las Vegas, NV 89193-8518

Joseph M. Ginanni

Waste Management Division

Nevada Operations Office

U.S. Department of Energy

P.O. Box 98518

Las Vegas, NV 89193-8518

John Izbicki

U.S. Geological Survey

5735 Kearny Villa Rd.

Suite O

San Diego, CA 92123

Kathy Izell

Assistant Manager for Technical Services

Nevada Operations Office

U.S. Department of Energy

P.O. Box 98518

Las Vegas, NV 89193-8518

Roger Jacobson

Desert Research Institute

Water Resources Center

P.O. Box 19040

Las Vegas, NV 89132-0040 
Marjory Jones

Desert Research Institute

Water Resources Center

P.O. Box 60220

Reno, NV 89506-0220

Jim Kannard

Bechtel Nevada

P.O. Box 98521

Las Vegas, NV 89193-8521

Randy Laczniak

U.S. Geological Survey

Water Resources Division

6770 S. Paradise Rd.

Las Vegas, NV 89119

Kevin Leary

Waste Management Division

Nevada Operations Office

U.S. Department of Energy

P.O. Box 98518

Las Vegas, NV 89193-8518

Steve Mellington, Director

Environmental Restoration Division

Nevada Operations Office

U.S. Department of Energy

P.O. Box 98518

Las Vegas, NV 89193-8518

Leslie A. Monroe

Environmental Protection Division

Nevada Operations Office

U.S. Department of Energy

P.O. Box 98518

Las Vegas, NV 89193-8518

Beth Moore

Waste Management Division

Nevada Operations Office

U.S. Department of Energy

P.O. Box 98518

Las Vegas, NV 89193-8518
Fred Penrod

Waste Management Division

Nevada Operations Office

U.S. Department of Energy

P.O. Box 98518

Las Vegas, NV 89193-8518

Stewart Rawlinson

Bechtel Nevada

P.O. Box 95487, M/S 580

Las Vegas, NV 89193-5487

Michael J. Sully

Bechtel Nevada

P.O. Box 98521 , M/S 966

Las Vegas, NV 89193-8521

Doug Trudeau

U.S. Geological Survey

Water Resources Division

6770 S. Paradise Rd.

Las Vegas, NV 89119

Wilhelm Wilborn

Energy Technologies Division

Nevada Operations Office

U.S. Department of Energy

P.O. Box 98518

Las Vegas, NV 89193-8518

Janet Wiley

International Technology Corporation

$4330 \mathrm{~S}$. Valley View

Suite 114

Las Vegas, NV 89103

Les Winnfield

Waste Management Division

Nevada Operations Office

U.S. Department of Energy

P.O. Box 98518

Las Vegas, NV 89193-8518

Annie Kelley

State Documents Department

Nevada State Library

Capitol Complex

Carson City, NV 89710

Archives

Getchell Library

University of Nevada, Reno 
Beverly Carter

MacKay School of Mines Library

University of Nevada, Reno

Document Section, Library

University of Nevada, Las Vegas

4505 Maryland Parkway

Las Vegas, NV 89154

Library (Stead)

Desert Research Institute

P.O. Box 60220

Reno, Nevada 89506-0220

Library

IT Corporation

Bldg. B-1

P.O. Box 93838, M/S 439

Las Vegas, NV 89193-3838

ATTN: Toni Miller
Library

Southem Nevada Science Center

Desert Research Institute

P.O. Box 19040

Las Vegas, NV 89132-0040

Librarian

Water Resources Center Archives

410 O'Brien Hall

University of California

Berkeley, CA 94720-1718

Public Reading Facility

Bechtel Nevada

P.O. Box 98521

Las Vegas, NV 89193-8521

Technical Information Resource Center

Nevada Operations Office

U.S. Department of Energy

P.O. Box 98518

Las Vegas, NV 89193-8518

Office of Scientific and Technical Information

U.S. Department of Energy

P.O. Box 62

Oak Ridge, TN 37831-9939 